\title{
NBSIR 87-3601
}

\section{High Temperature Chemistry of Stored Chemical Energy Reactions for Propulsion}

L. P. Cook. E. R. Plante, D. W. Bonnell, and J. W. Hastie

\section{U.S. DEPARTMENT OF COMMERCE}

National Bureau of Standards

Institute for Materials Science and Engineering

High Temperature Chemistry

Ceramics Division

Gaithersburg, MD 20899

July 1987

Annual Report

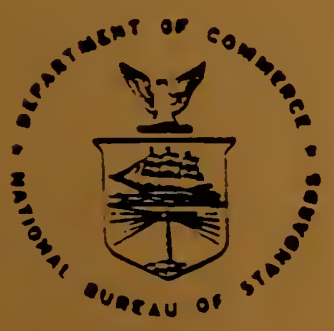

U.S. DEPARTMENT OF COMMERCE

NATIONAL BUREAU OF STANDARDS 



\title{
HIGH TEMPERATURE CHEMISTRY OF \\ STORED CHEMICAL ENERGY \\ REACTIONS FOR PROPULSION
}

L. P. Cook, E. R. Plante, D. W. Bonnell, and J. W. Hastie

\begin{abstract}
U.S. DEPARTMENT OF COMMERCE
National Bureau of Standards

Institute for Materials Science and Engineering

High Temperature Chemistry

Ceramics Division

Gaithersburg, MD 20899
\end{abstract}

June 1987

Annual Report

U.S. DEPARTMENT OF COMMERCE, Malcolm Baldrige, Secretary NATIONAL BUREAU OF STANDARDS. Emest Ambler, Diroctor 



\section{High Temperature Chemistry of Stored Chemical Energy Reactions for Propulsion}

Annual Report

For the Period May 25, 1985 to December 31, 1986

L. P. Cook, E. R. Plante, D. W. Bonnell, and J. W. Hastie

Ceramics Division

Institute for Materials Science and Engineering

National Bureau of Standards

Gaithersburg, MD 20899

March 25, 1986

\section{Prepared for the Department of the Navy \\ Office of Naval Research \\ Arlington, VA 22217}

Under Contract No: N00014-85-F-0144

APPROVED FOR PUBLIC RELEASE: DISTRIBUTION UNLIMITED

REPRODUCTION IN WHOLE OR IN PART IS PERMITTED FOR ANY PURPOSE OF THE U.S. GOVERNMENT 
HIGH TEMPERATURE CHEMISTRY OF STORED CHEMICAL ENERGY

REACTIONS FOR PROPULSION

Table of Contents

Abstract . . . . . . . . . . . . . . . . . . . . . . 3

I. INTRODUCTION . . . . . . . . . . . . . . . . . . . . . 4

II. REACTION VERIFICATION . . . . . . . . . . . . . . . . . . 6

A. Equilibrium Among Predicted Product Phases . . . . . . . . . . 6

B. $L I A l M g / \mathrm{ClO}_{3} \mathrm{~F}$. . . . . . . . . . . . . . . . . . . . . . . . 7

C. Thermal Decomposition of $\mathrm{ClO}_{3} \mathrm{~F}$. . . . . . . . . . . . . . . . 9

1. Coupling of the Thermoanalyzer with a Mass Spectrometer. . 9

11. Analysis of $\mathrm{ClO}_{3} \mathrm{~F}$ Decomposition Using High Pressure Sampling Transpiration Mass Spectrometry . . . . . . . . . . . 11

III. RINETICS . . . . . . . . . . . . . . . . . . . . . . . 14

A. Reaction of $\mathrm{Al}_{2} \mathrm{O}_{3}$ with $\mathrm{ClO}_{3} \mathrm{~F}$. . . . . . . . . . . . . . . 14

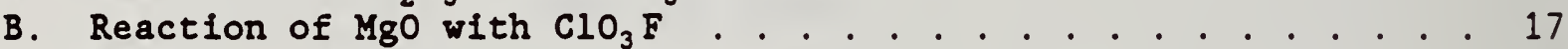

C. Reaction of $\mathrm{Mg}$ with $\mathrm{ClO}_{3} \mathrm{~F}$. . . . . . . . . . . . . . . . . . 18

D. Reaction of $\mathrm{Al}$ with $\mathrm{ClO}_{3} \mathrm{~F}$. . . . . . . . . . . . . . . . . . . 18

E. Transpiration Mass Spectrometry (TMS) of the $\mathrm{Al} / \mathrm{ClO}_{3}$ F Reaction. 21

IV. PHASE EQUILIBRIA . . . . . . . . . . . . . . . . . . . . 23

A. Condensed Phase Equilibria of the System $\mathrm{Li}_{2} \mathrm{O}-\mathrm{Al}_{2} \mathrm{O}_{3}$. . . . . . 23

i. Melting and Solid Solution Relations . . . . . . . . . . . 23

11. Solid State Transition in $\mathrm{LiAl}_{5} \mathrm{O}_{8}$ Spinel . . . . . . . . . 25

B. Condensed Phase Equilibria in the system $\mathrm{Li}_{2} \mathrm{O}-\mathrm{Al}_{2} \mathrm{O}_{3}-\mathrm{AlF}_{3}-\mathrm{LIF}$. 26

C. Thermodynamics of Competing Oxidation Reactions . . . . . . . . 27

D. Reactant/Product Vapor Pressures . . . . . . . . . . . . . 31

v. DISCUSSION AND FUTURE DIRECTIONS . . . . . . . . . . . . . . . . 32

VI. REFERENCES . . . . . . . . . . . . . . . . . . . . . 33

VIII. FIGURES. . . . . . . . . . . . . . . . . . . . . . . . 51

IX. DISTRIBUTION. . . . . . . . . . . . . . . . . . . . 53 


\section{HIGH TEMPERATURE CHEMISTRY OF STORED CHEMICAL ENERGY REACTIONS FOR PROPULSION}

\section{Abstract}

This report summarizes the results of a continuing study of the high temperature chemistry of stored chemical energy reaction systems. The eight fuel/oxidant reactions of interest (including several which are multistage) are: $\mathrm{Li} / \mathrm{H}_{2} \mathrm{O}, \mathrm{H}_{2} / \mathrm{O}_{2} ; \mathrm{Li} / \mathrm{H}_{2} \mathrm{O}, \mathrm{NaO}_{2} / \mathrm{H}_{2} \mathrm{O}, \mathrm{H}_{2} / \mathrm{O}_{2} ; \mathrm{MgAl} / \mathrm{H}_{2} \mathrm{O}, \mathrm{H}_{2} / \mathrm{O}_{2} ; \mathrm{LiAl} / \mathrm{ClO} \mathrm{F}_{3} \mathrm{~F}$; $\mathrm{LiAlMg} / \mathrm{ClO}_{3} \mathrm{~F} ; \mathrm{LiBe} / \mathrm{ClO}_{3} \mathrm{~F} ; \mathrm{Li} / \mathrm{C} / \mathrm{F}_{20} ; \mathrm{LiB} / \mathrm{NF}_{3}$. Thermodynamic prediction of the products of three of these reactions has been corroborated by equilibrating postulated products at high temperature, while results from a fourth reaction require modification of the reaction scheme originally proposed. Mass spectrometric observations on the thermal decomposition of $\mathrm{ClO}_{3} \mathrm{~F}$ at elevated temperatures are presented.

Thermogravimetric studies have been completed on the behavior of $\mathrm{Al}_{2} \mathrm{O}_{3}$ and $\mathrm{MgO}$ in the presence of $\mathrm{ClO}_{3} \mathrm{~F}$. Based on these data a new ceramic containment system comprised of alumina and magnesia parts has allowed extension of kinetic experiments from the $650^{\circ} \mathrm{C}$ limit previously encountered to a temperature in excess of $800^{\circ} \mathrm{C}$. Using the new apparatus, we have observed the relative inertness of the $\mathrm{Al}$ component of the fuel to oxidation by $\mathrm{ClO}_{3} \mathrm{~F}$ even at $800^{\circ} \mathrm{C}$. We have also noted the extensive vapor phase transport of IiF and $\mathrm{MgF}_{2}$, not expected on the basis of known thermodynamic data.

Thermogravimetric experiments have been completed on the oxidation of molten aluminum droplets by $\mathrm{ClO}_{3} \mathrm{~F}$. Rate data for this reaction indicate multiple mechanisms, possibly including the following steps: (1) nucleation and growth of $\mathrm{AlF}_{3}$ precipitation sites; (2) edge growth of $\mathrm{AlF}_{3}$ is lands followed by coalescence of islands; (3) diffusion limited thickening of the $\mathrm{AlF}_{3}$ layer. Observations on the early stages of the $\mathrm{Al} / \mathrm{ClO}_{3} \mathrm{~F}$ reaction have also been made using high pressure sampling transpiration mass spectrometry.

Phase equilibrium experiments have continued on the product system $\mathrm{Li}_{2} \mathrm{O}-\mathrm{Al}_{2} \mathrm{O}_{3}$ in sealed Mo capsules, utilizing an improved high temperature equilibration apparatus. Experiments indicate a previously undescribed degree of complexity near the high alumina end, which may involve solid solution of $\mathrm{Li}_{2} \mathrm{O}$ in the corundum structure, or an intermediate series of solid solutions or compounds based on the $\mathrm{LiAl}_{5} \mathrm{O}_{8}$ spinel phase. The solid state phase transition in $\mathrm{LiAl}_{5} \mathrm{O}_{8}$ has been studied by DTA; although the solid solution region is small, the temperature of this transition ranges from $1269^{\circ}$ to $1308^{\circ}$ depending on whether it is $\mathrm{Al}_{2} \mathrm{O}_{3}$-saturated or $\mathrm{Li}_{2} \mathrm{O}$-saturated. In the $\mathrm{ClO}_{3} \mathrm{~F}$-based reaction systems, substantial entry of fluorine into the product $\mathrm{LiAl}_{5} \mathrm{O}_{8}$ spinel phase is postulated.

Thermodynamic calculations have been completed to assess the importance of vaporization over reactant/product solids and liquids. In a situation where dissociated $\mathrm{ClO}_{3} \mathrm{~F}$ is flowing over molten alloys, fluoride products are thermodynamically most stable, followed by oxides, and finally by chlorides. The chlorides in general have high vapor pressures, which may be enhanced by 
polymerization. If passivating product layers of liquid or solid fluorides are formed on metal reactants during $\mathrm{ClO}_{3} \mathrm{~F}$ oxidation, it would be expected that chlorine and chlorides would be partitioned strongly into the vapor phase, along with oxygen.

Future work is plannæd which will determine rate constants and temperature dependencies for the kinetics of the oxidation of individual alloy components by $\mathrm{Cl}_{2}, \mathrm{O}_{2}$ and $\mathrm{F}_{2}$. Phase equilibrium determinations will focus on the system $\mathrm{Li}-\mathrm{Al}-\mathrm{Mg}-\mathrm{O}-\mathrm{F}$, with special regard to the entry of fluorine into oxide phases.

\section{INTRODUCTION}

The present report describes results of our research on the chemistry of liquid metal-based stored chemical energy propellants during the past year. This work represents a continuation of work begun earlier and described in two previous reports [1,2], where extensive literature searches were also reported. There are at least eight different stored chemical energy propulsion (SCEPS) reactions involving various fuel/oxidant pairs which are of interest. Several of these reactions involve more than one stage. Reactions or reaction groups considered are:

$$
\begin{aligned}
& \left.\begin{array}{l}
2 \mathrm{Li}(l)+\mathrm{H}_{2} \mathrm{O}(g) \rightarrow 2 \mathrm{LiOH}(l)+\mathrm{H}_{2}(g) \\
g)+(1 / 2)_{2} \mathrm{O}_{2}(g) \rightarrow \mathrm{H}_{2} \mathrm{O}(g)
\end{array}\right\} \\
& 2 \mathrm{Li}(l)+\mathrm{H}_{2} \mathrm{O}(\mathrm{g}) \rightarrow 2 \mathrm{LiOH}(l)+\mathrm{H}_{2}(\mathrm{~g}) \\
& (2 / 3) \mathrm{NaO}_{2}(c)+(1 / 3) \mathrm{H}_{2} \mathrm{O}(g) \rightarrow(2 / 3) \mathrm{NaOH}(c)+(1 / 2) \mathrm{O}_{2}(g) \\
& \mathrm{H}_{2}(\mathrm{~g})+(1 / 2) \mathrm{O}_{2}(\mathrm{~g}) \rightarrow \mathrm{H}_{2} \mathrm{O}(\mathrm{g}) \\
& \left.\begin{array}{l}
2 \mathrm{MgAl}(l)+5 \mathrm{H}_{2} \mathrm{O}(\mathrm{g}) \rightarrow \mathrm{MgO}(\mathrm{c})+\mathrm{MgAl}_{2} \mathrm{O}_{4}(\mathrm{c})+5 \mathrm{H}_{2}(g) \\
5 \mathrm{H}_{2}(g)+(5 / 2) \mathrm{O}_{2}(g) \rightarrow 5 \mathrm{H}_{2} \mathrm{O}(g)
\end{array}\right\} \\
& 2 \mathrm{LiAl}(l)+\mathrm{ClO}_{3} \mathrm{~F}(\mathrm{~g}) \rightarrow \mathrm{Al}_{2} \mathrm{O}_{3}(\mathrm{c})+\operatorname{LiF}(\mathrm{c})+\operatorname{LiCl}(l)
\end{aligned}
$$


$4 \operatorname{LiALMg}(l)+3 \mathrm{ClO}_{3} F(g) \rightarrow \mathrm{MgF}_{2}(c)+\operatorname{LiF}(c)+3 \operatorname{LiCl}(l)$

$$
+2 \mathrm{MgAl}_{2} \mathrm{O}_{4}(\mathrm{c})+\mathrm{MgO}(\mathrm{c})
$$

$8 \mathrm{Li}(l)+8 \mathrm{Be}(\mathrm{c})+\mathrm{ClO}_{3} \mathrm{~F}(\mathrm{~g}) \rightarrow 8 \mathrm{BeO}(\mathrm{c})+\mathrm{Li}_{2} \mathrm{O}(\mathrm{c})+3 \mathrm{LiF}(\mathrm{c})$

$$
\begin{gathered}
+\operatorname{LiCl}(l) \\
\mathrm{C}_{11} \mathrm{~F}_{20}(g)+20 \mathrm{Li}(l) \rightarrow 11 \mathrm{C}(\mathrm{c})+20 \mathrm{LiF}(\mathrm{c}) \\
2 \mathrm{Li}(l)+\mathrm{LiB}(\mathrm{c})+\mathrm{NF}_{3}(g) \rightarrow 3 \operatorname{LiF}(\mathrm{c})+\mathrm{BN}(\mathrm{c}) .
\end{gathered}
$$

Preliminary kinetic data on many of these reactions have been presented in an earlier report [2]; however results were limited to $650^{\circ} \mathrm{C}$ by reaction of the experimental container materials with oxidant (usually $\mathrm{ClO}_{3} \mathrm{~F}$ ) and/or with liquid metal. In this report experiments up to $800^{\circ} \mathrm{C}$ are described.

Reference [1] has dealt with phase equilibria in the system $\mathrm{Li}_{2} \mathrm{O}-\mathrm{Al}_{2} \mathrm{O}_{3}$. Phases on this join are products in several reaction schemes. In the present report, additional data are presented for the high alumina end of the system. We also discuss equilibration experiments on the thermodynamically predicted reaction products in several of the reactions (1) through (8). These experiments have led to the postulation of extensive fluorine substitution in at least one oxide phase. Finally, experimental results indicate the widespread importance of the gas phase as a transport medium, and we report mass spectrometric measurements on the gas phase, including the use of a high pressure mass spectrometry system developed in this laboratory. Supplementing these measurements are thermodynamic calculations of vapor pressures over products and 
reactants at high temperatures for the various reaction schemes. Plans for follow-up research are given in the concluding section.

\section{REACTION VERIFICATION}

\section{A. Equilibrium Among Predicted Product Phases}

Thermodynamically predicted products of various reactions from ref. [2] are given in Table 1. Results of experiments on reactions (1), (2), and (3) were given in ref. [2]; reaction (6) will not be investigated experimentally due to the toxicity of beryllium. Because of the kinetic and materials limitations indicated in this and previous reports, it has not yet been possible to obtain direct data on reactions $(4),(5),(7)$, and (8) to test the thermodynamic predictions. An indirect, though inconclusive test involves heating mixtures of the predicted products; if they do not react, this is consistent with the equilibrium predictions; however this circumstance is not proof, as kinetic factors could impede the attainment of equilibrium. Predicted products of reactions (4), (7), and ( 8 ) have been mixed together in equal parts by weight and equilibrated. Experimental results are shown in Table 2. These experiments were completed in a box furnace in sealed Pt capsules. Specimens were removed from the furnace and cooled in air (unless otherwise noted), then opened and $x$-rayed. Results for reactions (4) indicate formation of a spinel phase resembling $\mathrm{LiAl}_{5} \mathrm{O}_{8}$, at $1000^{\circ} \mathrm{C}$ and $1200^{\circ} \mathrm{C}$; reaction (4) is therefore not correct as written. As the alumina has vanished, and no other new phases are present, entry of fluorine into the spinel phase is a possibility, perhaps as a solid

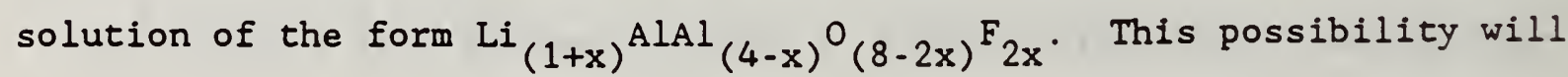


be discussed further in Section IV-B. The implication of the formation of oxyfluoride phases on the predicted energy yield of reaction (4) cannot be assessed without additional thermodynamic data. Reactions (7) and (8), however, may be correct as written, as the predicted products: $L i F+C$, and $L i F+B N$, respectively, show no sign of reaction when heated.

\section{B. $\quad \underline{\text { IiAlMg}} / \mathrm{ClO}_{3} \underline{\mathrm{F}}$ [reaction (5)]}

In reference [2] we described experiments on the $\mathrm{LiAl} / \mathrm{ClO}_{3} \mathrm{~F}$ reaction pair, which were limited by the inability to exceed temperatures above $650^{\circ} \mathrm{C}$, due to reaction of the molten fuel with the alumina; since that time we have investigated the use of $\mathrm{MgO}$ as a container, and it appears to function much better. The initial experiments done with this system utilized an MgO cup, into which was placed a small (25 mg) coupon of LiAlMg ternary alloy. The coupon was sliced from an ingot of alloy prepared by induction melting of the elemental constituents under an argon atmosphere in a tantalum crucible, followed by casting in a copper chill mold. The sample was placed in a Mettler ${ }^{1}$ TA-1 thermal analysis system on a magnesia substrate. First the sample was brought to a temperature of $800^{\circ} \mathrm{C}$ under argon. As the temperature was increased, relatively little weight change was noted, indicating that the activity of the $\mathrm{Mg}$ component in the alloy was sufficiently lowered to prevent the rapid volatization that would be experienced for pure $\mathrm{Mg}$ at this

${ }^{1}$ Certain commercial equipment, instruments, or materials are identified in this paper in order to adequately specify the experimental procedure. Such identification does not imply recommendation or endorsement by the National Bureau of Standards. 
temperature (refer to $\mathrm{Fig} .36$ ). After temperature was reached, $\mathrm{ClO}_{3} \mathrm{~F}$ gas was introduced at a constant flow rate of $2.5 \mathrm{cc} / \mathrm{min}$. A rapid and relatively constant rate of weight gain was observed, which abruptly halted after approximately $1 / 2$ hour. Upon examination of the charge, an intergrown felt-like mass of acicular crystals rimming the cell was observed. All that remained of the alloy coupon was a small metallic button. X-ray diffraction analysis of the felted mass of crystals indicated primarily $\mathrm{MgF}_{2}$ with lesser LiF. No x-ray evidence of aluminumcontaining phases was found in the crystalline mass. The metallic button is assumed to have been highly enriched in aluminum (an analysis was not possible). During this experiment a platinum gas feeder tube was used, as this had worked well at $650^{\circ} \mathrm{C}$. However at the $800^{\circ} \mathrm{C}$ temperature of this experiment, platinum transport was observed and so subsequent experiments used an alumina feeder tube for the $\mathrm{ClO}_{3} \mathrm{~F}$ (Section III-A).

The apparent transport of lithium and magnesium away from the reaction site in the presence of $\mathrm{ClO}_{3} \mathrm{~F}$ or its dissociation products is not predicted on thermodynamic grounds as the vapor pressures of the thermodynamically most stable salts such as $L i F$ and $A l F_{3}$ are relatively low at $800^{\circ} \mathrm{C}$ (see section IV-D). A possible explanation is that kinetic factors impede the development of a surface layer of the predicted equilibrium fluorides of $\mathrm{Mg}$ and $\mathrm{Li}$. Several possible reactions for transport of $\mathrm{Li}$ and $\mathrm{Mg}$ based on known vapor species exist. Some of these possibilities are indicated in Table 3 (alternative explanations, to be examined in future work, involve possible formation of new vapor complexes). Metal vaporization does not appear to be the principal 
mechanism, as there was not substantial weight loss from the ingot prior to the time the $\mathrm{ClO}_{3} \mathrm{~F}$ flow was initiated. Metastable formation of chloride species (including dimers, though these are not shown), is a mechanism that could lead to enhanced transport from the reaction site, as the chlorides of lithium and magnesium both have substantially higher vapor pressures than the fluorides (section IV-D). The fact that aluminum apparently did not migrate in this experiment may indicate the relative ease of formation of $\mathrm{AlF}_{3}$. Experiments described in a later section (III-C) point up the effectiveness of a very thin layer of crystalline $\mathrm{AlF}_{3}$ in preventing further reaction. Furthermore, $\mathrm{AlF}_{3}$ is solid at the temperature of the experiment, whereas the fluorides of $\mathrm{Mg}$ and Ii are molten, and would presumably facilitate diffusion of metal species to the reaction' site.

\section{Thermal Decomposition of $\mathrm{ClO}_{3} \mathrm{~F}$}

\section{Coupling of the Thermoanalyzer with a Mass Spectrometer} Failure of the Pt transport tube initially used to pipe $\mathrm{ClO}_{3} \mathrm{~F}$ into the hot reaction zone on the thermal analysis system occurred soon after the first experiments were conducted at $800^{\circ} \mathrm{C}$. Extensive thinning of the tube due to Pt removal from the inside and apparent redeposition near the exit point of the $\mathrm{ClO}_{3} \mathrm{~F}$ gas was observed. Formation of a platinum halide species was therefore suggested, which in turn implies decomposition of the $\mathrm{ClO}_{3} \mathrm{~F}$ gas. The platinum feeder tube was replaced by alumina, which has performed much better. Observations suggest that a thin relatively stable layer of microcrystalline solid $\mathrm{AlF}_{3}$ is formed on the surface of the alumina, which prevents further reaction of the alumina. Crucibles 
of alumina for the experiments with $\mathrm{ClO}_{3} \mathrm{~F}$ could thus be "presaturated" to constant weight together with their MgO inserts (if used) at the temperature of the experiment in flowing $\mathrm{ClO}_{3} \mathrm{~F}$ (this is discussed more fully in Sections III-A, B). Alloy starting materials were then added and the alloy reaction with $\mathrm{ClO}_{3} \mathrm{~F}$ studied as outlined above in Section II-A. Formation of fluoride reaction products in these experiments with apparent lack of any oxide phases suggested that only selected species within the gas phase were reacting, again raising the possibility of thermal decomposition of the $\mathrm{ClO}_{3} \mathrm{~F}$. According to the literature (refs. $[3,4]) \mathrm{ClO}_{3} \mathrm{~F}$ does not decompose up to the softening point of glass (e.g. $820^{\circ} \mathrm{C}$ for type 7740 Pyrex), even though it is thermodynamically unstable above $25^{\circ} \mathrm{C}$, according to data from JANAF [5].

In order to gather evidence for gaseous decomposition products, a leak valve was installed in the exhaust line of the thermal analysis system and a small portion of the exhaust gas was bled into the source of a modulated beam mass spectrometer system. Separate experiments with $\mathrm{ClO}_{3} \mathrm{~F}$ at room temperature indicate that electron bombardment at $30 \mathrm{eV}$ forms the parent and fragment ions, in order of decreasing intensity, $\mathrm{ClO}_{3}^{+}, \mathrm{ClO}_{2}^{+}$, $\mathrm{ClO}^{+}, \mathrm{ClO}_{3} \mathrm{~F}^{+}$, and $\mathrm{Cl}^{+}$. These ions, with the exception of the parent $\mathrm{ClO}_{3} \mathrm{~F}^{+}$, are a typical fragmentation pattern expected from electron impact with $\mathrm{ClO}_{3} \mathrm{~F}$ parent molecules.

Fig. 1 shows ion intensities as a function of temperature scaled using the ${ }^{40} \mathrm{Ar}^{+}$intensity as a reference (normalized to 100 ). These observations were made after the prefluorination reaction had taken place 
as indicated by the constancy in mass of the alumina cell. There is a large change in $\mathrm{O}_{2}^{+}$intensity between 500 and $700^{\circ} \mathrm{C}$. Also to be noted are the signals due to $\mathrm{Cl}_{2}^{+}$and $\mathrm{ClF}^{+}$at $700^{\circ} \mathrm{C}$. Near $500^{\circ}$ the $\mathrm{Cl}_{2}{ }^{+}$and ClF+ signals are very weak, and signals due to the normal fragmentation pattern of $\mathrm{ClO}_{3} \mathrm{~F}$ dominate the spectrum. Our interpretation of these data is that thermal decomposition of $\mathrm{ClO}_{3} \mathrm{~F}$ takes place between 500 and $700^{\circ} \mathrm{C}$. The formation of $\mathrm{Cl}_{2}{ }^{+}$and $\mathrm{ClF}^{+}$probably is due to recombination of $\mathrm{Cl}$ and $F$ formed in the decomposition reaction, as they are not normally formed by fragmentation of $\mathrm{ClO}_{3} \mathrm{~F}$. Also, the unusual behavior of the higher temperature part of the $\mathrm{ClO}^{+}$curve would be consistent with it being formed from recombination of decomposition products.

\section{ii. Analysis of $\mathrm{ClO}_{3} \mathrm{~F}$ Decomposition Using High Pressure} Sampling Transpiration Mass Spectrometry

We have developed in our laboratories a high pressure sampling mass spectrometric instrument for studying gas/solid interactions [6]. This instrument couples the classical transpiration method with a molecular beam mass spectrometric analysis of the reaction vapor species. In this technique, also known as transpiration mass spectrometry (TMS), gases formed in the reaction zone are expanded through a nozzle into a high vacuum system, where gases in the beam are mass analyzed [Fig. 2]. The expansion through the nozzle leads to the formation of a beam with a frozen vapor species composition representing the equilibrium or steadystate concentrations present the reaction cell. 
A significant advantage of use of the TMS system over the classical Knudsen effusion method is that it allows measurements to be made at pressures, approaching one atmosphere. This pressure region is much closer to that present in operating propulsion systems. Because of beam dynamics and the relatively high background pressures in the mass spectrometer section of the system, reactor pressures generally need to be in the range $10^{-4}$ atm and above before they can be observed. The system is usually operated as a fixed flow system and the flow rate as well as the total pressure are monitored during the experiment. The measured total pressure and mass spectral ion intensity of the carrier gas can be used to calibrate the system sensitivity and to determine the partial pressures of other species formed in the reaction cell, as described in ref. [6].

The thermal decomposition of $\mathrm{ClO}_{3} \mathrm{~F}$, as noted in section (1), leads to problems in data interpretation because of the possible recombination processes that may take place between the thermal analysis system and the mass spectrometer detector. The relatively long transit time between decomposition and detection is effectively eliminated by using the sampling system.

The decomposition of $\mathrm{ClO}_{3} \mathrm{~F}$ was observed in the TMS system by introducing $\mathrm{ClO}_{3} \mathrm{~F}$ into a fused silica transpiration reactor using argon as the carrier gas. The data obtained from these measurements is shown in Fig. 3 where the lines shown represent what we would expect for an experiment in which the scatter in the data is averaged out. The actual 
data have considerable scatter owing to technical problems resulting from decreases required in the flow rates initially selected in order to maintain the pressure in the optimum range. The change in flow rates results in relatively long time lags before the gas composition has had an opportunity to shift to new composition values because of the relatively small flow rate and large volume of the system.

The appearance of $\mathrm{Cl}_{2}$ and $\mathrm{O}_{2}$ as indicated by the ions $\mathrm{Cl}_{2}^{+}$and $\mathrm{O}_{2}{ }^{+}$, together with the concomitant disappearance of $\mathrm{ClO}_{3} \mathrm{~F}^{+}$and its fragment ions, indicates the decomposition of $\mathrm{ClO}_{3} \mathrm{~F}$ in the temperature range of $400-600^{\circ} \mathrm{C}$. Comparison of the ${ }^{37} \mathrm{ClO}_{3}{ }^{+}$and ${ }^{35} \mathrm{ClO}_{3}{ }^{+}$isotopic ion intensities indicates formation of an additional species of the same mass of $85 \mu$ (mass units) as ${ }^{37} \mathrm{ClO}_{3}^{+}$at temperatures above about $400^{\circ} \mathrm{C}$. The most reasonable assignment for this species is ${ }^{28} \mathrm{SiF}_{3}{ }^{+}$which arises from $\mathrm{SiF}_{4}$ produced by reaction of $F_{2}$ with the silica reaction cell. This species accounts for the apparent absence of $\mathrm{F}_{2}$ as a $\mathrm{ClO}_{3} \mathrm{~F}$ decomposition product, whereas $\mathrm{Cl}_{2}$ and $\mathrm{O}_{2}$ are observed. It can be noted that several ions ( $\mathrm{ClF}^{+}$and $\mathrm{ClO}^{+}$) observed in the thermoanalyzer mass spectrometer experiment were not observed in the TMS messurements which indicates that these species were probably formed by reaction of decomposition products during the relatively long transit time from the thermoanalyzer to the mass spectrometer system.

Complementary TMS data were obtained in the absence of a carrier gas. As noted above, the total pressures observed at constant flow rate are generally monitored during the measurements. These data also indicate 
thermal decomposition of $\mathrm{ClO}_{3} \mathrm{~F}$ in a similar temperature region to that noted in the Ar carrier gas experiments, as shown in Fig. 4. For a nondecomposing gas, a plot of pressure versus temperature will give a straight line whose slope is related to the number of moles per unit time flowing through the system. Note that in Fig. 4 there is a break in the curve near $530^{\circ} \mathrm{C}$, with pressures below and above this temperature being represented reasonably well by straight lines. The ratio of the slopes is 2.8 which is reasonably close to the ratio of the number of moles of gas of the products to reactants for the reaction,

$4 \mathrm{ClO}_{3} \mathrm{~F}(\mathrm{~g})+\mathrm{SiO}_{2}$ (fused quartz) $=2 \mathrm{Cl}_{2}(\mathrm{~g})+7 \mathrm{O}_{2}(\mathrm{~g})+\mathrm{SiF}_{4}(\mathrm{~g})$.

At the same time the pressure-temperature data was obtained the ion current from ${ }^{35} \mathrm{ClO}_{3}{ }^{+}$was observed. These data are plotted in Fig. 5 . The scatter in the low temperature region of the curve is a presently unexplained phenomenon which is apparently a result of changing the temperature.

III. KINETICS

\section{A. Reaction of $\mathrm{Al}_{2} \underline{\mathrm{O}}_{3}$ with $\mathrm{ClO}_{3} \underline{\mathrm{F}}$}

Upon failure of a Pt feeder tube used for the $\mathrm{ClO}_{3} \mathrm{~F}$, it was decided to test high purity alumina as a replacement, as this is commercially available in tubing of several sizes. To establish the long term behavior of $\mathrm{Al}_{2} \mathrm{O}_{3}$ in flowing $\mathrm{ClO}_{3} \mathrm{~F}$ at high temperature a series of thermogravimetric experiments was carried out. First it was noted that unused alumina crucibles could be heated to nearly constant weight in 
flowing $\mathrm{ClO}_{3} \mathrm{~F}$ (see Fig. 6). Windowless SEM/EDX analysis revealed the presence of a coating of faceted crystals giving a strong fluorine signal. This was interpreted as indicating development of an $\mathrm{AlF}_{3}$ coating. Presumably once formed this coating served as a diffusion barrier against further reaction. Assuming uniform formation of $\mathrm{AlF}_{3}$ on the inner surface of the alumina crucible of Fig. 7 an estimate of film thickness formed at $800^{\circ} \mathrm{C}$ would be about $10 \mu \mathrm{m}$.

To further explore the stability of $\mathrm{Al}_{2} \mathrm{O}_{3}$ in flowing $\mathrm{ClO}_{3} \mathrm{~F}$, experiments at temperatures from $450^{\circ}$ to $800^{\circ} \mathrm{C}$ were conducted using $0.3 \mu \mathrm{m}$ powders of Linde A alumina (998 corundum). Results are shown in Fig. 7 and Table 4. In these experiments, the samples were first brought to temperature and then the gas was introduced. X-ray powder diffraction analysis of the product indicated only $\mathrm{AlF}_{3}$. From Table 4, it can be seen that as the temperature reaches $700^{\circ} \mathrm{C}$ the weight gain approaches the theoretical value of 64.78 for complete conversion of the alumina powder according to the reaction:

$$
\mathrm{Al}_{2} \mathrm{O}_{3}(\mathrm{c})+3 \mathrm{~F}_{2}(\mathrm{~g}) \rightarrow 2 \mathrm{AlF}_{3}(\mathrm{c})+3 / 2 \mathrm{O}_{2}(\mathrm{~g})
$$

The effect of varying the rate of $\mathrm{ClO}_{3} \mathrm{~F}$ flow over the powdered alumina at $800^{\circ} \mathrm{C}$ is shown in Fig. 9. Although the rate of reaction, and hence the slope of the reaction curves vary, all show a well-defined reaction end point, which occurs at a weight gain of 93-948 of that for complete conversion to $\mathrm{AlF}_{3}$ (see Table 5). A substantial part of the reaction 
curves in Figs. 7-9 can be approximated by a parabolic rate law of the type:

$$
\left(\frac{\mathrm{W}}{\mathrm{A}}\right)^{2}=\mathrm{kt}
$$

where $W / A$ is the mass gained per unit area available for reaction, $k$ is the rate constant and $t$ is the cumulative reaction time. Calculated rate constants for the data in Figs. 8 and 9 are given in Table 6 , and the portions of the data which have been fitted in this way are indicated in the illustrations. Note that the early portions cannot be fitted in this fashion; the reason for this is not clear, but it may have to do with nucleation and growth of $\mathrm{AlF}_{3}$ product. The point at which the powdered alumina is consumed (reaction end point) is obvious on Figs. 8 and 9 . In the lower temperature $\left(450-600^{\circ} \mathrm{C}\right)$ experiments in Fig. 7, where a reaction end point is not observed, the rate constants show an Arrhenius relationship, as illustrated in Fig. 9. The equation of the line is

$$
\log k=7.63-7.06 \times 10^{3} / \mathrm{T}(\mathrm{K})
$$

Above $600^{\circ}$ this relationship is not followed, although the higher-flow rate experiments give $k^{\prime} s$ which lie closer to the Arrhenius line. This implies that above $660^{\circ} \mathrm{C}$, under the given experimental conditions, the supply of $\mathrm{ClO}_{3} \mathrm{~F}$ to the reaction interface may be the rate limiting factor for these high surface area experiments. It should be noted that the initial surface area used in plotting Figs. 7 and 8 , based on information provided by the manufacturer of Linde $A$, was $10-18 \mathrm{~m}^{2} / \mathrm{g}$; an average of $14 \mathrm{~m}^{2} / \mathrm{g}$ was used. In practice, this value may have been appreciably reduced as the sample heated up and as the reaction proceeded. This is also indicated by an attempt to calculate the thickness of the reaction 
layer on the powders, which gives a value a factor of 10 too low to be consistent with the nearly complete reaction of the $0.3 \mu \mathrm{m}$ powders, as observed above $600^{\circ} \mathrm{C}$.

\section{B. Reaction of $\mathrm{MgO}$ with $\mathrm{ClO}_{3} \mathrm{~F}$}

In a later section (IV-C) we describe the results of thermodynamic predictions for the interaction between $\mathrm{MgO}, \mathrm{Cl}_{2}$ and $\mathrm{F}_{2}$. The net result is that $\mathrm{MgF}_{2}$ should form at the expense of $\mathrm{MgO}$. Experiments were conducted on the thermoanalyzer to assess the importance of these reactions in the presence of $\mathrm{ClO}_{3} \mathrm{~F}$ (or its dissociation products) at $800^{\circ} \mathrm{C}$.

Results of an experiment using a coarsely crystalline Mgo cell are shown in Fig. 10, which indicates a "saturation" effect similar to that described above for $\mathrm{Al}_{2} \mathrm{O}_{3}$. Presumably this is due to formation of a thin layer of $\mathrm{MgF}_{2}$ which impedes further reaction, according to:

$$
\mathrm{MgO}(\mathrm{c})+\mathrm{F}_{2}(\mathrm{~g}) \rightarrow \mathrm{MgF}_{2}(\mathrm{c})+(1 / 2) \mathrm{O}_{2}(\mathrm{~g})
$$

Results obtained for crucibles fabricated of dense, polycrystalline sintered magnesia are similar. Experiments in which the flow rate of $\mathrm{ClO}_{3} \mathrm{~F}$ was varied during saturation of a polycrystalline cell show a nearly linear correlation between flow rate and rate of reaction. For the coarsely crystalline cell the calculated thickness of the $\mathrm{MgF}_{2}$ layer after 1 hour, is approximately $2 \mu \mathrm{m}$. As indicated, the final part of the data in Fig. 10 fit a parabolic rate law. 


\section{Reaction of $\mathrm{Mg}$ with $\mathrm{ClO}_{3}$ F}

A thermogravimetric experiment was attempted in which $\mathrm{Mg}$ metal was heated to $800^{\circ} \mathrm{C}$, preparatory to reaction with $\mathrm{ClO}_{3} \mathrm{~F}$. However the vapor pressure of $\mathrm{Mg}$ metal at temperatures above its melting point is such that significant evaporation occurs at the metal surface (see section IV-D), and for this reason it was not possible to complete the experiment at $800^{\circ} \mathrm{C}$. To minimize metal vaporization and obtain meaningful data; it may be necessary to complete future experiments at temperatures only slightly above the melting point of $\mathrm{Mg}\left(650^{\circ} \mathrm{C}\right)$.

\section{Reaction of Al with $\mathrm{ClO}_{3}$ E}

Once it was established that the $\mathrm{ClO}_{3} \mathrm{~F}$ decomposed at elevated temperatures, that the individual components of the Al-containing alloys react somewhat independently, and that $\mathrm{Al}$ does not react to the same degree as the other metal components, it was decided to focus more specifically on the problem of Al reaction by working with the pure metal. For quantitative reproducible kinetic studies, the following requirements are essential: minimization of experimental geometry effects; and constancy or quantification of relevant variables such as surface temperature, surface area, oxidant flow rate and ambient pressure. Surface area was made constant by selecting high purity aluminum-shot pieces of similar weight. It was found that these formed a nearly spherical ball (Fig. 11) in the $\mathrm{Al}_{2} \mathrm{O}_{3}$ crucible when melted, giving relatively constant surface area. During $\mathrm{ClO}_{3} \mathrm{~F}$ experiments at $800^{\circ} \mathrm{C}$, all Al droplets showed a "frosting" of the surface, which at higher magnification in the SEM proved to be a dense interlocking mass of well- 
faceted crystals (Fig. 12). SEM/windowless EDX showed Al and F, suggesting $\mathrm{AlF}_{3}$.

In the Al reaction experiments the proximity of the $\mathrm{ClO}_{3} \mathrm{~F}$ flow tube to the reaction surface was important. In the case where the exit port was -10 $\mathrm{mm}$ from the surface of the molten Al droplet, a tear-shaped channel, free of surface salts was formed, regardless of flow rate (Fig. 13). When the exit port was moved to $-15 \mathrm{~mm}$ from the surface, then no such salt-free channel was formed, although the surface of the ball had slight creases directly under the exit port. The reason for the salt-free scar at the close-in geometry is not clear. It is tempting to suggest a physical effect associated with the velocity of the inlet gas, however, this would be ordinarily thought to result in increased formation of salt so that any physical disturbance of the surface of the Al would be rapidly covered over by salt crystals (e.g., as seen in Fig. 12). The deep scar shown in Fig. 13, typical of experiments at the close-in geometry, is suggestive of removal of material from the surface of the Al. This would require both local formation of a volatile Al species and local suppression of the salt formation (presumably $A l F_{3}$ ) seen on the rest of the surface. A possible chain of events at the close-in geometry might be (assuming dissociation of the $\mathrm{ClO}_{3} \mathrm{~F}$ ):

$$
(3 / 2) \mathrm{Cl}_{2}(\mathrm{~g})+\mathrm{Al}(\mathrm{l}) \rightarrow \mathrm{AlCl}_{3}(\mathrm{~g})
$$

$$
\mathrm{AlCl}_{3}(\mathrm{~g})+(3 / 2) \mathrm{F}_{2}(\mathrm{~g}) \rightarrow \mathrm{AlF}_{3}(\mathrm{c})+(3 / 2) \mathrm{Cl}_{2}(\mathrm{~g})
$$

with the solid being precipitated away from the high flow area on the droplet surface. Hopefully this possibility can be tested using transpiration mass spectrometry. 
Thermogravimetric rate data for reaction of liquid $\mathrm{Al}$ with $\mathrm{ClO}_{3} \mathrm{~F}$ at 700 , 750 and $800^{\circ} \mathrm{C}$ are shown in Fig. 14 and summarized in Table 7 . The flow rate was nominally $1 \mathrm{sccm}$. The shapes of the three curves in Fig. 15 are similar, but the amplitude (total wt. gain of the Al droplets) increases by a factor of about seven going from 700 to $850^{\circ} \mathrm{C}$. The highest total weight gain $\left(800^{\circ} \mathrm{C}\right.$ experiment) is nonetheless small (2.75 mg) by comparison with a typical droplet weight (415 mg).

The effect of flow rate on reaction of $\mathrm{ClO}_{3} \mathrm{~F}$ with $\mathrm{Al}$ at $800^{\circ} \mathrm{C}$ is shown in Fig. 15 and summarized in Table 8. At the highest flow rate the shoulder in the curve is considerably rounded and the slope leading up to it is steeper relative to the two lower flow rates.

The curves in Figs. 14 and 15 are somewhat more complex than the $\mathrm{Al}_{2} \mathrm{O}_{3} / \mathrm{ClO}_{3} \mathrm{~F}$ curves of Figs. 7 and 8 . Preliminary interpretation can be made in terms of three different processes, each dominant in a different area of the curve: (a) initial region: nucleation and growth of $\mathrm{AlF}_{3}$ reaction sites; (b) middle region (nearly linear, to parabolic as shoulder is approached) lateral growth of $\mathrm{AlF}_{3}$ is lands at their edges, followed by merging of islands and complete coverage of the surface; (c) final region (parabolic): thickening of dense $A_{1} F_{3}$ film by diffusion through the film. A summary of the mathematical analysis of the data is given in Table 9. 


\section{E. Transpiration Mass Spectrometry (TMS) of the $\mathrm{Al} / \mathrm{C} 10_{3}$ F Reaction}

In measurements described in ref. [2], in which we examined the behavior of pure $\mathrm{Al}$ metal with $\mathrm{ClO}_{3} \mathrm{~F}$ using a gas entry Knudsen effusion method, the masses identified were $\mathrm{AlF}^{+}, \mathrm{AlCl}^{+}, \mathrm{AlF}_{2}^{+}, \mathrm{AlClF}^{+}, \mathrm{AlF}_{3}^{+}, \mathrm{AlF}_{2} \mathrm{Cl}^{+}$, $\mathrm{AlCl}_{2} \mathrm{~F}^{+}$, and $\mathrm{AlCl}_{3}{ }^{+}$. The period during which aluminum halide species were generated was quite short and the fraction of the sample which reacted was small. It was presumed that the sample became less reactive with time because of formation of either an $\mathrm{Al}_{2} \mathrm{O}_{3}$ or an $\mathrm{AlF}_{3}$ surface layer.

More recently, we have carried out TMS measurements on the $\mathrm{Al} / \mathrm{ClO}_{3} \mathrm{~F}$ reaction. These experiments were carried out in the absence of a carrier gas. A fragment of pure $\mathrm{Al}$ shot was placed in a $\mathrm{MgO}$ boat inside the fused silica transpiration cell. $\mathrm{ClO}_{3} \mathrm{~F}$ was introduced, and the product gases were analyzed mass spectrometrically. Ion intensities at $729^{\circ} \mathrm{C}$ are indicated in Table 10. Aluminum bearing vapor species were observed from 667 to $736^{\circ} \mathrm{C}$. All of the ions identified in the Knudsen experiment with the exception of $\mathrm{AlF}_{3}{ }^{+}$were detected; the vapor concentration of $\mathrm{AlF}_{3}(\mathrm{~g})$ in the above temperature range would be below the detection limits of the mass spectrometer. Also $\mathrm{O}_{2}^{+}, \mathrm{Cl}_{2}{ }^{+}$and $\mathrm{SiF}_{3}{ }^{+}$were observed during this feriod. The experiment was terminated because a significant decrease had taken place in all the ion signals as well as the total pressure. This behavior is not presently understood because the total pressure should have remained at least as high as that due to decomposition of $\mathrm{ClO}_{3} \mathrm{~F}$ unless erosion of the expansion nozzle took place or the unblocking of a partially blocked nozzle took place. 
It seems clear from the results of this experiment that the reaction of Al with $\mathrm{ClO}_{3} \mathrm{~F}$ takes place to a greater extent than was observed in the Knudsen effusion case at lower pressures. The remaining sample was removed from the magnesia cell at the conclusion of the experiment and observed to be covered with a white layer. An SEM examination of the surface deposit showed it to consist of columnar crystals aligned at right angles to the reaction surface. A windowless EDX spectrum showed the presence of oxygen, but no fluorine (fluorine was observed in the very top surface layer, however). Aluminum was the dominant constituent, with minor amounts of $\mathrm{Mg}$ (from the boat) and $\mathrm{Si}$ (from the silica cell). Apparently $\mathrm{Al}_{2} \mathrm{O}_{3}$ is the principal reaction product which implies that the fluorine activity has locally been reduced near the surface of the Al, thus suppressing the formation of the more stable $A l F_{3}$. A likely explanation is reaction of the fluorine component of the oxidant with the silica of the outer reaction cell; this is consistent with observation of silicon fluoride species in the mass spectrum of the exiting gases. Future experiments will utilize a different material for the outer cell. It is hoped that such experiments will also allow closer observation of any kinetic factors influencing the formation of aluminum chloride or fluoride species.

\section{PHASE EQUILIBRIA}

\section{A. Condensed Phase Equilibria of the System $\mathrm{LI}_{2} \underline{\mathrm{O}-\mathrm{Al}}_{2} \underline{\mathrm{O}}_{3}$}

\section{Melting and Solid Solution Relations}

Experiments, primarily on the $\mathrm{Li}_{2} \mathrm{O}-\mathrm{rich}$ end of the system $\mathrm{Li}_{2} \mathrm{O}-\mathrm{Al}_{2} \mathrm{O}_{3}$, were described in Ref. [1]. Many problems remain unresolved on the high 
alumina end of the system. Alumina-rich compositions are important for several reasons; they encompass reaction product phases, including $\mathrm{LiAlO}_{2}$ and $\mathrm{LiAl}_{5} \mathrm{O}_{8}$; the thermochemistry of these phases has implications for calculations of energy yield; as products of high stability, they have potential materials applications. The major challenge in working with these materials is the high temperature of the relevant equilibria, coupled with the non-quenchability of the samples. We have developed and refined a high temperature apparatus and methodology for dealing with these problems, as follows.

After homogenization, powdered mixtures were loaded into Mo capsules in a drybox, followed by sealing with a carbon arc welder. Samples (up to eight at a time) were then suspended in a Mo bucket in the hot zone of a tungsten furnace. Temperature was measured with a reinforced W3\&Re/W25\&Re thermocouple calibrated against the melting points of Pd and Pt and inserted into the Mo bucket in the center of the ring of samples. Generally calibrations were within 5 to $10^{\circ} \mathrm{C}$ of the correct melting points. Thermal gradients along the length and diameter of the holder were less than $5^{\circ} \mathrm{C}$ and so total uncertainty in the temperature is near $\pm 15^{\circ} \mathrm{C}$ to $\pm 20^{\circ} \mathrm{C}$, including control variation of $\pm 5^{\circ} \mathrm{C}$. Temperature was controlled via a second thermocouple in the base of the furnace. Experiments were terminated by allowing the furnace to cool (a typical cooling curve is shown in Fig. 16). Although cooling at this rate is not "quench", it is rapid enough to preserve many of the high temperature textural relationships. Following the experiments, the capsules were opened and products were examined by scanning electron microscopy. 
Generally it was possible to differentiate solids which were in equilibrium at the temperature of the experiment by their size (5 to $10 \mu \mathrm{m}$ ) and their well-developed facets. Crystals in equilibrium with melt tended to be somewhat larger than those formed in the absence of melt. Melts, if present, generally occupied the interstices between such crystals, and their microcrystalline descendants could be readily identified as in Fig. 17. Given the fact that the rate of cooling was not "quench", the crystallization history of such melts must be considered in making interpretations. For example the melt phase in Fig. 17 probably crystallized eutectically. Situtations where rims of material have crystallized in an oriented fashion around the larger grains may possibly indicate a peritectic, whereas in equigranular, porous specimens with sharp grain boundaries, melt was apparently never present. Using data of this sort the diagram in Fig. 18 was developed. The apparent lack of melting at temperatures below $1950^{\circ} \mathrm{C}$ for $\mathrm{Al}_{2} \mathrm{O}_{3}-\mathrm{rich}$ compositions could mean either presence of a compound intermediate between $\mathrm{LiAl}_{5} \mathrm{O}_{8}$ (most probably with incongruent melting), solid solution based on alumina, or possibly both. There is no $x$-ray evidence for solid solution or intermediate compounds; hence it is postulated that if such phases do exist they are unstable at lower temperatures, and decompose to a mixture of lithium spinel and corundum. Microstructural evidence for such decomposition is seen in the lamellar structure of Fig. 19.

\section{i1. Solid state Transition in $\mathrm{LiAl}_{5} \mathrm{O}_{8}$ spinel}

At lower temperatures the $\mathrm{LiAl}_{5} \mathrm{O}_{8}$ spinel phase undergoes a phase transition apparently related to ordering of $\mathrm{Li}$ and $\mathrm{Al}$ on the octahedral 
spinel sites. A Rietveld refinement of the structure of $\mathrm{LiAl}_{5} \mathrm{O}_{8}$ based on neutron diffraction data was given in reference [1]. This indicated essentially complete ordering of $\mathrm{Li}$ and $\mathrm{Al}$ in the octahedral sites, with no tetrahedral Li. Although this specimen had been equilibrated at about $1600^{\circ} \mathrm{C}$, apparently it was not cooled rapidly enough to freeze in the disordered state. Hence we still do not have good structural data on the high temperature disordered stage. During the past year, experiments were conducted on compositions from 50 to 100 moles $\mathrm{Al}_{2} \mathrm{O}_{3}$, to study in more detail the postulated order/disorder transition in $\mathrm{LiAl}_{5} \mathrm{O}_{8}$. The phase transition was observed to be reversible (Fig. 20). Upon cooling, the transition was relatively sluggish and required supercooling of about $25^{\circ} \mathrm{C}$ for initiation of the reaction at $1280^{\circ} \mathrm{C}$ which then apparently continues down to $1090^{\circ} \mathrm{C}$. Upon heating, a well-defined single thermal event was seen. The values of the heating event were used to define the temperature of the transition, as described in Ref. (1). Nine compositions were studied; temperatures of the transition were constant, but different on either side of the spinel composition (see Fig. 21). This implies that a slight degree of solid solution in the $1: 5$ composition exists, which nevertheless has a very pronounced effect (nearly $30^{\circ} \mathrm{C}$ ) on the transition. The effect of annealing at temperatures above and below the phase transition on the $\mathrm{x}$-ray powder pattern is manifested in the intensity ratios of several of the lines, which is consistent with an order/disorder transition. 
B. Condensed Phase Equilibria in the System $\mathrm{Li}_{2} \underline{\mathrm{O}}_{\mathrm{Al}}{ }_{2} \underline{\mathrm{O}}_{3}-\mathrm{AlF}_{3}=\mathrm{LiF}$

As noted above in Section II-B, experiments to verify the products of reaction (4) suggested the existence of a spinel phase containing fluorine. Several experiments have been conducted to follow up this possibility, which is of both crystal-chemical interest and also of importance to the rheological properties of predicted solid/liquid products. Assuming that there are no anion vacancies, fluorine substitution can be plotted in the ternary reciprocal system $\mathrm{Li}, \mathrm{Al} / / \mathrm{F}, 0$.

Experiments on the compositions plotted in Fig. 22 have been completed at $1200^{\circ} \mathrm{C}$ in the system. The purpose of these experiments has been to locate a single-phase region of fluorine-substituted spinel. Evidence for lack of the expected degree of melting at $1200^{\circ} \mathrm{C}$ in most compositions on the $\mathrm{Li}_{2} \mathrm{O}$-rich side of the $\mathrm{LiF}-\mathrm{Al}_{2} \mathrm{O}_{3}$ join in the ternary reciprocal system $\mathrm{Li}_{2} \mathrm{O}-\mathrm{Al}_{2} \mathrm{O}_{3}-\mathrm{AlF}_{3}-\mathrm{LiF}$ comes from: visual observation, SEM high magnification examination, and powder $x$-ray diffraction data. Since the minimum melting temperature along the join $\mathrm{LiF}-\mathrm{AlF}_{3}$ is $710^{\circ} \mathrm{C}$, it would be expected that fluoride phases would be present as melts at the experimental temperature. The $x$-ray data are somewhat ambiguous; nearly all experimental results give weak lines at positions corresponding to the major lines for $\mathrm{LiF}$ and $\mathrm{Li}_{3} \mathrm{AlF}_{6}$. Possible explanations include: (1) small amounts of unreacted salt; (2) small amounts of equilibrium melt; (3) superstructure lines which happen to fall at the LiF and $\mathrm{Li}_{3} \mathrm{AlF}_{6}$ positions. Possibility (2) is judged most likely. On the basis of intensities of $\mathrm{LiF}$ and $\mathrm{Li}_{3} \mathrm{AlF}_{6}$ lines, compositions near 
$75\left(2 \mathrm{LiF} . \mathrm{Al}_{2} \mathrm{O}_{3}\right): 25\left(\mathrm{LiAl}_{5} \mathrm{O}_{8}\right)$ are nearly single phase. Results of SEM examination of a series of $1200^{\circ} \mathrm{C}$ quench experiments along the join $\mathrm{LiAl}_{5} \mathrm{O}_{8}-\left(\mathrm{LiF} . \mathrm{Al}_{2} \mathrm{O}_{3}\right)$ indicate that with increasing LiF concentration, the fraction of well-faceted spinel crystals increases until at $75\left(2 \mathrm{LiF} . \mathrm{Al}_{2} \mathrm{O}_{3}\right): 25\left(\mathrm{LiAl}_{5} \mathrm{O}_{8}\right)$ the sample is comprised almost entirely of well-faceted spinel crystals (Fig. 23-a). On the other hand, at the 2LiF. $\mathrm{Al}_{2} \mathrm{O}_{3}$ composition, evidence for a melt is clear at high magnification (Fig. 23-b). The interpretation of the SEM and $x$-ray observations is summarized in the $1200^{\circ} \mathrm{C}$ isothermal phase diagram of Fig. 24 .

\section{Thermodynamics of Competing Oxidation Reactions}

Some experimental observations made during this work indicated that selective reactions were taking place. For example, $\mathrm{ClO}_{3} \mathrm{~F}$ reaction with a Li/Al alloy tended to form only halides with no indication of oxide formation. Also, during reaction for $\mathrm{ClO}_{3} \mathrm{~F}$ with a $\mathrm{Mg}$ alloy, $\mathrm{MgF}_{2}$ (c) was observed to have been transported to the side of the reaction crucible even though the vapor pressure of $\mathrm{MgF}_{2}$ was too low to account for the transport at $800^{\circ} \mathrm{C}$. A possible explanation is that transport was due to $\mathrm{MgCl}_{2}$ which condensed and underwent a halide exchange reaction with $\mathrm{F}_{2}$. This is evidence that, at least under laboratory conditions, the paths of the chemical reactions are being governed by both thermodynamic and kinetic factors.

To investigate these processes we considered the known thermodynamic data governing these reactions. For purposes of this discussion we will 
categorize reactions based on the standard Gibb's energies of formation of the halides and oxides into the following types:

(a) interaction of chlorides and fluorides with metals;

(b) interaction of oxides with fluorine or chlorine;

(c) reaction of chlorides with fluorine;

(d) interaction of chlorides with fluorides;

(e) interaction of oxides with fluorides;

(f) interaction of oxides with chlorides.

Data for these types of reactions are listed in Tables 11 through 16. The tables list the Gibb's energy of the reactions, as written, in calories for temperatures from 800 through $1300 \mathrm{~K}$ respectively. As usual, positive free energies indicate that the reactants are the predominant materials present at equilibrium and negative free energies indicate that the products are the predominant materials present. The state selected for the individual substances was based on vapor pressure, melting point and phase equilibrium considerations. Thus, it was assumed that $\mathrm{AlCl}_{3}$ and $\mathrm{BeCl}_{2}$ would be present as gases, that most of the halide reaction products would be liquids, and that oxides except for $\mathrm{Li}_{2} \mathrm{O}$ would be present as solids. Effects due to the possible formation of mixed halide species such as $\mathrm{AlClF}_{2}$ have been ignored in the present calculations.

Data in Table 11 correspond to the displacement of a metal from a less stable metal halide to form a more stable metal halide. From the reactions considered it is clear that if equilibrium was maintained 
during the reaction the metals would be consumed in the order:

$$
\mathrm{Li}>\mathrm{Mg}>\mathrm{Be}>\mathrm{Al} \text {. }
$$

Results in Table 12 show that none of the metal oxides are thermodynamically stable in the presence of $F_{2}(g)$ while only the relatively reactive $\mathrm{Li}_{2} \mathrm{O}(l)$ is unstable in the presence of $\mathrm{Cl}_{2}(\mathrm{~g})$.

Table 13 shows that none of the chlorides are stable in the presence of fluorine and will be converted to fluorides, while Table 14 expresses possible interaction reactions among chlorides and fluorides.

Tables 15 and 16 list possible equilibria for oxide-fluoride and oxidechloride reactions. These data show which oxide-halide couples are stable or unstable. For example, $\mathrm{Al}_{2} \mathrm{O}_{3}$ will not react with $\mathrm{BeF}_{2}$, LiF, or $\mathrm{MgF}_{2} ; \mathrm{BeO}$ is resistant to LiF; and $\mathrm{MgF}_{2}$ and $\mathrm{MgO}$ are resistant to LiF. On the other hand, $\mathrm{MgO}$ is not resistant to $\mathrm{AlF}_{3}$ or $\mathrm{BeF}_{2}, \mathrm{BeO}$ is not resistant to $\mathrm{AlF}_{3}$, and $\mathrm{Li}_{2} \mathrm{O}$ is not resistant to any of the fluorides.

The tabular data can also be represented graphically as in Figs. 25-30. In Fig. 25, for example we consider possible chemical equilibria of chlorides formed by reaction with a $338 \mathrm{Mg}$ - $338 \mathrm{Li}$ - $338 \mathrm{Al}$ alloy. For the calculation, activities of $\mathrm{Mg}$ and $\mathrm{Li}$ metal are set equal to the mole fractions and Al is treated as a diluent while it is assumed that the activity of $\mathrm{LiCl}$ is $0.1,0.5$, or 0.9 . We then calculate the ratio of the activities of $\mathrm{MgCl}_{2} / \mathrm{LiCl}$ as a function of temperature. The calculated 
activity ratio varies from $10^{-14}$ to $10^{-7}$ showing that given this set of conditions and assuming thermodynamic equilibrium, essentially no $\mathrm{MgCl}_{2}$ is formed until all of the $\mathrm{Li}$ has reacted to form LiCl. In Fig. 26 the same system is considered with regard to the chlorides of $\mathrm{Mg}$ and $\mathrm{Al}$ ( $\mathrm{Li}$ is treated as a diluent); as indicated, the result that the $\mathrm{MgCl}_{2} / \mathrm{AlCl}_{3}$ ratio varies between $10^{-23}$ and $10^{-15}$. Thus, the $\mathrm{Li} / \mathrm{Mg} / \mathrm{Al}$ alloy system would react with $\mathrm{Cl}_{2}$ to form first $\mathrm{LiCl}$ followed by $\mathrm{MgCl}_{2}$ and finally $\mathrm{AlCl}_{3}(\mathrm{~g})$. The results of similar calculations for fluoride reactions in this alloy system are shown in Fig. 27 and 28 . Fig. 27 shows that LiF is formed preferentially over $\mathrm{MgF}_{2}$ while Fig. 28 shows the preferential formation of LiF over $\mathrm{AlF}_{3}$. Again, as with the chlorides, the order of fluorine reaction in a system at thermodynamic equilibrium would first consume all $\mathrm{Li}$ followed by $\mathrm{Mg}$ and finally $\mathrm{Al}$. Figs. 29 and 30 demonstrate that $\mathrm{LiF}$ and $\mathrm{MgF}_{2}$ will be formed in preference to $\mathrm{LiCl}$ and $\mathrm{MgCl}_{2}$ even if $\mathrm{Cl}_{2}(\mathrm{~g})$ is present at much higher concentrations than $\mathrm{F}_{2}(\mathrm{~g})$.

To summarize, formation of oxides will be negligible in the presence of $F_{2}$ until all the fluorine has been used up. Next, oxides will form if thermodynamic equilibrium is achieved. Note that generally this is not what we have observed in laboratory studies but this probably means that the activation energy necessary to form the oxides is not achieved in the temperature region we are obtaining. Finally chlorides will be formed. However, note that the thermodynamic data predicts that only $\mathrm{Li}_{2} \mathrm{O}$ will react with $\mathrm{Cl}_{2}(g)$. Thus, these calculations suggest that there may be problems in obtaining relatively complete or uniform combustion. 


\section{Reactant/Product Vapor Pressures}

It is necessary to consider vapor pressures of reactants or expected products formed in the various combustion systems. In the case of a $\mathrm{Li} / \mathrm{Al}$ or $\mathrm{Li} / \mathrm{Mg}$ alloy with which water is reacted, the $\mathrm{Li}$ in the condensed phase could absorb $\mathrm{H}_{2}$ to form $\mathrm{LiH}$. Fig. 31 shows the $\mathrm{H}_{2}$ pressure over pure LiH(l) based on data from the JANAF tables [5]. These data assume that both $\mathrm{Li}$ and $\mathrm{LiH}(\ell)$ are pure phases. In reality $\mathrm{Li}$ dissolves to some extent in the $\operatorname{LiH}(\ell)$ so that the pressure is actually less than this estimate. Note that the $\mathrm{H}_{2}$ pressure is close to an atmosphere at $1200 \mathrm{~K}$. The effect of a second alloying element might decrease this pressure and the Ii activity might be decreased by as much as a factor of two. In spite of this, Li alloy at lower temperatures might absorb a significant fraction of the $\mathrm{H}_{2}$ produced thus reducing the amount of $\mathrm{H}_{2}$ available for reaction.

Fig. 32 shows that $\mathrm{LiOH}(\mathrm{g})$ could present a transport problem in reactions (1) and (2). Also it could be significant that the water pressure over LiOH at $1300 \mathrm{~K}$ approaches one atm, raising the possibility of producing $\mathrm{Li}_{2} \mathrm{O}$, and thereby increasing the energy yield. By contrast, Fig. 33 indicates that the pressures of LiCl and LiF are to low to be relevant to transport processes by vaporization.

Data shown in Fig. 34 for the Al halides indicates that very high pressures could be established by $\mathrm{AlCl}_{3}(g)$. JANAF[5] reports a critical temperature of $620 \mathrm{~K}$ and a critical pressure of $24.3 \mathrm{~atm}$. Our measurements show the formation of mixed halide vapors formed by the 
reaction of $\mathrm{ClO}_{3} \mathrm{~F}$ with Al metal. JANAF tabulates data for some of the mixed halide species. This problem will receive further consideration in subsequent studies.

Fig. 35 shows the $\mathrm{BeCl}_{2}, \mathrm{Be}_{2} \mathrm{Cl}_{4}$, and $\mathrm{BeF}_{2}$ vapor pressure curves. As with $\mathrm{AlCl}_{3}$, the vapor pressure of $\mathrm{BeCl}_{2}$ will be very high at $1200 \mathrm{~K}$.

Estimates based on the JANAF[5] tabulation indicate a pressure of 90 atm at $1200 \mathrm{~K}$.

In Fig. 36 vapor pressure data for $\mathrm{Mg}(\mathrm{g})$, and $\mathrm{MgCl}_{2}$ are represented. The pressure of $\mathrm{Mg}(\mathrm{g})$ is about 0.2 atm at $1200 \mathrm{~K}$.

\section{v. DISCUSSION AND FUTURE DIRECTIONS}

It is apparent that in dealing with the complex high temperature chemistry of the multicomponent kinetic processes occurring during the stored chemical energy release reactions discussed here, it is necessary to consider the reaction behavior of the component pairs individually (e.g., $\mathrm{Al} / \mathrm{F}_{2}, \mathrm{Al} / \mathrm{Cl}_{2}, \mathrm{Al} / \mathrm{O}_{2}, \mathrm{Mg} / \mathrm{F}_{2}, \mathrm{Mg} / \mathrm{Cl}_{2}$, etc.) In future studies, rate data will be collected as a function of temperature for these basic reactions.

Phase equilibria, especially melting, determine to a large degree the properties of reaction products. Phase equilibrium measurements will be initiated on the system $\mathrm{Li}-\mathrm{Mg}-\mathrm{Al}-\mathrm{O}-\mathrm{F}$ to explore further the possibility of oxy-fluoride phase formation. 
A few comments concerning importance of vapor pressures in these propulsion systems should be made. In most of these systems where individual chloride and fluoride species are present, additional complex species each containing chlorine, fluorine and one or more metals may be formed leading to higher pressures than have been calculated here. The phenomenon of volatility enhancement by vapor complexing has been discussed in detail elsewhere [7]. Also, the temperature in the flame region of the device will likely be much higher than $1200 \mathrm{~K}$ leading to much higher pressures in the flame region. Since the walls of the device are cooler, condensation and vapor entrapment of fuel is a possible problem area. Hence, additional experiments are planned using high pressure transpiration mass spectrometry to identify the various species formed and to measure their partial pressures as well as to.examine the role of kinetic factors in gas phase transport.

VI. REFERENCES

1. L. P. Cook, E. R. Plante, R. S. Roth, and J. W. Hastie, 1984, "Phase Equilibria of Stored Chemical Energy Reactants", National Bureau of Standards Report No. NBSIR 84-2940, 103 p. (1984).

2. I. P. Cook and E. R. Plante, 1985, "Survey of Alternate Stored Chemical Energy Reactions", National Bureau of Standards Report No. NBSIR 85-3282, 106 p. (1985).

3. M. C. Sneed, J. L. Maynard, and R. C. Brasted, "Inorganic Chemistry", D. Van Nostrand Company Inc., New York, N.Y., Vol. 3, p. 29 (1954).

4. A. Engelbrecht and H. Atzanger, Monatsh. 83, p. 1087 (1952).

5. JANAF Thermochemical Tables, 2nd Ed., NSRDS-NBS 37, Washington, D.C. (1971). 
6. D. W. Bonnell and J. W. Hastie, Transpiration Mass Spectrometry of High Temperature Vapors, p 357, in "Characterization of High

Temperature Vapors and Gases", J. W. Hastie, ed.; NBS SP 561/1 and 2, U.S. Govt. Printing Office, Washington, D.C. (1979).

7. J. W. Hastie, "High Temperature Vapors", Acad. Press, New York, p. 480 (1975). 
Table 1. Thermodynamically Predicted Product Phases for SCEPS Reactions

Reaction

Predicted Products

(initial stage or stages)

(1) $\mathrm{Li} / \mathrm{H}_{2} \mathrm{O}, \mathrm{H}_{2} / \mathrm{O}_{2}$

LiOH, $\mathrm{H}_{2}$

(2) $\mathrm{Li} / \mathrm{H}_{2} \mathrm{O}, \mathrm{NaO}_{2} / \mathrm{H}_{2} \mathrm{O}, \mathrm{H}_{2} / \mathrm{O}_{2}$

LiOH, $\mathrm{H}_{2}, \mathrm{NaOH}, \mathrm{O}_{2}$

(3) $\mathrm{MgAl} / \mathrm{H}_{2} \mathrm{O}, \mathrm{H}_{2} / \mathrm{O}_{2}$

$\mathrm{MgO}, \mathrm{MgAl}_{2} \mathrm{O}_{4}, \mathrm{H}_{2}$

(4) $\mathrm{LiAl} / \mathrm{ClO}_{3} \mathrm{~F}$

$\mathrm{Al}_{2} \mathrm{O}_{3}, \mathrm{LiF}, \mathrm{LiCl}$

(5) $\mathrm{LiAlMg} / \mathrm{ClO}_{3} \mathrm{~F}$

$\mathrm{MgF}_{2}, \mathrm{LiF}, \mathrm{LiCl}, \mathrm{MgAl}_{2} \mathrm{O}_{4}, \mathrm{MgO}$

(6) $\mathrm{LiBe} / \mathrm{ClO}_{3} \mathrm{~F}$

$\mathrm{BeO}, \mathrm{Li}_{2} \mathrm{O}, \mathrm{LiF}, \mathrm{LiCl}$

(7) $\mathrm{Li} / \mathrm{C}_{11} \mathrm{~F}_{20}$

C, LiF

(8) $\mathrm{LiB} / \mathrm{NF}_{3}$

LIF, BN 
Table 2. Experimental Test of Thermodynamically Predicted SCEPS Product Phases

\begin{tabular}{|c|c|c|c|c|}
\hline Reaction & $\begin{array}{l}\text { Starting } \\
\text { Materials }\end{array}$ & $\begin{array}{l}\text { Temp. } \\
\left({ }^{\circ} \mathrm{C}\right)\end{array}$ & $\begin{array}{l}\text { Time } \\
\text { (hr) }\end{array}$ & $\begin{array}{c}\text { X-ray Analysis } \\
\text { of Results }\end{array}$ \\
\hline (4) & $\mathrm{LiF}, \mathrm{LiCl}, \mathrm{Al}_{2} \mathrm{O}_{3}$ & 600 & 48 & $\begin{array}{l}\mathrm{LiCl}, \operatorname{LiCl} \mathrm{H}_{2} \mathrm{O}^{*} \\
\mathrm{Al}_{2} \mathrm{O}_{3} \text {, LiF }\end{array}$ \\
\hline (4) & $\mathrm{LiF}, \mathrm{LiCl}, \mathrm{Al}_{2} \mathrm{O}_{3}$ & 800 & 23 & $\begin{array}{l}\mathrm{LiCl}, \mathrm{LiCl} \mathrm{H}_{2} \mathrm{O}^{\star} \\
\mathrm{Al}_{2} \mathrm{O}_{3}, \mathrm{LiF}\end{array}$ \\
\hline (4) & $\mathrm{LiF}, \mathrm{LiCl}, \mathrm{Al}_{2} \mathrm{O}_{3}$ & 1000 & 23 & $\mathrm{LiCl}, \mathrm{LiF}, \mathrm{LiAl}_{5} \mathrm{O}_{8}$ \\
\hline$(4)$ & $\mathrm{LiF}, \mathrm{LiCl}, \mathrm{Al}_{2} \mathrm{O}_{3}$ & 1200 & $\begin{array}{c}116 \\
\text { (quenched) }\end{array}$ & $\begin{array}{l}\mathrm{LiCl}, \mathrm{LiCl} \mathrm{H}_{2} \mathrm{O}^{*} \\
\mathrm{LiF}, \mathrm{LiAl}_{5} \mathrm{O}_{8}\end{array}$ \\
\hline (7) & LiF,C & 1200 & 24 & LiF, C \\
\hline (8) & LiF, BN & 600 & 18 & LiF, BN \\
\hline$(8)$ & LIF, BN & 800 & 24 & LiF, $B N$ \\
\hline (8) & LiF, BN & 1000 & 22 & LiF, BN \\
\hline
\end{tabular}

*hydration upon atmospheric exposure 
Table 3. Possibilities for Enhanced Local Transport of Li, Mg

A. Metal vaporization

(1) $\mathrm{Ii}(\ell) \rightarrow \mathrm{Li}(g)$

(2) $2 \operatorname{Li}(g)+F_{2}(g) \rightarrow 2 \operatorname{LiF}(c)$

(3) $\mathrm{Mg}(\mathrm{L}) \rightarrow \mathrm{Mg}(g)$

(4) $\mathrm{Mg}(g)+F_{2}(g) \rightarrow \mathrm{MgF}_{2}(\mathrm{c})$

B. Metastable formation of chloride species

(1) $2 \mathrm{Li}(\mathrm{l})+\mathrm{Cl}_{2}(\mathrm{~g}) \rightarrow 2 \mathrm{LiCl}(\mathrm{g})$

(2) $2 \operatorname{LiCl}(g)+F_{2}(g) \rightarrow 2 \operatorname{LiF}(c)+\mathrm{Cl}_{2}(g)$

(3) $\mathrm{Mg}\left(\right.$ l) $+\mathrm{Cl}_{2}(g) \rightarrow \mathrm{MgCl}_{2}(g)$

(4) $\mathrm{MgCl}_{2}(g)+\mathrm{F}_{2}(g) \rightarrow \mathrm{MgF}_{2}(\mathrm{c})+\mathrm{Cl}_{2}(g)$

C. Combined mechanism

(1) $\mathrm{Ii}($ l) $\rightarrow \mathrm{Ii}(\mathrm{g})$

(2) $2 \mathrm{Ii}(g)+\mathrm{Cl}_{2}(g) \rightarrow \mathrm{IiCl}(g)$

(3) $2 \operatorname{LiCl}(g)+F_{2}(g) \rightarrow 2 \operatorname{LiF}(c)$

(4) $\mathrm{Mg}(2) \rightarrow \mathrm{Mg}(g)$

(5) $\mathrm{Mg}(\mathrm{g})+\mathrm{Cl}_{2}(\mathrm{~g}) \rightarrow \mathrm{MgCl}_{2}(\mathrm{~g})$

(6) $\mathrm{MgCl}_{2}(g)+\mathrm{F}_{2}(g) \rightarrow \mathrm{MgF}_{2}(\mathrm{c})$ 
Table 4. Weight Gain of $0.3 \mu \mathrm{m}$ Alumina as a Function of Temperature in Flowing $\mathrm{ClO}_{3} \mathrm{~F}$ (nominal flow rate of $1 \mathrm{sccm}$ )

\begin{tabular}{lcrcccc}
\hline $\begin{array}{l}\text { Temp. } \\
\left({ }^{\circ} \mathrm{C}\right)\end{array}$ & $\begin{array}{l}\text { Time } \\
(\mathrm{hr})\end{array}$ & $\begin{array}{c}\text { Initial } \\
\text { Wt. (mg) }\end{array}$ & $\begin{array}{c}\text { Wt. } \\
\text { Gain (mg) }\end{array}$ & $\begin{array}{c}\text { 8 Wt. } \\
\text { Gain }\end{array}$ & $\begin{array}{c}\text { End } \\
\text { Point }\end{array}$ & $\begin{array}{c}\text { \& of } \\
\text { Theoretical Max. }\end{array}$ \\
\hline 450 & 1.5 & 116.6 & 18.3 & 15.7 & $\mathrm{~N}$ & 24.3 \\
500 & 1.5 & 119.2 & 34.8 & 29.2 & $\mathrm{~N}$ & 45.1 \\
550 & 1.5 & 91.7 & 47.1 & 51.4 & $\mathrm{~N}$ & 79.4 \\
600 & 0.9 & 95.4 & 53.4 & 56.0 & $\mathrm{Y}$ & 86.5 \\
690 & 1.4 & 94.6 & 55.8 & 59.0 & $\mathrm{Y}$ & 91.2 \\
700 & 1.3 & 78.9 & 47.6 & 60.3 & $\mathrm{Y}$ & 93.2 \\
750 & 1.3 & 77.3 & 48.7 & 63.0 & $\mathrm{Y}$ & 97.3 \\
800 & 1.4 & 95.1 & 59.5 & 62.6 & $\mathrm{Y}$ & 96.7 \\
\hline
\end{tabular}


Table 5. Effect of $\mathrm{ClO}_{3} \mathrm{~F}$ Flow Rate on Reaction with $0.3 \mu \mathrm{m}$ Alumina at $800^{\circ} \mathrm{C}$

\begin{tabular}{cccccc}
\hline $\begin{array}{c}\text { Approx. } \\
\begin{array}{l}\text { Flow Rate } \\
(\mathrm{sccm})\end{array}\end{array}$ & $\begin{array}{c}\text { Time to } \\
\text { Reaction } \\
\text { End Point } \\
(\mathrm{hr})\end{array}$ & $\begin{array}{c}\text { Initial } \\
\text { Wt. } \\
(\mathrm{mg})\end{array}$ & $\begin{array}{c}\text { Wt. } \\
\text { Gain } \\
\text { (mg) }\end{array}$ & $\begin{array}{c}\text { Wt. } \\
\text { Gain }\end{array}$ & $\begin{array}{c}\text { \% of } \\
\text { Max. }\end{array}$ \\
\hline 1 & 1.1 & 64.2 & 39.0 & 60.75 & 93.87 \\
3 & 1.0 & 129.8 & 78.6 & 60.55 & 93.56 \\
5 & 0.4 & 81.3 & 49.6 & 61.01 & 94.27 \\
\hline
\end{tabular}


Table 6. Calculated Rate Constants for Parabolic Portion of $\mathrm{Al}_{2} \mathrm{O}_{3} / \mathrm{ClO}_{3} \mathrm{~F}$ Reaction Data

\begin{tabular}{lcc}
$\begin{array}{l}\text { Temp } \\
\left.{ }^{\circ} \mathrm{C}\right)\end{array}$ & $\begin{array}{l}\text { Flow Rate } \\
(\mathrm{sccm})\end{array}$ & $\begin{array}{l}\text { Parabolic Rate } \\
\text { Constant } \\
\left(\mathrm{mg} / \mathrm{m}^{2} . \mathrm{s}\right)\end{array}$ \\
\hline 450 & 1 & 0.008 \\
500 & 1 & 0.003 \\
550 & 1 & 0.113 \\
600 & 1 & 0.358 \\
650 & 1 & 0.517 \\
700 & 1 & 0.573 \\
750 & 1 & 0.607 \\
800 & 1 & 0.584 \\
800 & 0.7 & 0.660 \\
800 & 3 & 0.711 \\
800 & 5 & 2.390 \\
\hline
\end{tabular}


Table 7. Weight Gain of Liquid Al Droplets as a Function of Temperature in Flowing $\mathrm{ClO}_{3} \mathrm{~F}$ (nominal flow rate of $1 \mathrm{sccm}$ )

\begin{tabular}{lccccc}
\hline $\begin{array}{l}\text { Temp. } \\
\left({ }^{\circ} \mathrm{C}\right)\end{array}$ & $\begin{array}{c}\text { Time } \\
(\mathrm{hr})\end{array}$ & $\begin{array}{c}\text { Initial Wt. } \\
(\mathrm{mg})\end{array}$ & $\begin{array}{c}\text { Calc. Surface } \\
\text { Area } \\
\left(\mathrm{cm}^{2}\right)\end{array}$ & $\begin{array}{c}\text { Wt. Gain } \\
(\mathrm{mg})\end{array}$ & $\begin{array}{c}\text { Calc. } \\
\text { Thickness of } \\
\text { Reaction Layer }(\mu \mathrm{m})^{*}\end{array}$ \\
\hline 700 & 0.3 & 420.0 & 1.52 & 0.34 & 2 \\
750 & 0.3 & 413.6 & 1.51 & 0.76 & 3 \\
800 & 0.8 & 418.2 & 1.52 & 2.75 & 10 \\
\hline
\end{tabular}

*Assumes uniform coverage of $\mathrm{AlF}_{3}$. 
Table 8. Effect of $\mathrm{ClO}_{3} \mathrm{~F}$ Flow Rate on Reaction with Liquid Al Droplets at $800^{\circ} \mathrm{C}$

\begin{tabular}{lccccc}
\hline $\begin{array}{l}\text { Approx. } \\
\begin{array}{l}\text { Flow Rate } \\
(\mathrm{sccm})\end{array}\end{array}$ & $\begin{array}{c}\text { Time } \\
(\mathrm{hr})\end{array}$ & $\begin{array}{c}\text { Initial Wt. } \\
(\mathrm{mg})\end{array}$ & $\begin{array}{c}\text { Calc. Surface } \\
\text { Area } \\
\left(\mathrm{cm}^{2}\right)\end{array}$ & $\begin{array}{c}\text { Wt. Gain } \\
(\mathrm{mg})\end{array}$ & $\begin{array}{c}\text { Calc. } \\
\text { Thickness of } \\
\text { Reaction Layer }(\mu \mathrm{m})^{*}\end{array}$ \\
\hline 0.7 & 0.3 & 411.6 & 1.50 & 1.9 & 7 \\
2.0 & 0.3 & 412.1 & 1.50 & 1.7 & 6 \\
5.0 & 0.2 & 417.9 & 1.52 & 1.8 & 7 \\
\hline
\end{tabular}

*Assumes uniform coverage of $\mathrm{AlF}_{3}$. 
Table 9. Calculated Rate Constants for Parabolic Portion of $\mathrm{Al} / \mathrm{ClO}_{3} \mathrm{~F}$ Reaction Data

\section{Temp}

$\left({ }^{\circ} \mathrm{C}\right)$

700

750

800

800

800

800
Nominal $\mathrm{ClO}_{3} \mathrm{~F}$

Flow Rate (cc/min)
Parabolic Rate

Constant $\left(\mathrm{mg} / \mathrm{m}^{2} . \mathrm{s}\right)$
1

1

1

0.7

3

6
27

155

149

1340

1260

2210 
Table 10. Mass Spectral Ion Intensities in the System $\mathrm{ClO}_{3} \mathrm{~F}-\mathrm{Al}$ at $725^{\circ} \mathrm{C}$

\begin{tabular}{ccc}
\hline Mass $(\mu)$ & Species & $\begin{array}{c}\text { Intensity } \\
\text { (microvolts) }\end{array}$ \\
\hline 32 & $\mathrm{O}_{2}$ & 6200 \\
46 & $\mathrm{AlF}^{+}$ & -5 \\
62 & $\mathrm{AlCl}^{+}$ & 140 \\
70 & $\mathrm{AlF}_{2}{ }^{+}$ & 50 \\
81 & $\mathrm{Cl}_{2}^{+}$ & 6600 \\
85 & $\mathrm{AlCl}^{+}$ & 110 \\
100 & $\mathrm{SiF}_{3}{ }^{+}$ & 1500 \\
116 & $\mathrm{AlF}_{2} \mathrm{Cl}^{+}$ & 55 \\
132 & $\mathrm{AlCl}_{2} \mathrm{~F}^{+}$ & 78 \\
\hline
\end{tabular}


Table 11. Interactions of Chlorides and Fluorides

\section{A. Exchange Reactions}

$$
\begin{aligned}
& \text { (1) } 2 \mathrm{Al}(l)+3 \mathrm{BeCl}_{2}(g)=3 \mathrm{Be}(\mathrm{c})=2 \mathrm{AlCl}(g) \\
& \text { (2) } 2 \mathrm{Al}(l)+3 \mathrm{BeF}_{2}(l)=3 \mathrm{Be}(\mathrm{c})+2 \mathrm{AlF}_{3}(l) \\
& \text { (3) } \mathrm{Al}(l)+3 \mathrm{LiCl}(l)=\mathrm{Li}(l)+\mathrm{AlCl}_{3}(g) \\
& \text { (4) } \mathrm{Al}(l)+3 \mathrm{MgCl}_{2}(l)=3 \mathrm{Li}(l)+\mathrm{AlF}_{3}(l) \\
& \text { (5) } 2 \mathrm{Al}(l)+3 \mathrm{MgCl}_{2}(l)=3 \mathrm{Mg}(l)+2 \mathrm{AlCl}_{3}(g) \\
& \text { (6) } 2 \mathrm{Al}(l)+3 \mathrm{MgF}_{2}(l)=2 \mathrm{AlF}_{3}(l)+\mathrm{Mg}(l) \\
& \text { (7) } 2 \mathrm{Li}(l)+\mathrm{BeCl}_{2}(g)=\mathrm{Be}(\mathrm{c})+2 \mathrm{LiCl}(l) \\
& \text { (8) } 2 \mathrm{Li}(l)+\mathrm{BeF}_{2}(\mathrm{c})=\mathrm{Be}(c)+2 \mathrm{LiF}(l) \\
& \text { (9) } 2 \mathrm{Li}(l)+\mathrm{MgCl}_{2}(l)=\mathrm{Mg}(l)+2 \mathrm{LiCl}(l) \\
& \text { (10) } 2 \mathrm{Li}(l)+\mathrm{MgF}_{2}(l)=\mathrm{Mg}(l)+2 \mathrm{LiF}(l) \\
& \text { (11) } \mathrm{Mg}(l)+\mathrm{BeCl}_{2}(g)=\mathrm{Be}(c)+\mathrm{MgCl}_{2}(l) \\
& \text { (12) } \mathrm{Mg}(l)+\mathrm{BeF}_{2}(l)=\mathrm{Be}(c)+\mathrm{MgF}_{2}(l)
\end{aligned}
$$

\begin{tabular}{|c|c|c|c|c|c|c|}
\hline Reaction & $\underline{800}$ & $\underline{900}$ & $\underline{1000}$ & $\underline{1100}$ & $\underline{1200}$ & $\underline{1300}$ \\
\hline (1) & 8,101 & 12,428 & 16,774 & 21,104 & 25,449 & 29,759 \\
\hline (2) & 53,692 & 54,383 & 55,163 & 56,044 & 56,988 & 58,031 \\
\hline (3) & 113,793 & 111,162 & 108,703 & 106,351 & 104,137 & 102,007 \\
\hline (4) & 84,883 & 84,984 & 85,193 & 85,498 & 85,858 & 86,315 \\
\hline (5) & 101,498 & 96,053 & 96,817 & 96,760 & 80,862 & 76,102 \\
\hline (6) & 94,960 & 95,485 & 96,028 & 96,617 & 97,296 & 98,057 \\
\hline (7) & $-73,162$ & $-69,965$ & $-66,877$ & $-63,866$ & $-60,942$ & $-58,085$ \\
\hline (8) & $-40,705$ & $-40,046$ & $-39,556$ & $-39,185$ & $-38,909$ & $-38,691$ \\
\hline (9) & $-42,030$ & $.42,090$ & $-42,196$ & $-42,314$ & $-42,471$ & $-42,637$ \\
\hline (10) & $-24,935$ & $-24,828$ & $-24,786$ & $-24,793$ & $-24,807$ & $-24,858$ \\
\hline (11) & $-31,132$ & $-27,875$ & $-24,681$ & $-21,552$ & $-18,471$ & $-15,448$ \\
\hline (12) & $-13,756$ & $-13,701$ & $-13,622$ & $-13,524$ & $-13,436$ & $-13,342$ \\
\hline
\end{tabular}

B. Gibbs Free Energies of Reaction (Calories)

Temperature (K)

C. Summary of Stabilities at $1300 \mathrm{~K}$ ( $\mathrm{x}=$ stable)

\begin{tabular}{c|c|c|c|c|c|c|c|c|} 
& $\mathrm{AlCl}_{3}$ & $\mathrm{AlF}_{3}$ & $\mathrm{BeCl}_{2}$ & $\mathrm{BeF}_{2}$ & $\mathrm{MgCl}_{2}$ & $\mathrm{MgF}_{2}$ & $\mathrm{LiCl}$ & $\mathrm{IIF}$ \\
\hline $\mathrm{AI}$ & $\mathrm{X}$ & $\mathrm{X}$ & $\mathrm{X}$ & $\mathrm{X}$ & $\mathrm{X}$ & $\mathrm{X}$ & $\mathrm{X}$ & $\mathrm{X}$ \\
\hline $\mathrm{Be}$ & 0 & 0 & $\mathrm{X}$ & $\mathrm{X}$ & $\mathrm{X}$ & $\mathrm{X}$ & $\mathrm{X}$ & $\mathrm{X}$ \\
\hline $\mathrm{Mg}$ & 0 & 0 & 0 & 0 & $\mathrm{X}$ & $\mathrm{X}$ & $\mathrm{X}$ & $\mathrm{X}$ \\
\hline $\mathrm{Li}$ & 0 & 0 & 0 & 0 & 0 & 0 & $\mathrm{X}$ & $\mathrm{X}$ \\
\hline
\end{tabular}


Table 12. Interaction of Oxides with Fluorine or Chlorine

\section{A. Exchange Reactions}

(1) $2 \mathrm{Al}_{2} \mathrm{O}_{3}(\mathrm{c})+12 \mathrm{~F}_{2}(\mathrm{~g})=\mathrm{AlF}_{3}(\mathrm{c})+3 \mathrm{O}_{2}(\mathrm{~g})$

(2) $2 \mathrm{BeO}(\mathrm{c})+2 \mathrm{~F}_{2}(\mathrm{c})=\mathrm{BeF}_{2}(\mathrm{~g})+\mathrm{O}_{2}(\mathrm{~g})$

(3) $2 \mathrm{Li}_{2} \mathrm{O}(\mathrm{c})+2 \mathrm{~F}_{2}(\mathrm{~g})=4 \operatorname{LiF}(\mathrm{l})+\mathrm{O}_{2}(\mathrm{~g})$

(4) $2 \mathrm{MgO}(\mathrm{c})+2 \mathrm{~F}_{2}(g)=2 \mathrm{MgF}_{2}(l)+\mathrm{O}_{2}(g)$

(5) $2 \mathrm{Al}_{2} \mathrm{O}_{3}(\mathrm{c})+6 \mathrm{Cl}_{2}(\mathrm{~g})=4 \mathrm{AlCl}_{3}(\mathrm{~g})+3 \mathrm{O}_{2}(\mathrm{~g})$

(6) $2 \mathrm{BeO}(c)+2 \mathrm{Cl}_{2}(g)=2 \mathrm{BeCl}_{2}(g)+\mathrm{O}_{2}(g)$

(7) $2 \mathrm{Li}_{2} \mathrm{O}(\mathrm{c})+2 \mathrm{Cl}_{2}(\mathrm{~g})=4 \mathrm{LiCl}(\mathrm{l})+\mathrm{O}_{2}(\mathrm{~g})$

(8) $2 \mathrm{MgO}(c)+2 \mathrm{Cl}_{2}(g)=2 \mathrm{MgCl}_{2}(l)+\mathrm{O}_{2}(g)$

\section{B. Gibbs Free Energies of Reaction (Calories)}

Temperature (K)

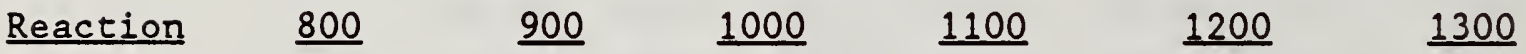

$\begin{array}{lllllll}\text { (1) } & -562,682 & -553,481 & -544,387 & -535,387 & -526,461 & -517,607\end{array}$

(2) $\quad \begin{array}{llllll}-132,802 & -138,020 & -143,180 & -148,287 & -153,345 & -158,379\end{array}$

$\begin{array}{lllllll}\text { (3) } & -272,435 & -271,964 & -271,635 & -271,428 & -271,285 & -271,230\end{array}$

$\begin{array}{lllllll}\text { (4) } & -212,096 & -210,745 & -209,444 & -208,202 & -207,077 & -206,048\end{array}$

(5) $\quad 160,087 \quad 150,226 \quad 140,453 \quad 130,782 \quad 121,224 \quad 111,744$

$\begin{array}{lllllll}\text { (6) } & 73,510 & 67,981 & 62,494 & 57,056 & 51,657 & 46,290\end{array}$

$\begin{array}{lllllll}\text { (7) } & -89,689 & -90,819 & -92,107 & -93,476 & -94,946 & -96,445\end{array}$

(8) $\quad 4,839 \quad 4,925 \quad 4,905 \quad 4,792 \quad 4,590 \quad 4,295$

C. Summary of Stabilities at $1300 \mathrm{~K}$ ( $\mathrm{x}=$ stable)

\begin{tabular}{l|c|c|} 
& $F$ & $C l$ \\
\cline { 2 - 3 } $\mathrm{Al}_{2} \mathrm{O}_{3}$ & 0 & $X$ \\
\hline $\mathrm{BeO}$ & 0 & $X$ \\
\hline $\mathrm{MgO}$ & 0 & $X$ \\
\hline $\mathrm{L} i_{2} \mathrm{O}$ & 0 & 0 \\
\hline
\end{tabular}


Table 13. Reaction of Chlorides with Fluorine

A. Exchange Reactions

(1) $2 \mathrm{AlCl}_{3}(\mathrm{~g})+3 \mathrm{~F}_{2}(\mathrm{~g})=2 \mathrm{AlF}_{3}(\mathrm{l})+\mathrm{Cl}_{2}(\mathrm{~g})$

(2) $\mathrm{BeCl}_{2}(g)+\mathrm{F}_{2}(g)=\mathrm{BeF}_{2}(l)+\mathrm{Cl}_{2}(g)$

(3) $2 \operatorname{LiCl}(l)+F_{2}(g)=2 \operatorname{LiF}(l)+\mathrm{Cl}_{2}(g)$

(4) $\mathrm{MgCl}_{2}(l)+\mathrm{F}_{2}(\mathrm{~g})=\mathrm{MgF}_{2}(l)+\mathrm{Cl}_{2}(\mathrm{~g})$

B. Gibbs Free Energies of Reaction (Calories)

Temperature (K)

$\underline{\text { Reaction }}$

$\underline{800}$

$\underline{900}$

$\underline{1000}$

1100

$\underline{1200}$

$\underline{1300}$

(1)

$-331,940$

$-324,073$

$-316,311$

$-308,633-301,067$

$-293,560$

(2)

$-125,844 \quad-122,009$

$-118,234$

$-114,525$

$-110,869$

$-107,277$

(3)

$-91,373 \quad-90,572$

$-89,764$

$-88,976 \quad-88,170$

$-87,392$

(4)

$-108,467$

$-107,835$

$-107,174$

$-106,497$

$-105,834$

C. Summary of Stabilities at $1300 \mathrm{~K}$ ( $0=$ unstable $)$

\begin{tabular}{c|c} 
& $F$ \\
\hline $\mathrm{AlCl}_{3}$ & 0 \\
\hline $\mathrm{BeCl}_{2}$ & 0 \\
\hline $\mathrm{LiCl}$ & 0 \\
\hline $\mathrm{MgCl}_{2}$ & 0 \\
\hline
\end{tabular}


Table 14. Interaction of Chlorides with Fluorides

\section{A. Exchange Reactions}

(1) $2 \mathrm{AlF}_{3}(l)+3 \mathrm{BeCl}_{2}(\mathrm{~g})=2 \mathrm{AlOl}_{3}(\mathrm{~g})+3 \mathrm{BeF}_{2}(l)$

(2) $\mathrm{AlF}_{3}(l)+3 \operatorname{LiCl}(\ell)=\mathrm{AlCl}_{3}(g)+3 \operatorname{LiF}(\ell)$

(3) $2 \mathrm{AlF}_{3}(l)+3 \mathrm{MgCl}_{2}(l)=2 \mathrm{AlCl}_{3}(g)+3 \mathrm{MgF}_{2}(l)$

(4) $\operatorname{BeF}_{2}(l)+2 \operatorname{LiCl}(l)=\mathrm{BeCl}_{2}(g)+2 \operatorname{LiF}(\ell)$

(5) $\mathrm{BeF}_{2}(l)+\mathrm{MgCl}_{2}(l)-\mathrm{BeCl}_{2}(g)+\mathrm{MgF}_{2}(l)$

(6) $2 \operatorname{LiF}(l)+\mathrm{MgCl}_{2}(l)=2 \operatorname{LiCl}(l)+\mathrm{MgF}_{2}(l)$

B. Gibbs Free Energies of Reaction (Calories)

Temperature (K)

Reaction

$\underline{800}$

$\underline{900}$

$\underline{1000}$

$\underline{1100}$

$\underline{1200}$

$\underline{1300}$

$\begin{array}{llllll}-45,591 & -41,955 & -38,509 & -34,940 & -31,539 & -28,272\end{array}$

(2)

$28,910 \quad 26,178 \quad 23,509 \quad 20,852 \quad 18,279 \quad 15,692$

(3)

$$
6,538
$$

0,568

$-5,212$

$2 \quad-10,857-16,434 \quad-21,955$

(4)

$\begin{array}{llllll}34,471 & 31,437 & 28,469 & 25,548 & 22,699 & 19,885\end{array}$

(5)

$17,376 \quad 14,174 \quad 11,059 \quad 8,028 \quad 5,035 \quad 2,106$

$\begin{array}{llllll}-17,094 & -17,263 & -17,410 & -17,520 & -17,664 & -17,779\end{array}$

C. Summary of Stabilities at $1300 \mathrm{~K}$ ( $\mathrm{x}=$ stable)

\begin{tabular}{c|c|c|c|c|} 
& $\mathrm{AlF}_{3}$ & $\mathrm{BeF}_{2}$ & $\mathrm{MgF}_{2}$ & $\mathrm{LiF}$ \\
\hline $\mathrm{AlCl}_{3}$ & $\mathrm{X}$ & $\mathrm{X}$ & $\mathrm{X}$ & 0 \\
\hline $\mathrm{BeCl}_{2}$ & $\mathrm{X}$ & $\mathrm{X}$ & 0 & 0 \\
\hline $\mathrm{MgCl}_{2}$ & 0 & $\mathrm{X}$ & $\mathrm{X}$ & 0 \\
\hline $\mathrm{LiCl}$ & $\mathrm{X}$ & $\mathrm{X}$ & $\mathrm{X}$ & $\mathrm{X}$ \\
\hline
\end{tabular}


Table 15. Interaction of Oxides with Fluorides

\section{A. Exchange Reaction}

(1) $\mathrm{Al}_{2} \mathrm{O}_{3}(c)+3 \mathrm{BeF}_{2}(l)=2 \mathrm{AlF}_{3}(l)+3 \mathrm{BeO}(\mathrm{c})$

(2) $\mathrm{Al}_{2} \mathrm{O}_{3}(c)+6 \operatorname{LiF}(l)=2 \mathrm{AlF}_{3}(l)+3 \mathrm{Li}_{2} \mathrm{O}(\mathrm{c})$

(3) $\mathrm{Al}_{2} \mathrm{O}_{3}(\mathrm{c})+3 \mathrm{MgF}_{2}(l)=2 \mathrm{AlF}_{3}(l)+3 \mathrm{MgO}(\mathrm{c})$

(4) $\mathrm{BeO}(c)+2 \operatorname{LiF}(l)=\mathrm{BeF}_{2}(l)+\mathrm{Ii}_{2} \mathrm{O}(\mathrm{c})$

(5) $\mathrm{BeO}(c)+\mathrm{MgF}_{2}(l)=\mathrm{BeF}_{2}(l)+\mathrm{MgO}(c)$

(6) $\mathrm{Ii}_{2} \mathrm{O}(\mathrm{c})+\mathrm{MgF}_{2}(l)=2 \mathrm{LiF}(\mathrm{l})+\mathrm{MgO}(\mathrm{c})$

B. Gibbs Free Energies of Reaction (Calories)

Temperature (K)

Reaction

$\underline{800} \quad \underline{900} \quad \underline{1000} \quad \underline{1100} \quad \underline{1200} \quad \underline{1300}$

(1)

$\begin{array}{llllll}15,370 & 15,097 & 14,875 & 14,747 & 14,666 & 14,710\end{array}$

(2)

$156,756 \quad 158,985 \quad 161,368 \quad 163,900 \quad 166,473 \quad 169,157^{\circ}$

(3)

$66,247 \quad 67,157 \quad 68,080 \quad 69,060 \quad 70,160 \quad 71,385$

(4)

$47,129 \quad 47,963 \quad 48,831 \quad 49,718 \quad 50,602 \quad 51,482$

(5)

$\begin{array}{llllll}16,959 & 17,353 \quad 17,735 & 18,104 & 18,498 & 18,892\end{array}$

(6)

$\begin{array}{llllll}-30,170 & -30,609 & -31,096 & -31,613 & -32,104 & -32,591\end{array}$

C. Summary of Stabilities at $1300 \mathrm{~K}$ ( $\mathrm{x}=$ stable)

\begin{tabular}{c|c|c|c|c|} 
& $\mathrm{AlF}_{3}$ & $\mathrm{BeF}_{2}$ & $\mathrm{MgF}_{2}$ & $\mathrm{LiF}$ \\
\hline $\mathrm{Al}_{2} \mathrm{O}_{3}$ & $\mathrm{X}$ & $\mathrm{X}$ & $\mathrm{X}$ & $\mathrm{X}$ \\
\hline $\mathrm{BeO}$ & 0 & $\mathrm{X}$ & $\mathrm{X}$ & $\mathrm{X}$ \\
\hline $\mathrm{MgO}$ & 0 & 0 & $\mathrm{X}$ & $\mathrm{X}$ \\
\hline $\mathrm{Li}_{2} \mathrm{O}$ & 0 & 0 & 0 & $\mathrm{X}$ \\
\hline
\end{tabular}


Table 16. Interaction of Oxides with Chlorides

\section{A. Exchange Reactions}

(1) $\mathrm{Al}_{2} \mathrm{O}_{3}(\mathrm{c})+3 \mathrm{BeCl}_{2}$ (c) $=2 \mathrm{AlCl}_{3}(\mathrm{c})+3 \mathrm{BeO}(\mathrm{c})$

(2) $\mathrm{Al}_{2} \mathrm{O}_{3}(\mathrm{c})+6 \mathrm{LiCl}(\mathrm{l})=2 \mathrm{AlCl}_{3}(\mathrm{c})+3 \mathrm{Li}_{2} \mathrm{O}(\mathrm{c})$

(3) $\mathrm{Al}_{2} \mathrm{O}_{3}(\mathrm{c})+3 \mathrm{MgCl}_{2}(\mathrm{l})=2 \mathrm{AlCl}_{3}(\mathrm{c})+3 \mathrm{MgO}(\mathrm{c})$

(4) $\mathrm{BeO}(c)+2 \mathrm{LiCl}(l)=\mathrm{BeCl}_{2}(c)+\mathrm{Li}_{2} \mathrm{O}(\mathrm{c})$

(5) $\mathrm{BeO}(c)+\mathrm{MgCl}_{2}(l)=\mathrm{BeCl}_{2}(c)+\mathrm{MgO}(\mathrm{c})$

(6) $\mathrm{Li}_{2} \mathrm{O}(\mathrm{c})+\mathrm{MgCl}_{2}(l)=2 \mathrm{LiCl}(l)+\mathrm{MgO}(\mathrm{c})$

B. Gibbs Free Energies of Reaction (Calories)

Temperature (K)

$\begin{array}{rrrrrrr}\text { Reaction } & \underline{800} & \underline{900} & \underline{1000} & \underline{100} & \underline{1200} & \underline{1300} \\ \text { (1) } & -30,221 & -26,858 & -23,514 & -20,193 & -16,873 & -13,562 \\ (2) & 214,577 & 211,342 & 208,387 & 205,605 & 203,030 & 200,540 \\ (3) & 72,785 & 67,725 & 62,869 & 58,203 & 53,727 & 49,430 \\ (4) & 81,599 & 79,400 & 77,300 & 75,266 & 73,301 & 71,367 \\ (5) & 34,335 & 31,528 & 28,794 & 26,132 & 23,533 & 20,997 \\ (6) & -47,264 & -47,872 & -48,506 & -49,134 & -49,768 & -50,370\end{array}$

C. Summary of Stabilities at $1300 \mathrm{~K}(\mathrm{x}=$ stable $)$

\begin{tabular}{l|c|c|c|r|} 
& $\mathrm{AlCl}_{3}$ & $\mathrm{BeCl}_{2}$ & $\mathrm{MgCl}_{2}$ & $\mathrm{LiCl}$ \\
\hline $\mathrm{Al}_{2} \mathrm{O}_{3}$ & $\mathrm{X}$ & 0 & $\mathrm{X}$ & $\mathrm{x}$ \\
\hline $\mathrm{BeO}$ & $\mathrm{X}$ & $\mathrm{X}$ & $\mathrm{x}$ & $\mathrm{x}$ \\
\hline $\mathrm{MgO}$ & 0 & 0 & $\mathrm{X}$ & $\mathrm{X}$ \\
\hline $\mathrm{Li}_{2} \mathrm{O}$ & 0 & 0 & 0 & $\mathrm{x}$ \\
\hline
\end{tabular}




\section{FIGURES}

Figure 1. Knudsen effusion mass spectrometric data for thermal decomposition of $\mathrm{ClO}_{3} \mathrm{~F}$.

Figure 2. Schematic of high pressure transpiration mass spectrometer cell.

Figure 3. High pressure transpiration mass spectrometer data for thermal decomposition of $\mathrm{ClO}_{3} \mathrm{~F}$.

Figure 4. Total pressure in high pressure transpiration mass spectrometer system as a function of temperature. Break in slope indicates beginning of $\mathrm{ClO}_{3} \mathrm{~F}$ decomposition.

Figure 5. Ion current data for ${ }^{35} \mathrm{ClO}_{3}{ }^{+}$in $\mathrm{ClO}_{3} \mathrm{~F} /$ transpiration mass spectrometer experiment of Figs. 3,4 .

Figure 6. Thermogravimetric curve for fluorine saturation of alumina cell by $\mathrm{ClO}_{3} \mathrm{~F}$ at $800^{\circ} \mathrm{C}$.

Figure 7. Thermogravimetric data for reaction of $0.3 \mu \mathrm{m}$ alumina powder with $\mathrm{ClO}_{3} \mathrm{~F}$ at various temperatures.

Figure 8. Thermogravimetric data for effect of $\mathrm{ClO}_{3} \mathrm{~F}$ flow rate on $0.3 \mu \mathrm{m}$ alumina reaction at $800^{\circ} \mathrm{C}$.

Figure 9. Plot of rate constants for $\mathrm{ClO}_{3} \mathrm{~F} / \mathrm{Al}_{2} \mathrm{O}_{3}$ reaction data of Figs. 7 and 8 .

Figure 10. Thermogravimetric data for fluorine saturation of $\mathrm{MgO}$ cell by $\mathrm{ClO}_{3} \mathrm{~F}$ at $800^{\circ} \mathrm{C}$.

Figure 11. Melted aluminum ball of type used in reaction rate studies.

Figure 12. Surface of aluminum ball after reaction with $\mathrm{ClO}_{3} \mathrm{~F}$ at $800^{\circ} \mathrm{C}$.

Figure 13. Surface of aluminum ball after $\mathrm{ClO}_{3} \mathrm{~F}$ reaction, showing surface channel under gas jet.

Figure 14. Thermogravimetric data for reaction of molten aluminum ball with $\mathrm{ClO}_{3} \mathrm{~F}$ at various temperatures.

Figure 15. Thermogravimetric data for effect of $\mathrm{ClO}_{3} \mathrm{~F}$ flow rate on aluminum reaction at $800^{\circ} \mathrm{C}$.

Figure 16. Cooling curve for tungsten furnace used in $\mathrm{Li}_{2} \mathrm{O}-\mathrm{Al}_{2} \mathrm{O}_{3}$ phase equilibrium experiments.

Figure 17. Equilibrium crystals of $\mathrm{LiAl}_{5} \mathrm{O}_{8}$ spinel with recrystallized interstitial eutectic melt.

Figure 18. Phase diagram for the high alumina portion of the system $\mathrm{LiAlO}_{2}-\mathrm{Al}_{2} \mathrm{O}_{3}$.

Figure 19. Lamellar intergrowths in $\left(\mathrm{Li}_{2} \mathrm{O}_{2.5}\left(\mathrm{Al}_{2} \mathrm{O}_{3}\right)_{97.5}\right.$ cooled from $1925^{\circ} \mathrm{C}$.

Figure 20. DTA analysis of phase transition in $\mathrm{LiAl}_{4} \mathrm{O}_{2}$. 
Figure 25. Chemical equilibria of chlorides formed by reaction with LiMgAl alloy.

Figure 26. Chemical equilibria of $(\mathrm{Mg}, \mathrm{Al})$ chlorides formed by reaction with LiMgAl alloy.

Figure 27. Chemical equilibria of ( $\mathrm{Li}, \mathrm{Mg}$ ) fluorides formed by reaction with LiMgal alloy.

Figure 28. Chemical equilibria of ( $\mathrm{Li}, \mathrm{Al}$ ) fluorides formed by reaction with LiMgAl alloy.

Figure 29. Partitioning of fluorine in the lithium molten salt phase.

Figure 30. Partitioning of fluorine in the magnesium molten salt phase.

Figure 31. Vapor pressure over molten lithium and over $\mathrm{Li}+\mathrm{LiH}$ mixture.

Figure 32. Vapor pressures over $\mathrm{LiOH}$ and over $\mathrm{LiOH}+\mathrm{Li}_{2} \mathrm{O}$ mixture.

Figure 33. Partial pressures of Lithium species over their respective condensed phases.

Figure 34. Partial pressures of aluminum species over their respective condensed phases.

Figure 35. Partial pressures of beryllium species over their respective condensed phases.

Figure 36. Partial pressures of magnesium species over their respective condensed phases. 


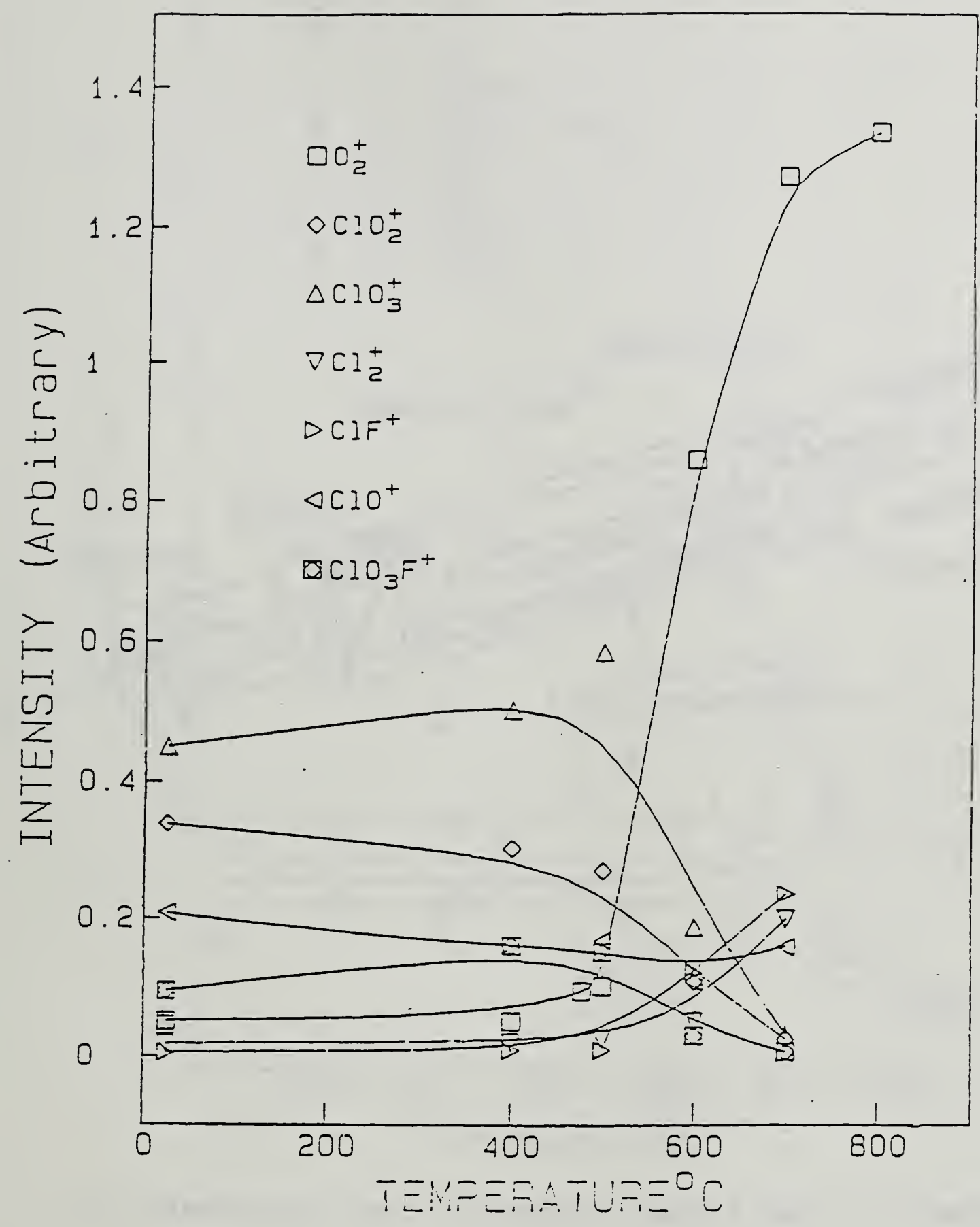

Figure 1. Knudsen effusion mass spectrometric ion intensity data for thermal decomposition of $\mathrm{ClO}_{3} \mathrm{~F}$. 


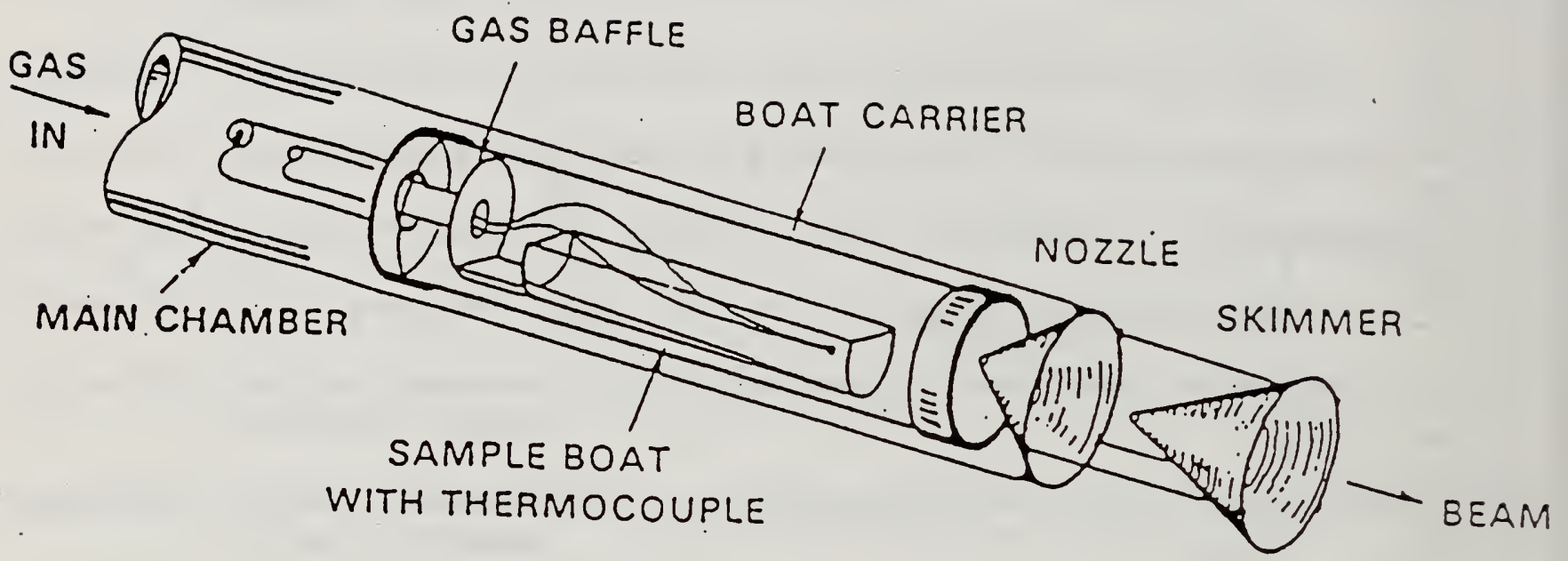

Figure 2. Schematic of high pressure transpiration mass spectrometer cell. 


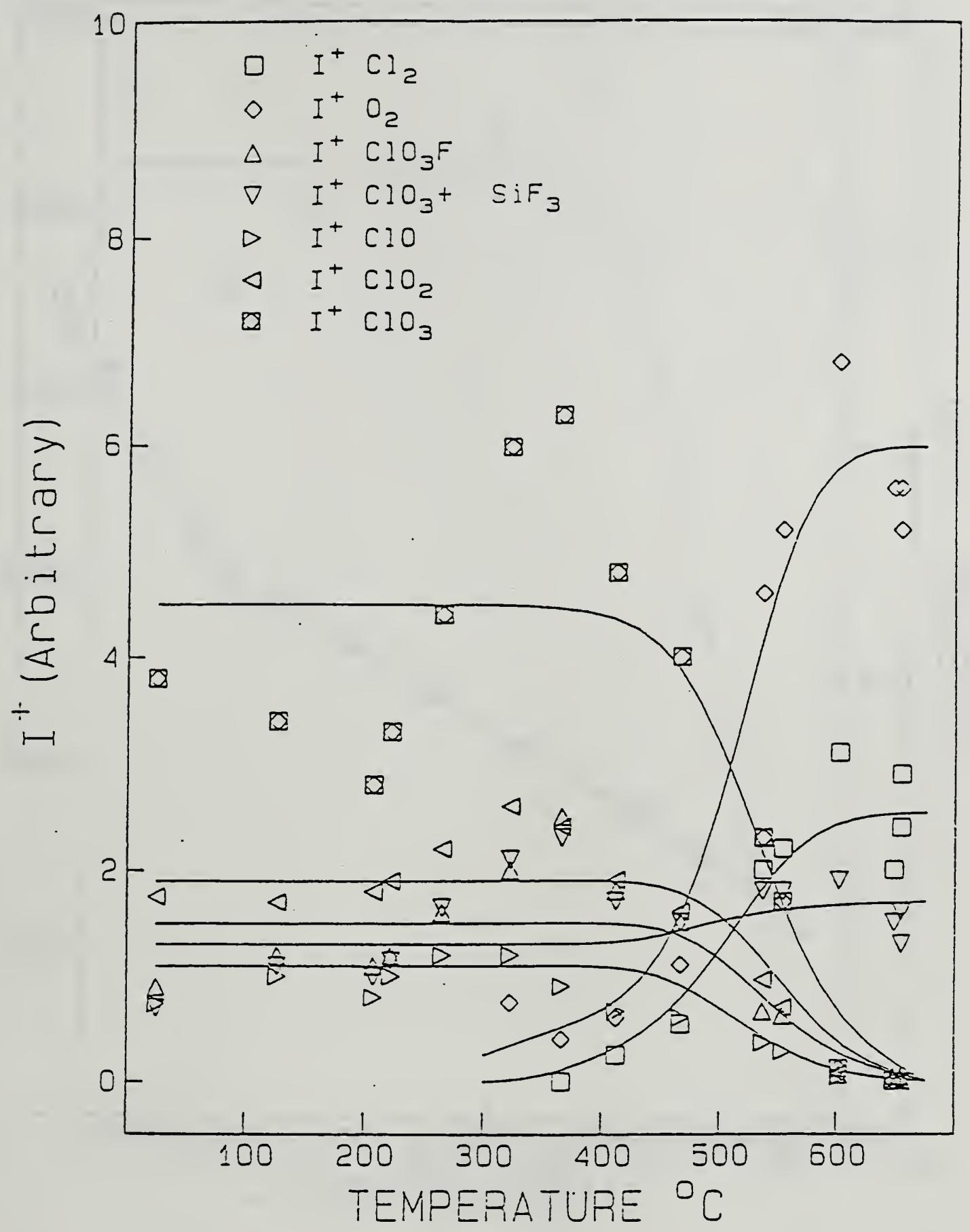

Figure 3. High pressure transpiration mass spectrometer ion intensity data for thermal decomposition of $\mathrm{ClO}_{3} \mathrm{~F}$. 


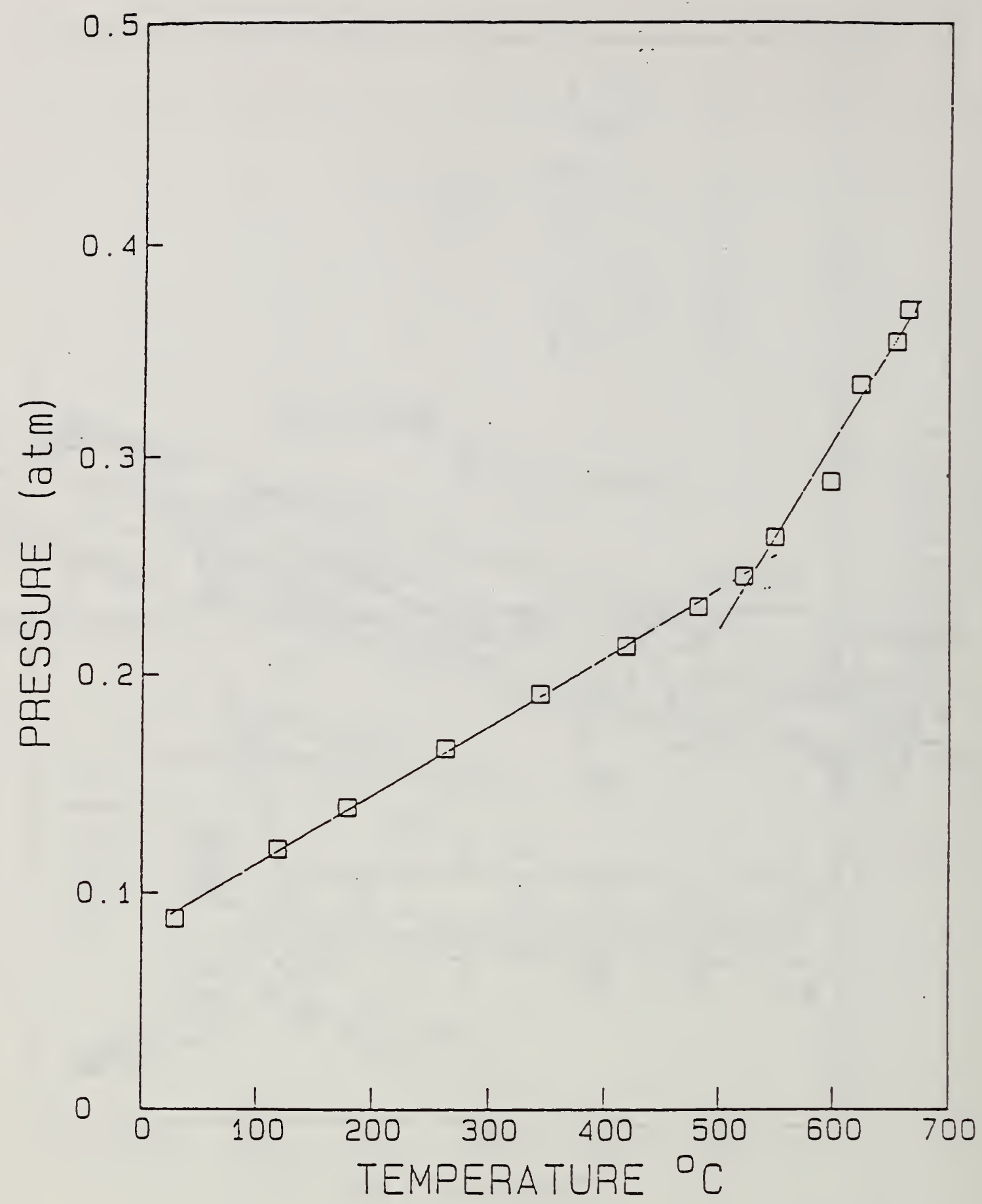

Eigure 4. Total pressure in high pressure transpiration mass spectrometer system as a function of temperature. Break in slope incicares beginning of $\mathrm{ClO}_{3} \mathrm{~F}$ decomposition. 


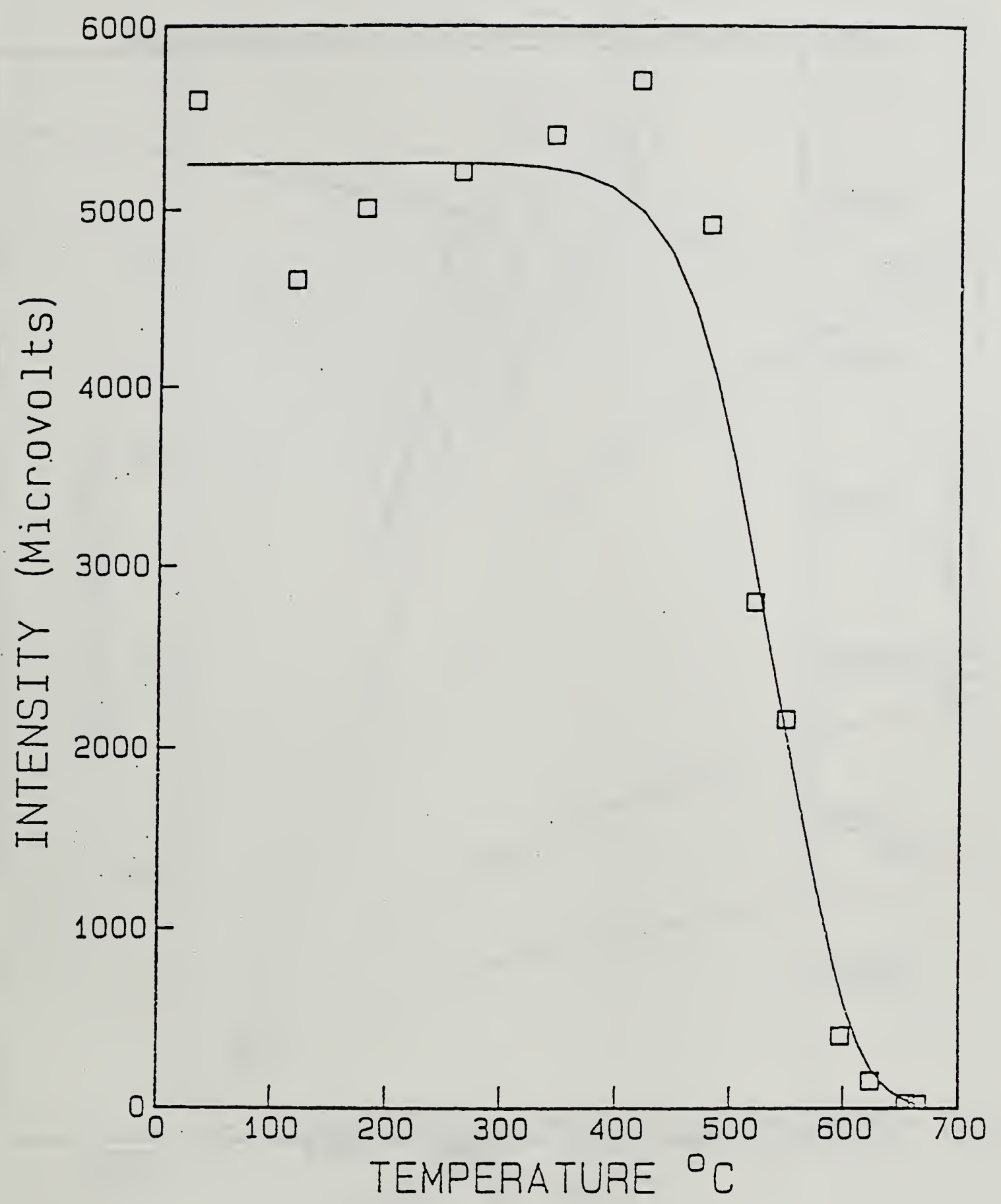

igure 5. Ion current data for ${ }^{35} \mathrm{ClO}_{3}{ }^{+}$in $\mathrm{ClO}_{3} \mathrm{~F} /$ transpiration mass spectrometer experiment of Figs. 3,4 . 


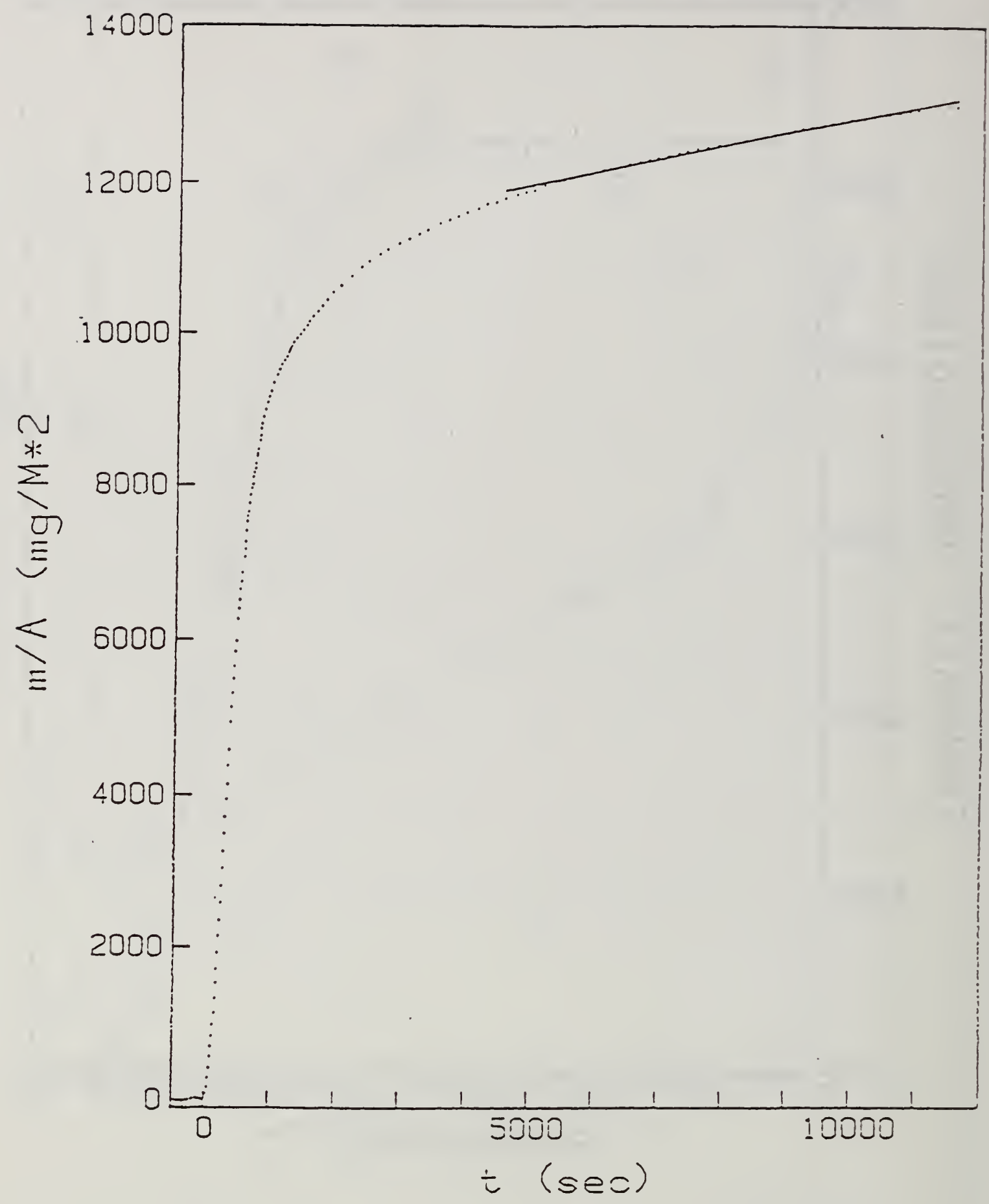

Eigure 6. Thezmogravimetzic curve for Eluorine satuzation of alumina cell by $\mathrm{ClO}_{3} \overline{\mathrm{F}} \mathrm{a}=800^{\circ} \mathrm{C}$. 


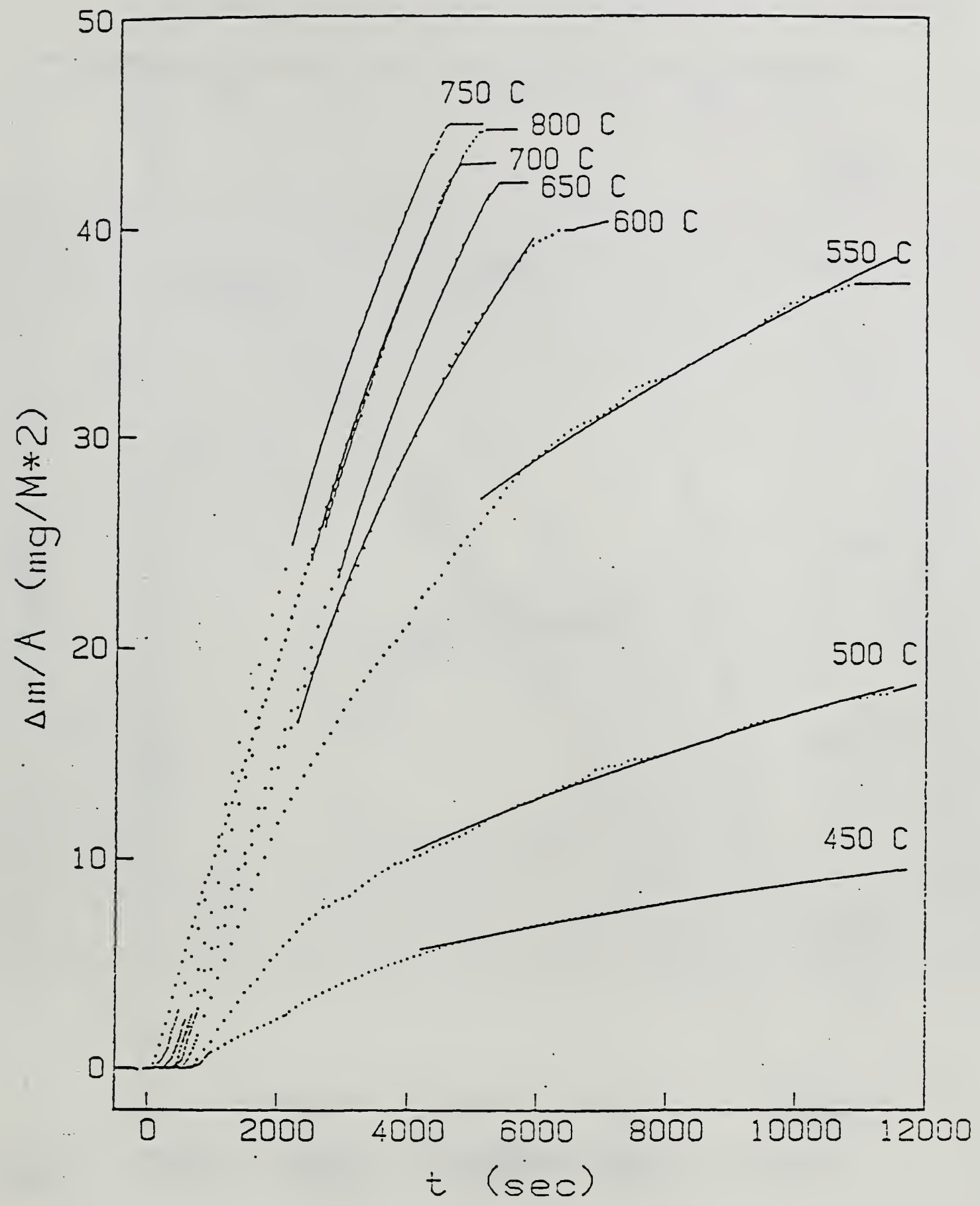

igure 7. Thermogravimetric data for reaction of $0.3 \mu \mathrm{m}$ alumina powder with $\mathrm{ClO}_{3} \mathrm{~F}$ at various temperatures. 


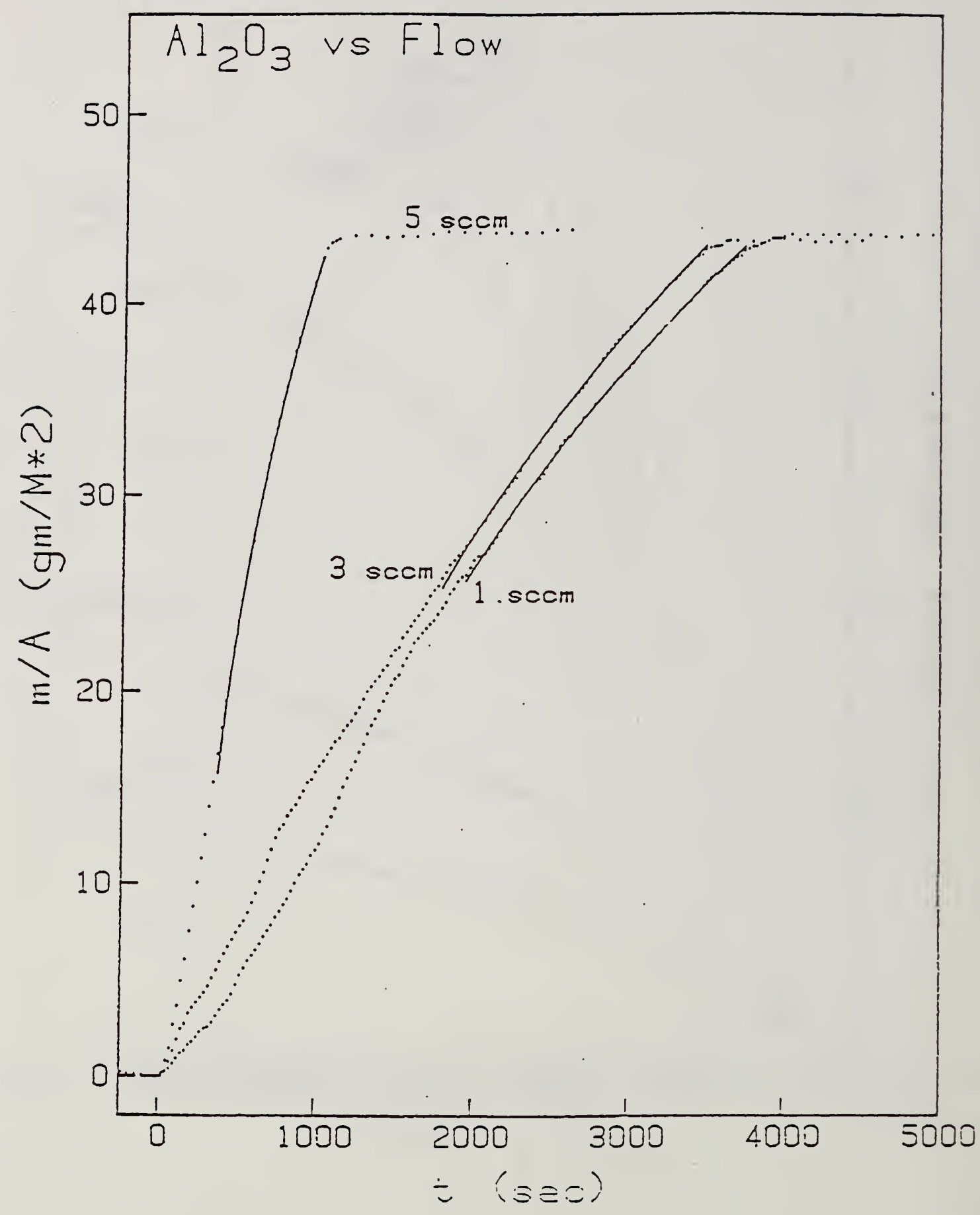

Figure 8. Thermogravimetric data for effect of $\mathrm{ClO}_{3} \mathrm{~F}$ flow rate on its reaction with $0.3 \mu \mathrm{m}$ alumina at $800^{\circ} \mathrm{C}$. 


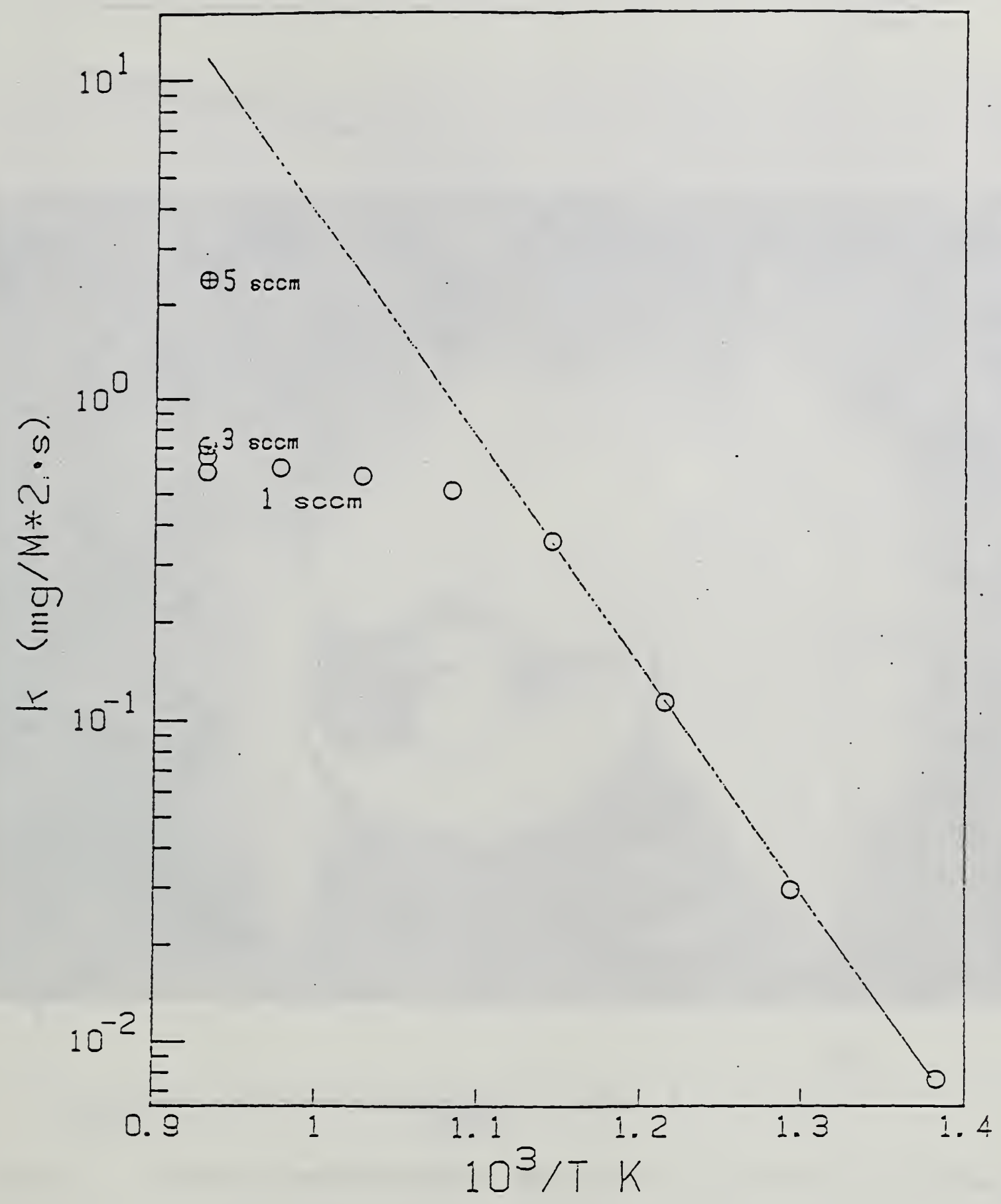

Figure 9. Rate constants for $\mathrm{ClO}_{3} \mathrm{~F} / \mathrm{Al}_{2} \mathrm{O}_{3}$ reaction data of Figs. 7 and 8. 


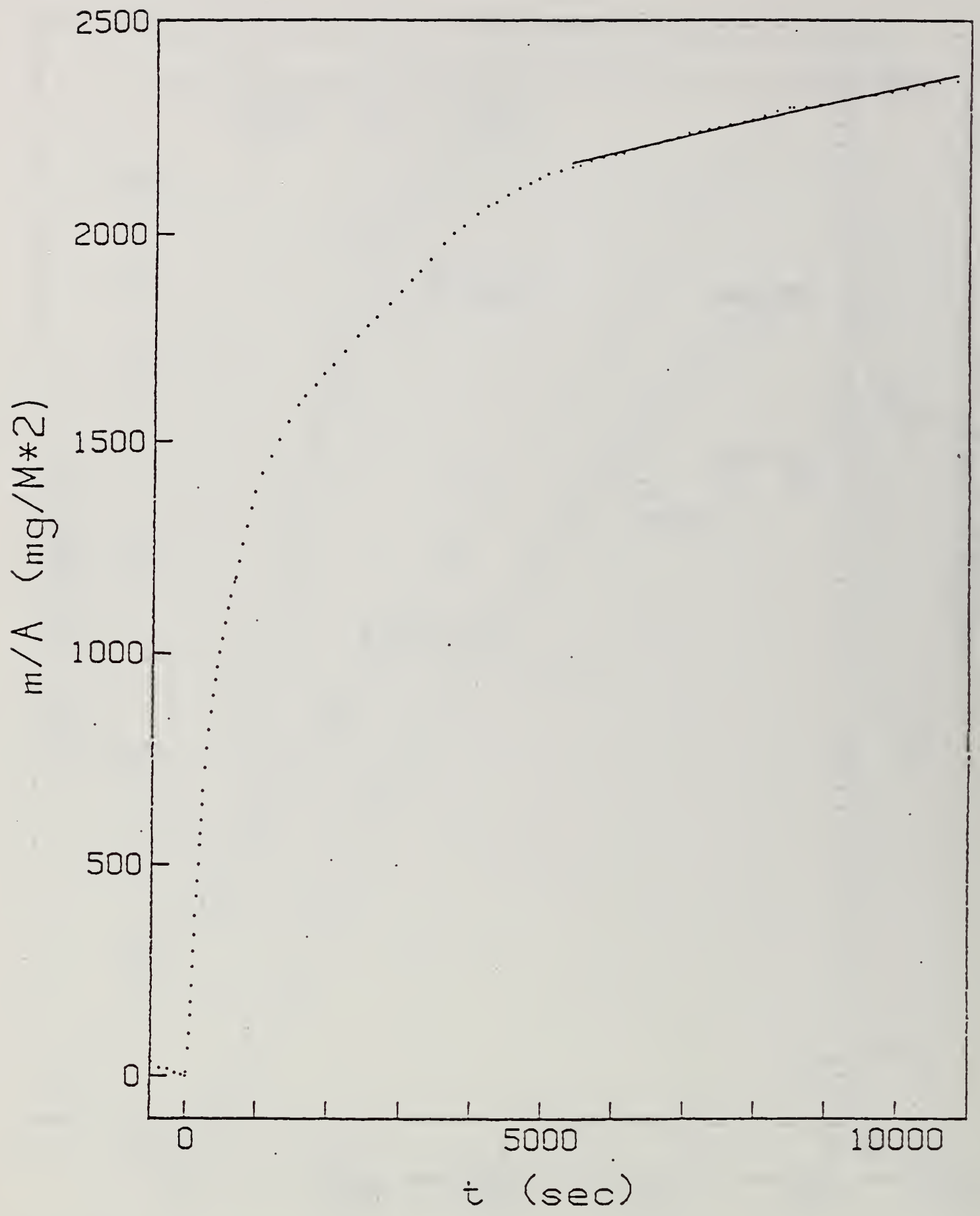
Figure 10. Thermogravimetric data for fluorine saturation of MgO cell by
$\mathrm{ClO}_{3} \mathrm{~F}$ at $800^{\circ} \mathrm{C}$. 


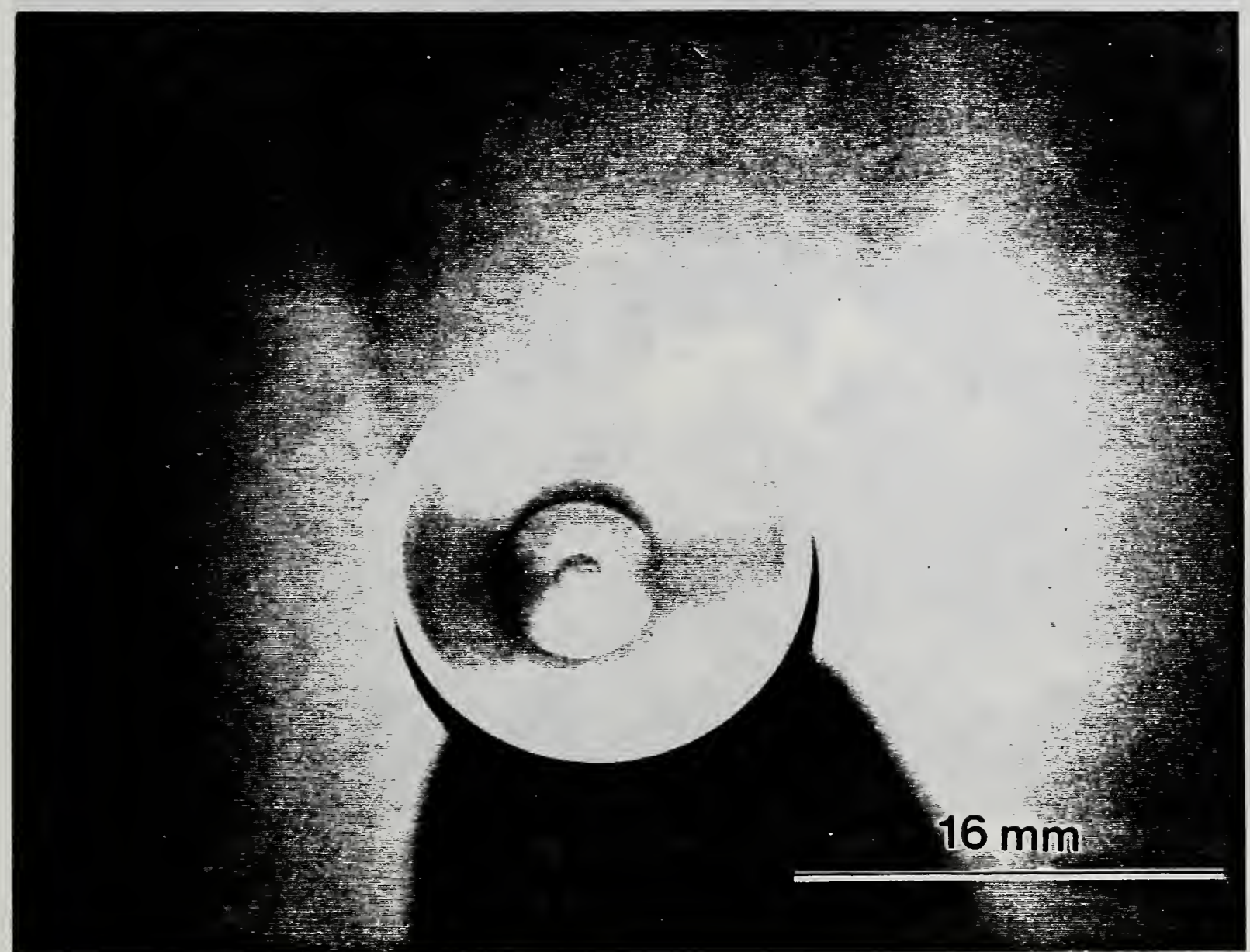

Figure 11. Melted aluminum ball of type used in reaction rate studies. 


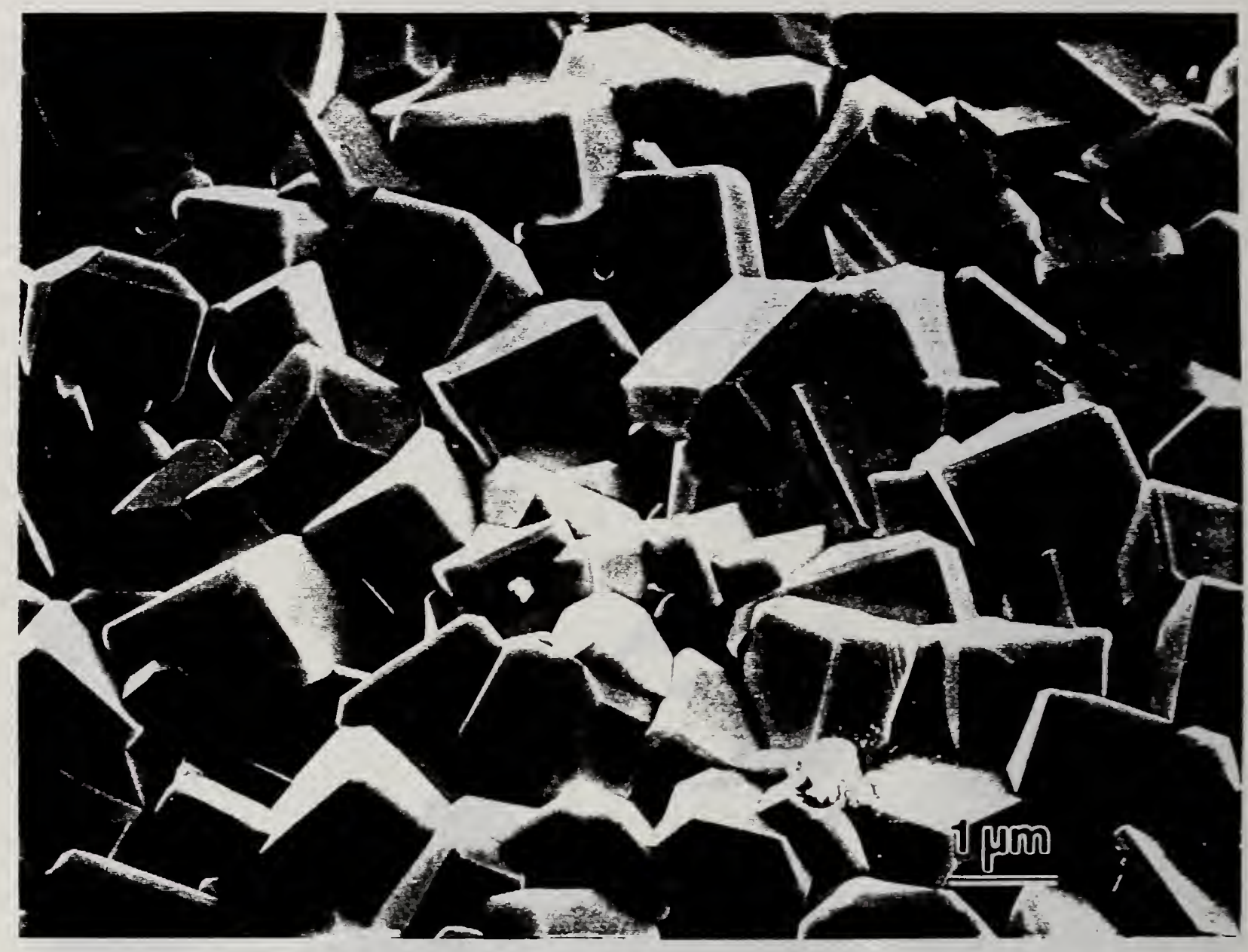

Figure 12. Surface of aluminum ball after reaction with $\mathrm{ClO}_{3} \mathrm{~F}$ at $800^{\circ} \mathrm{C}$. 


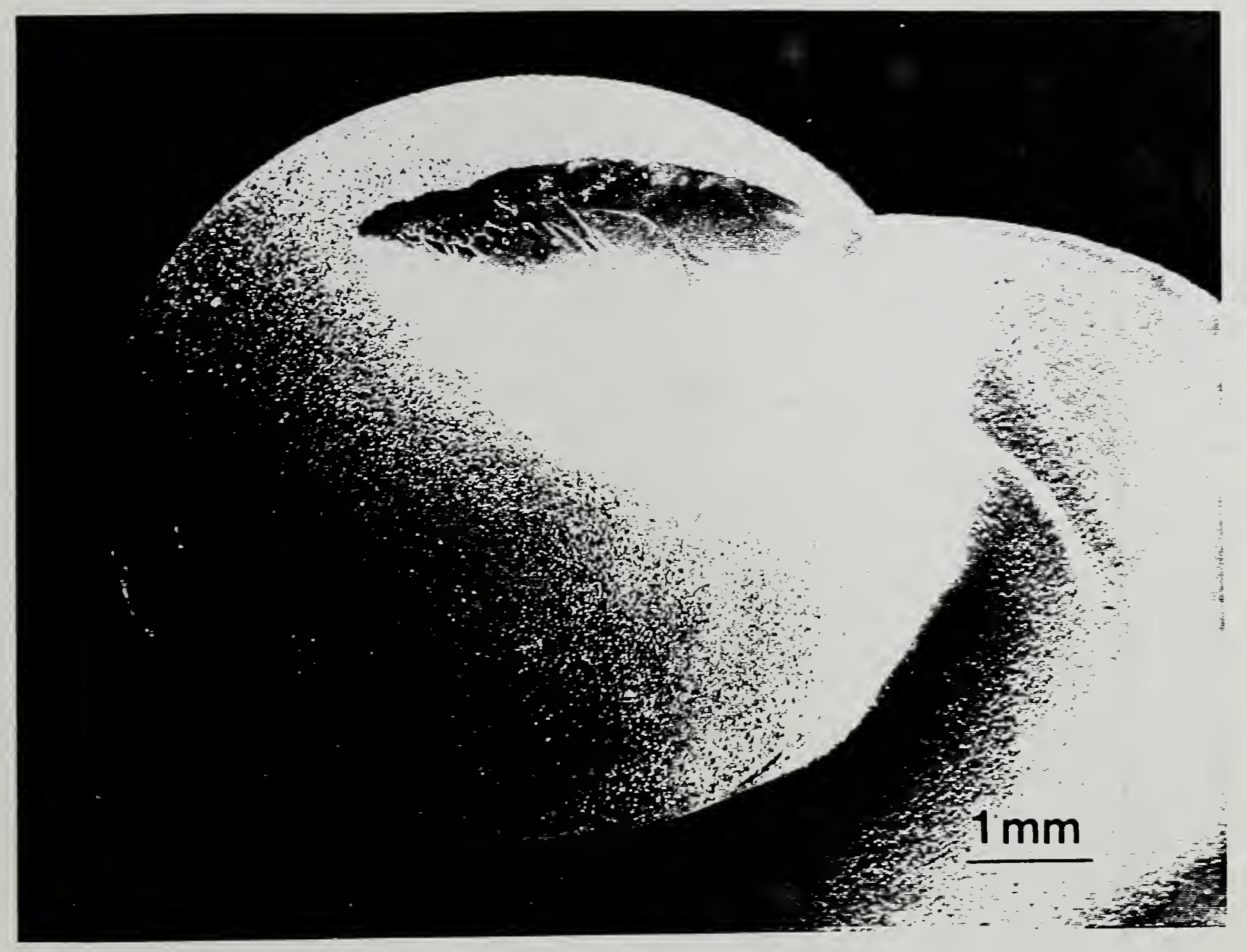

Figure 13. Surface of aluminum ball after $\mathrm{ClO}_{3} \mathrm{~F}$ reaction, showing surface channel under gas jet. 


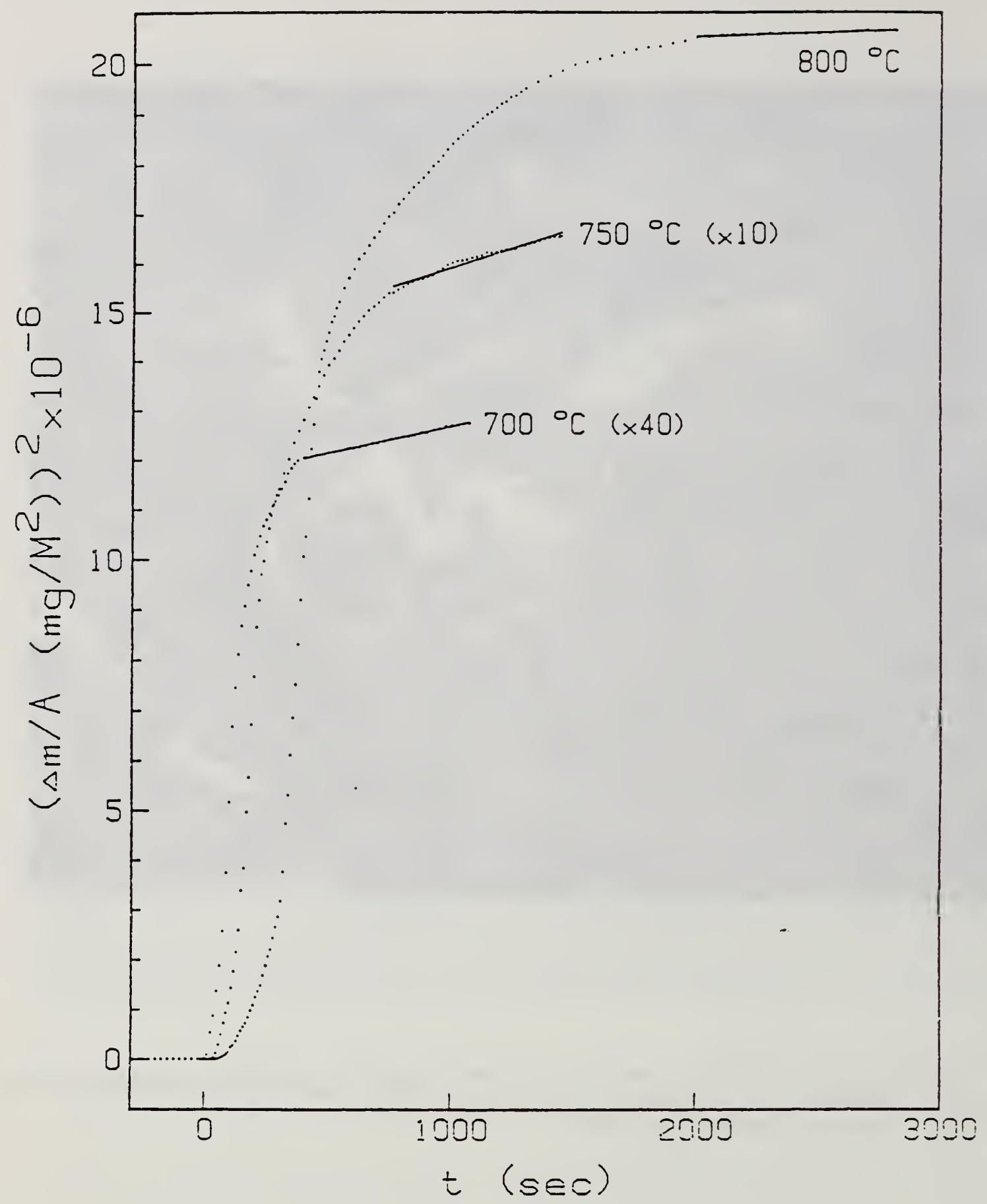

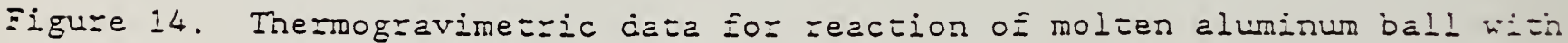
$\mathrm{ClO}_{3} \mathrm{~F}$ at various Lemperatures. 


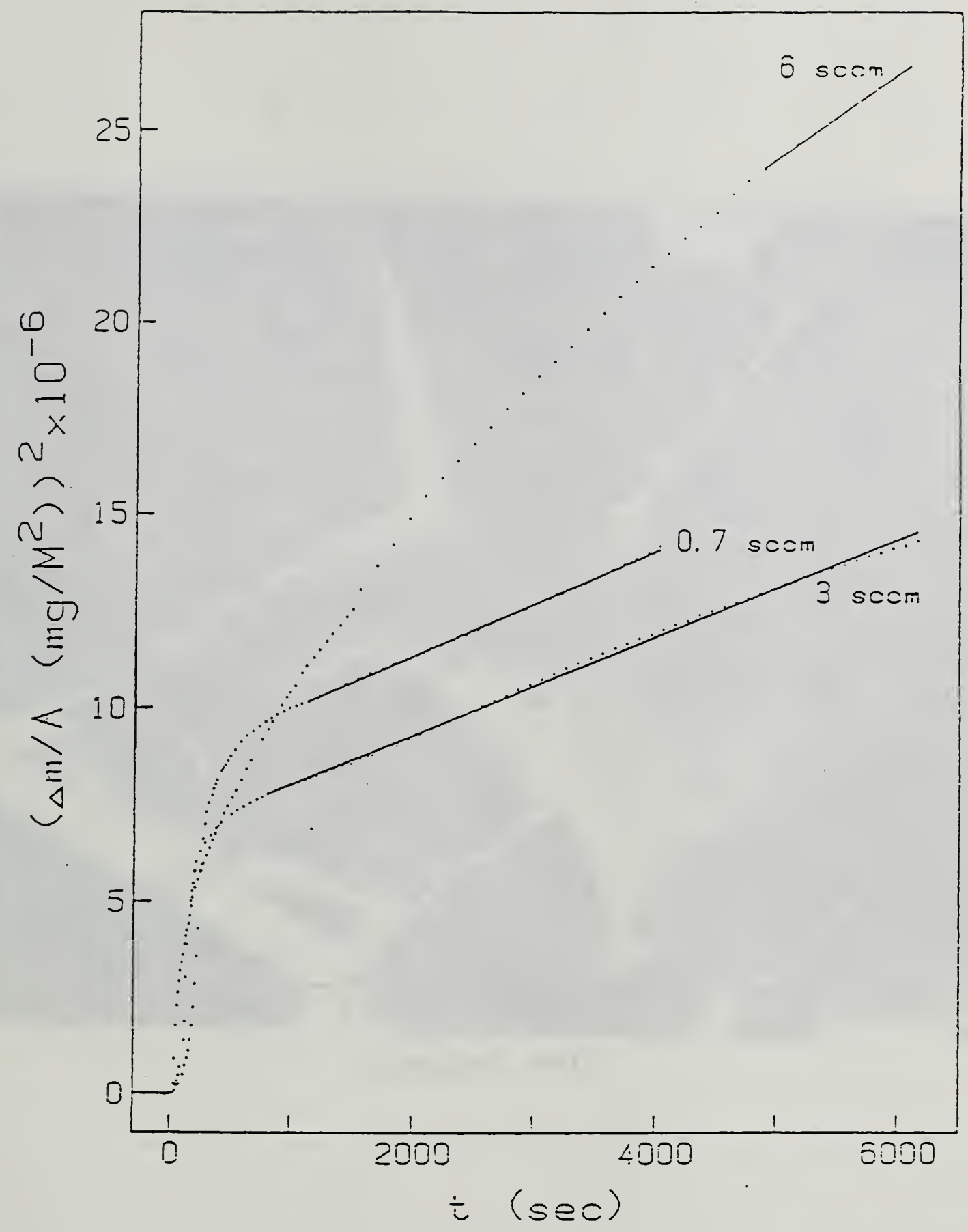

Figure 15. Thermogravimetric data for effect of $\mathrm{ClO}_{3}$ f flow rate on aluminum reaction at $800^{\circ} \mathrm{C}$. 


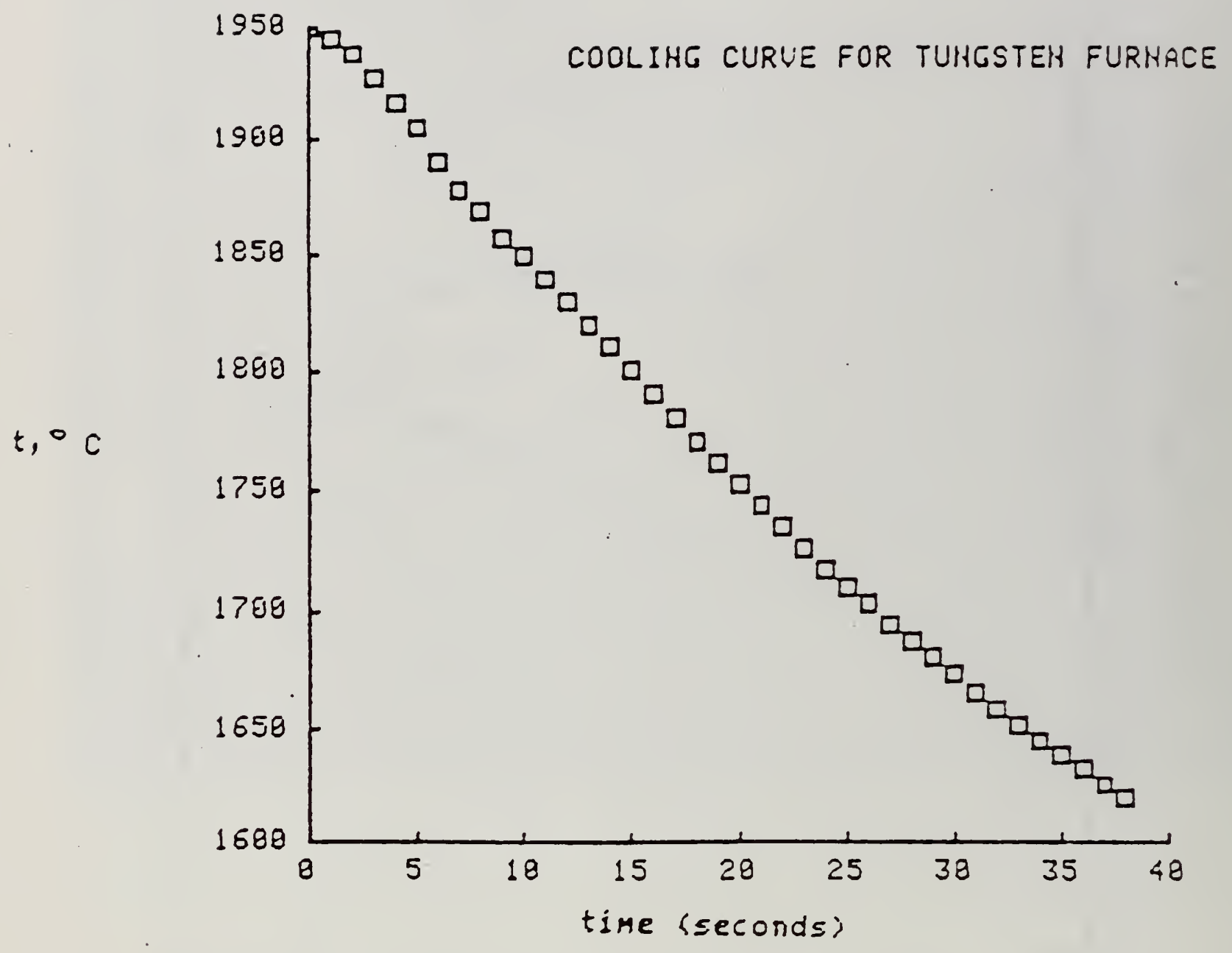

Figure 16: Cooling curve for tungsten furnace used in $\mathrm{Ii}_{2} \mathrm{O}-\mathrm{Al}_{2} \mathrm{O}_{3}$ phase equilibrium experiments. 


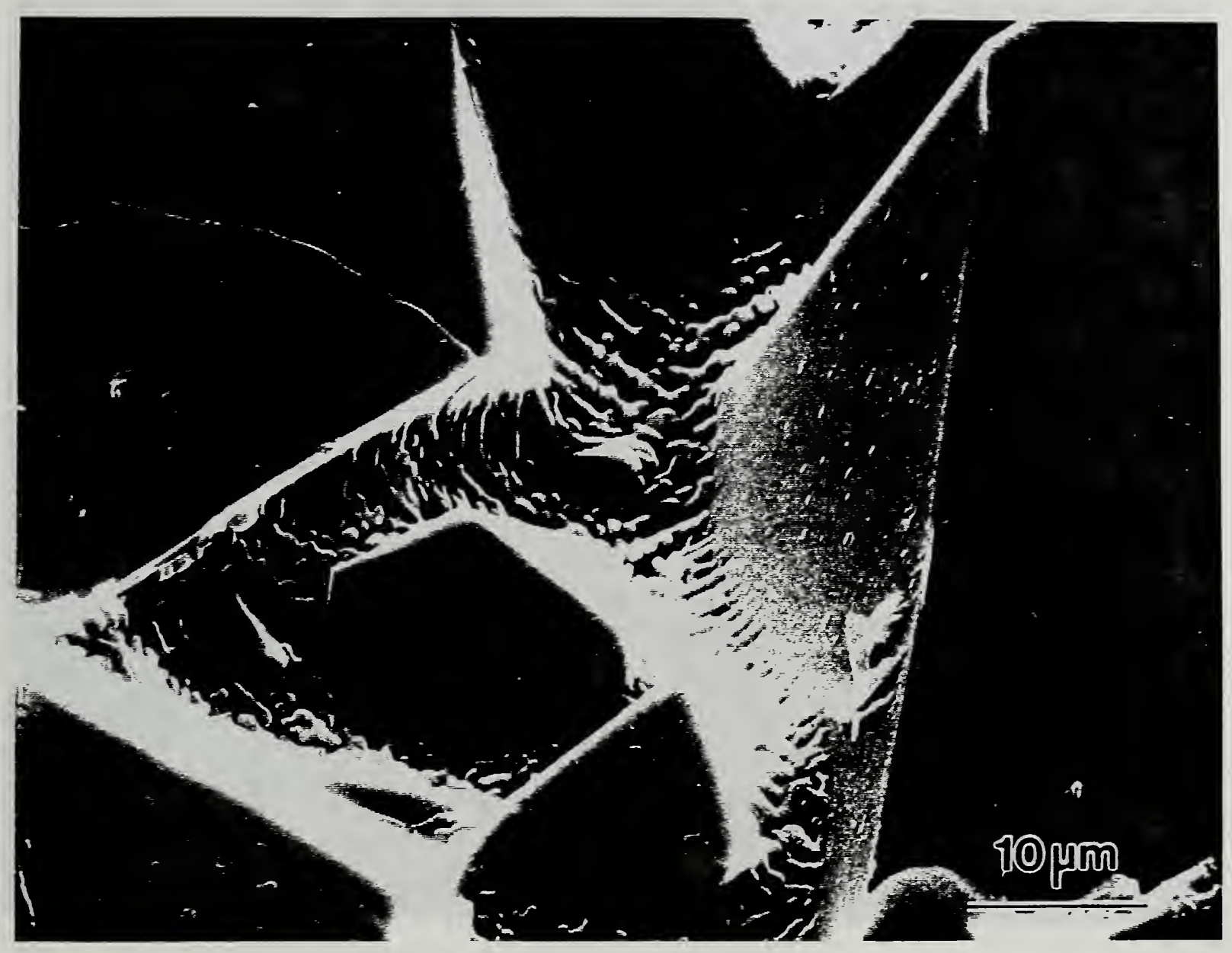

Eigure 17. Equilibrium crystals of $\mathrm{LiAl}_{5} \mathrm{O}_{8}$ spinel with recrystallized interstitial eutectic melt. 


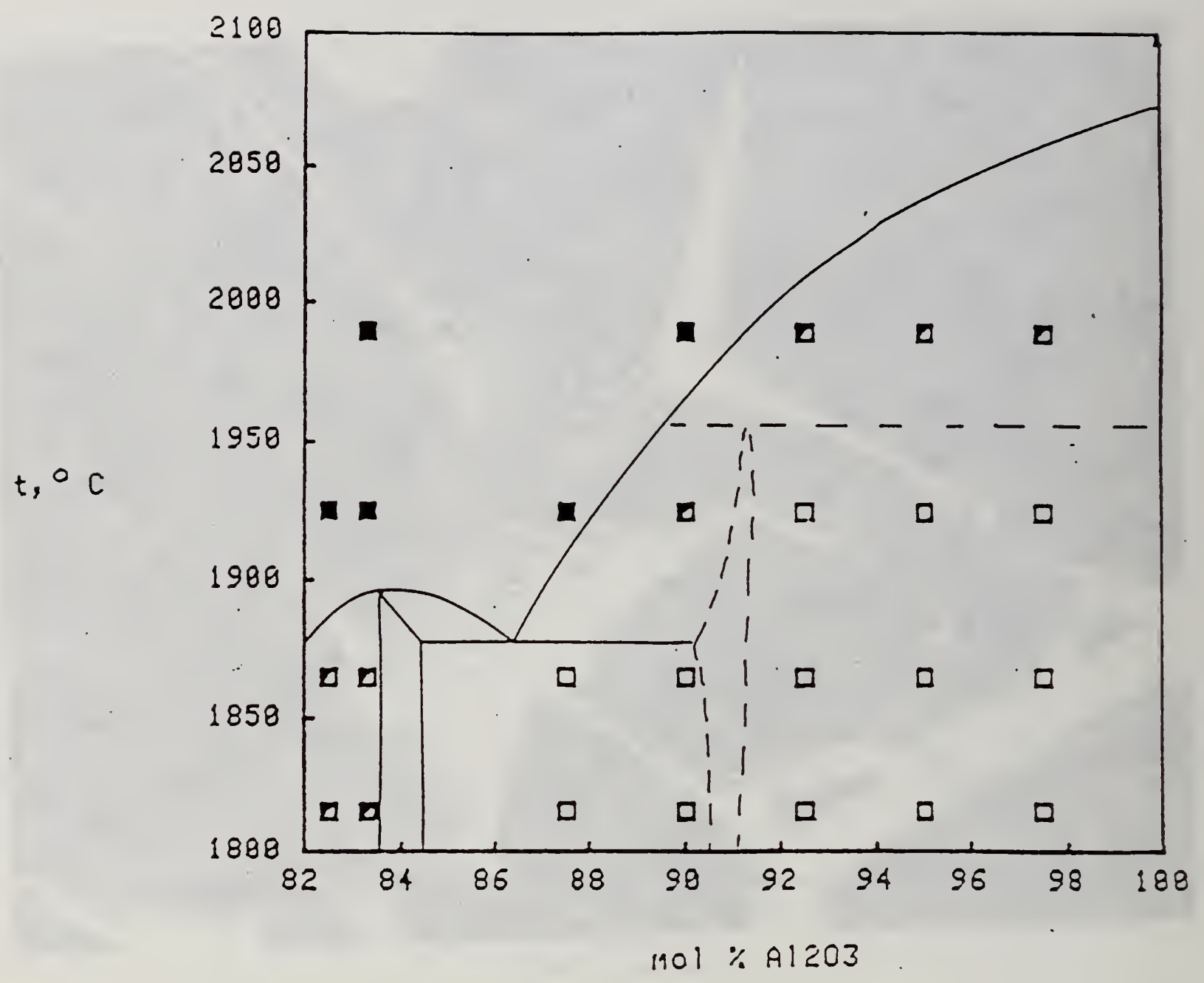

Figure 18. Phase diagram for the high alumina portion of the system $\mathrm{LiAlO}_{2}-\mathrm{AL}_{2} \mathrm{O}_{3}$. 


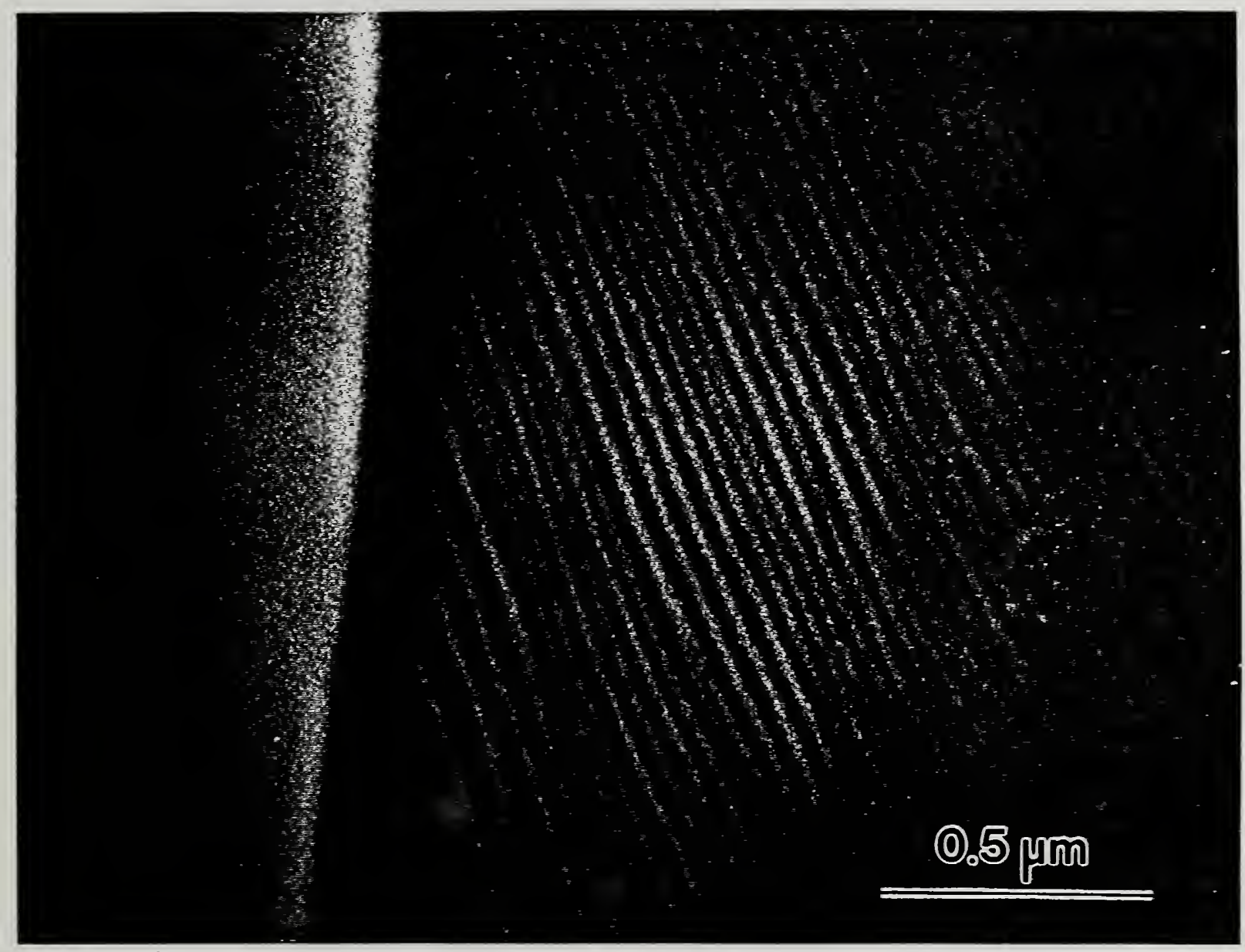

Eigure 19. Lamellar intergrowths in $\left(\mathrm{Li}_{2} \mathrm{O}\right)_{2.5}\left(\mathrm{Al}_{2} \mathrm{O}_{3}\right)_{\mathrm{g}} .5$ cooled from $1925^{\circ} \mathrm{C}$. 
1
$\vdots$
$E$
$\frac{1}{2}$
$\frac{1}{0}$
$\frac{0}{0}$
0

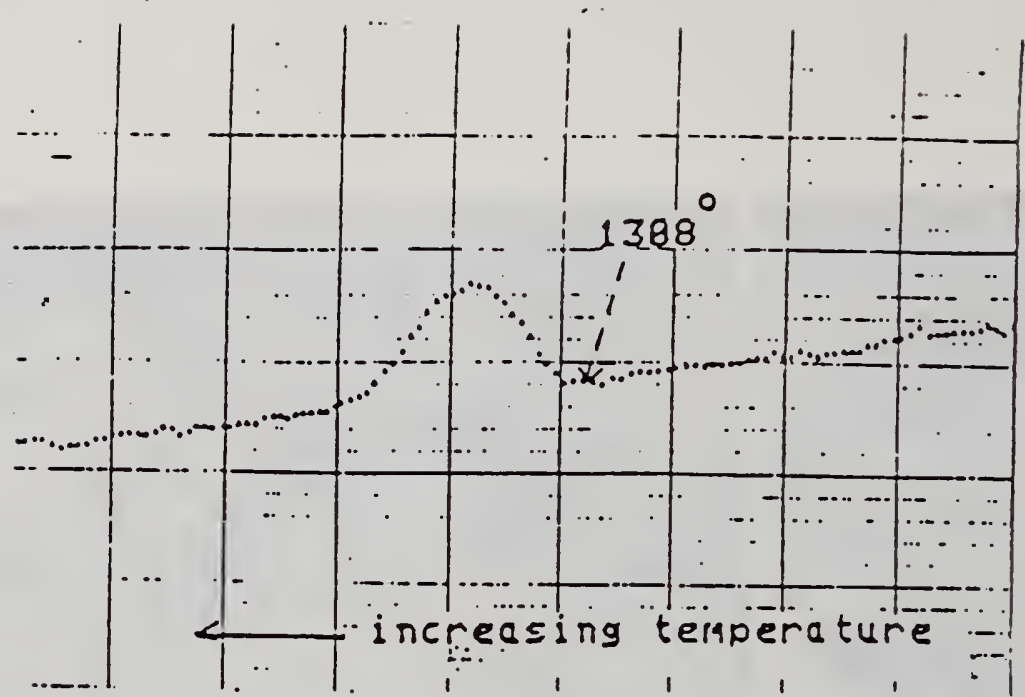

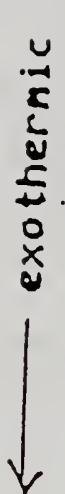

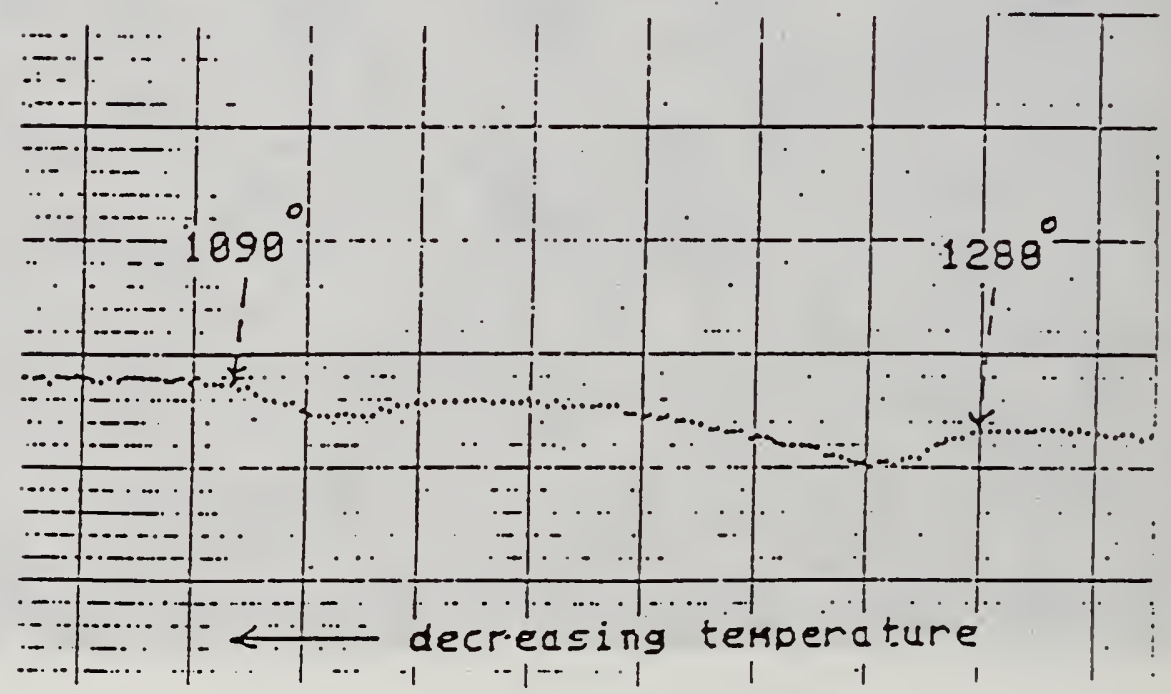

Figure 20. DTA analysis of phase transition in $\mathrm{LiAl}_{5} \mathrm{O}_{8}$. 


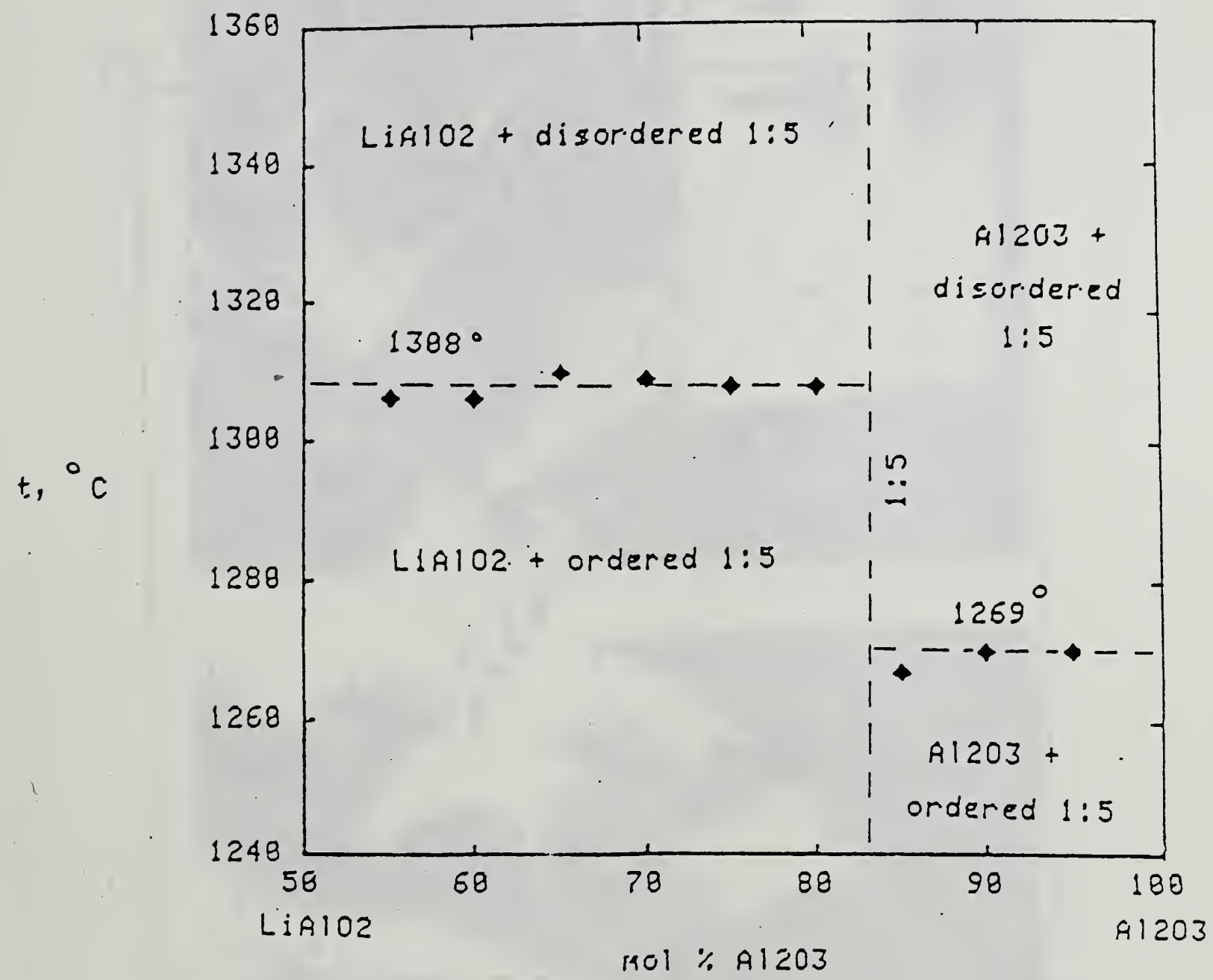

Figure 21. Effect of composition on $\mathrm{LiAl}_{5} \mathrm{O}_{8}$ transition. 


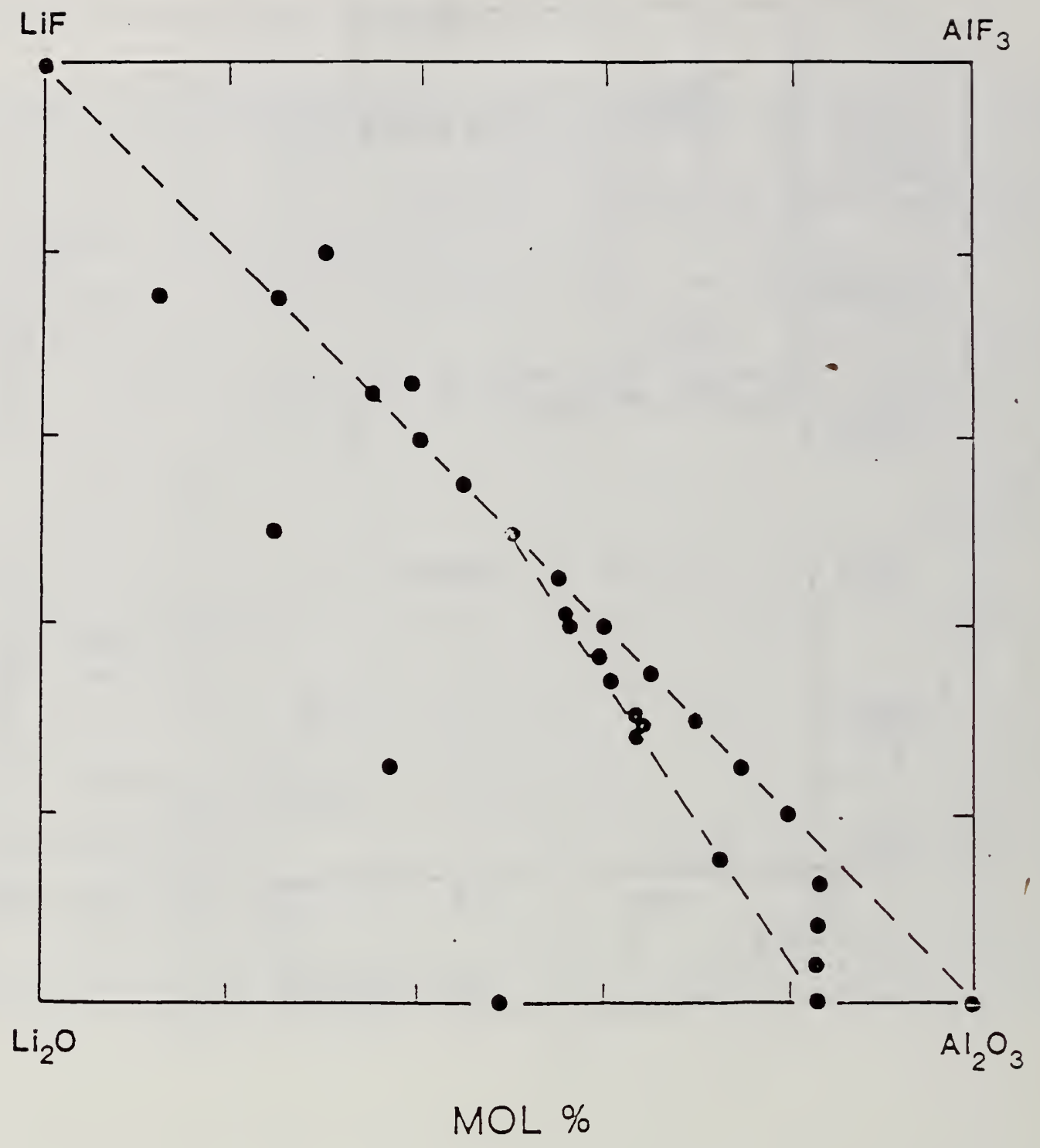

Figure 22. Compositions investigated in the system $\mathrm{Li}_{2} \mathrm{O}-\mathrm{Al}_{2} \mathrm{O}_{3}-\mathrm{A} I \mathrm{~F}_{3}-\mathrm{IiF}$. 

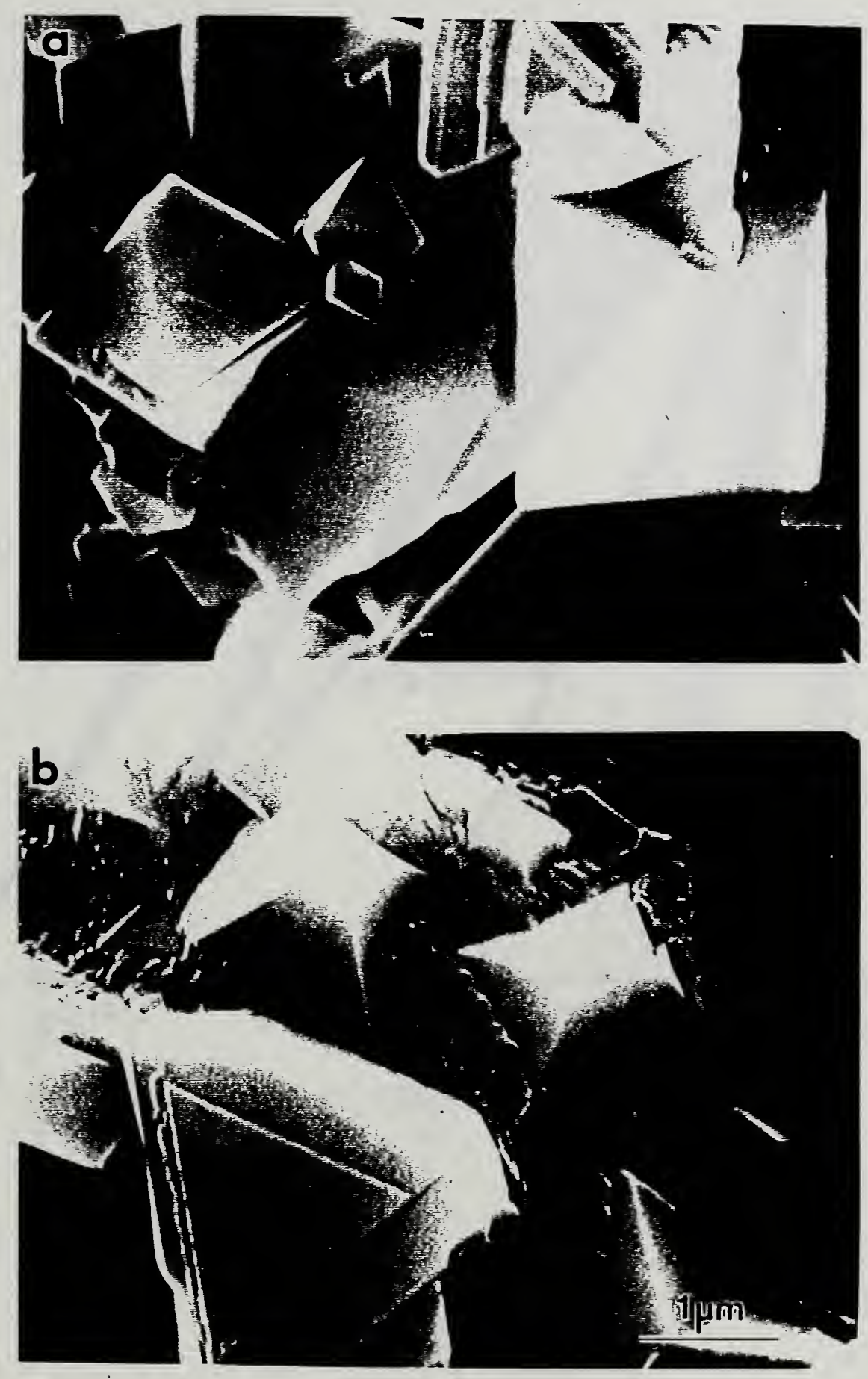

Figure 23. Effect of composition on meling at $1200^{\circ} \mathrm{C}$ in the system $\mathrm{Li}_{2} \mathrm{O}-\mathrm{Al}_{2} \mathrm{O}_{3}-\mathrm{AlF}_{3}-\mathrm{IiF}$. (a) composition $\mathrm{Li}_{7} \mathrm{Al}_{7} \mathrm{~F}_{6} \mathrm{O}_{26}$ showing absence of melt; (b) composition ( $I i F)_{50}\left(\mathrm{Al}_{2} \mathrm{O}_{3}\right)_{50}$ showing definite melting. 


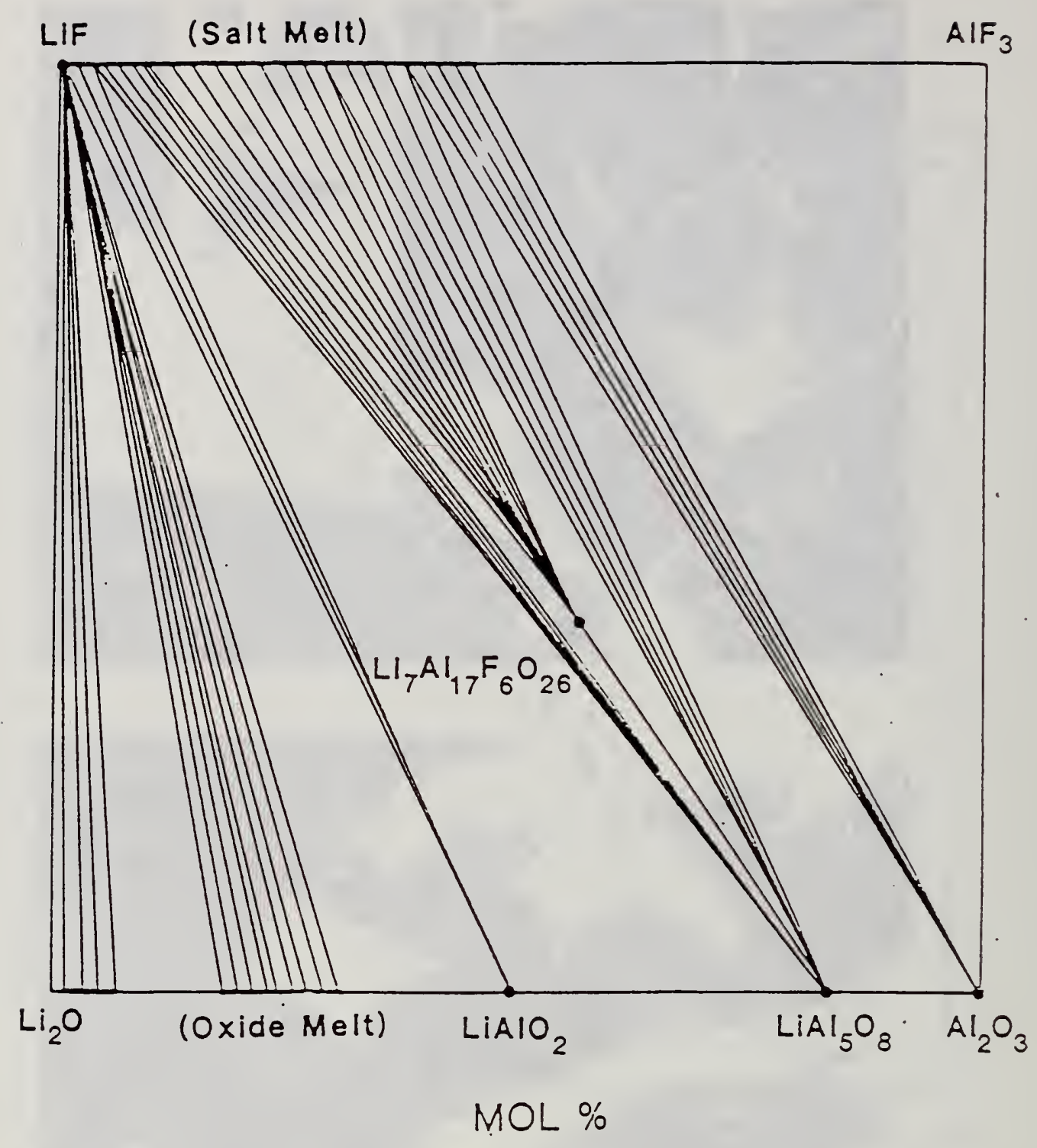

Figure 24. Phase relations in the system $\mathrm{Li}_{2} \mathrm{O}-\mathrm{Al}_{2} \mathrm{O}_{3}-\mathrm{AIF}_{3}-\mathrm{IiF}$ at $1200^{\circ} \mathrm{C}$. 


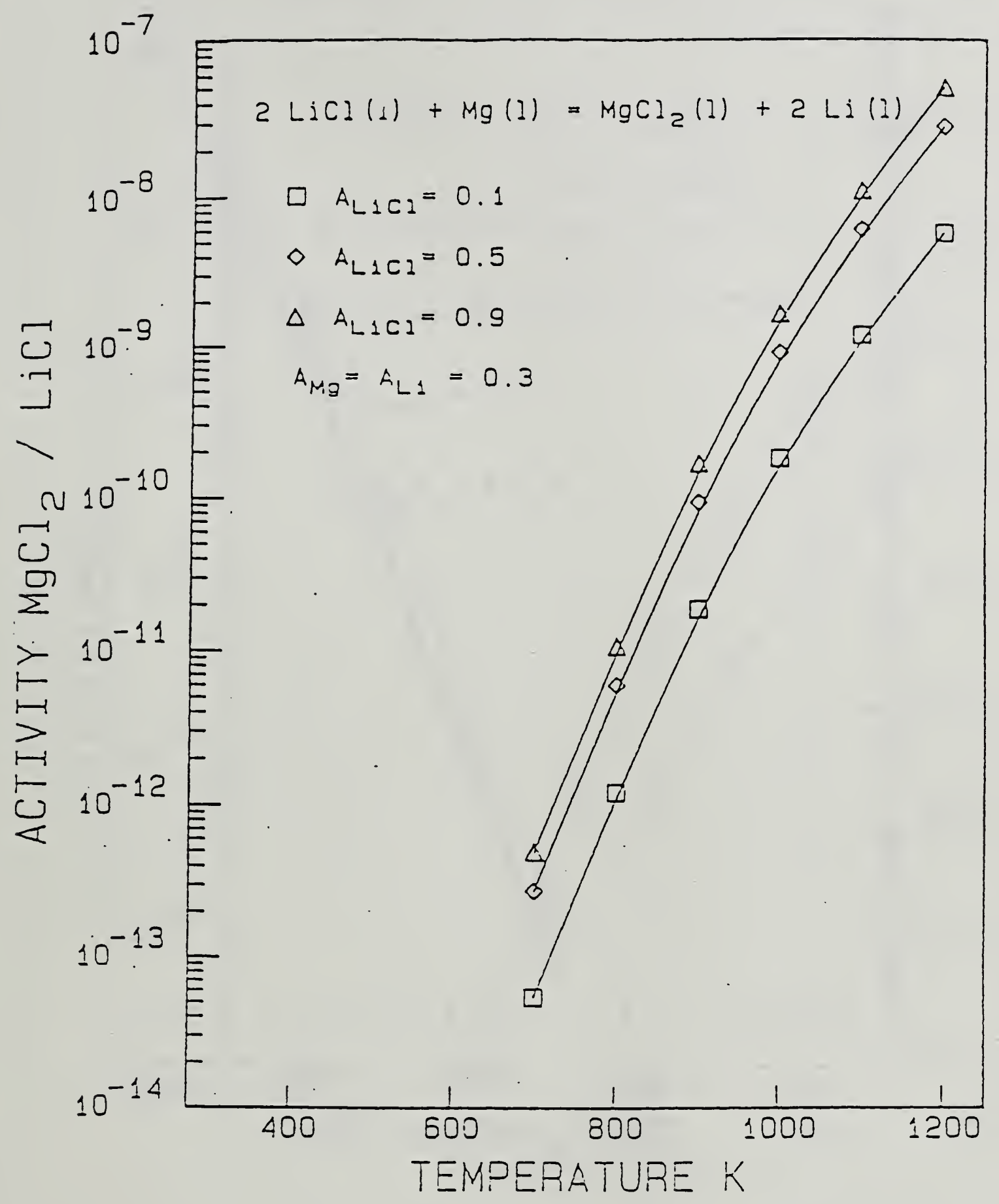

Figure 25. Calculated chemical equilibria of ( $\mathrm{Ii}, \mathrm{Mg}$ ) chlorides formed by reaction with LiMgAl alloy. 


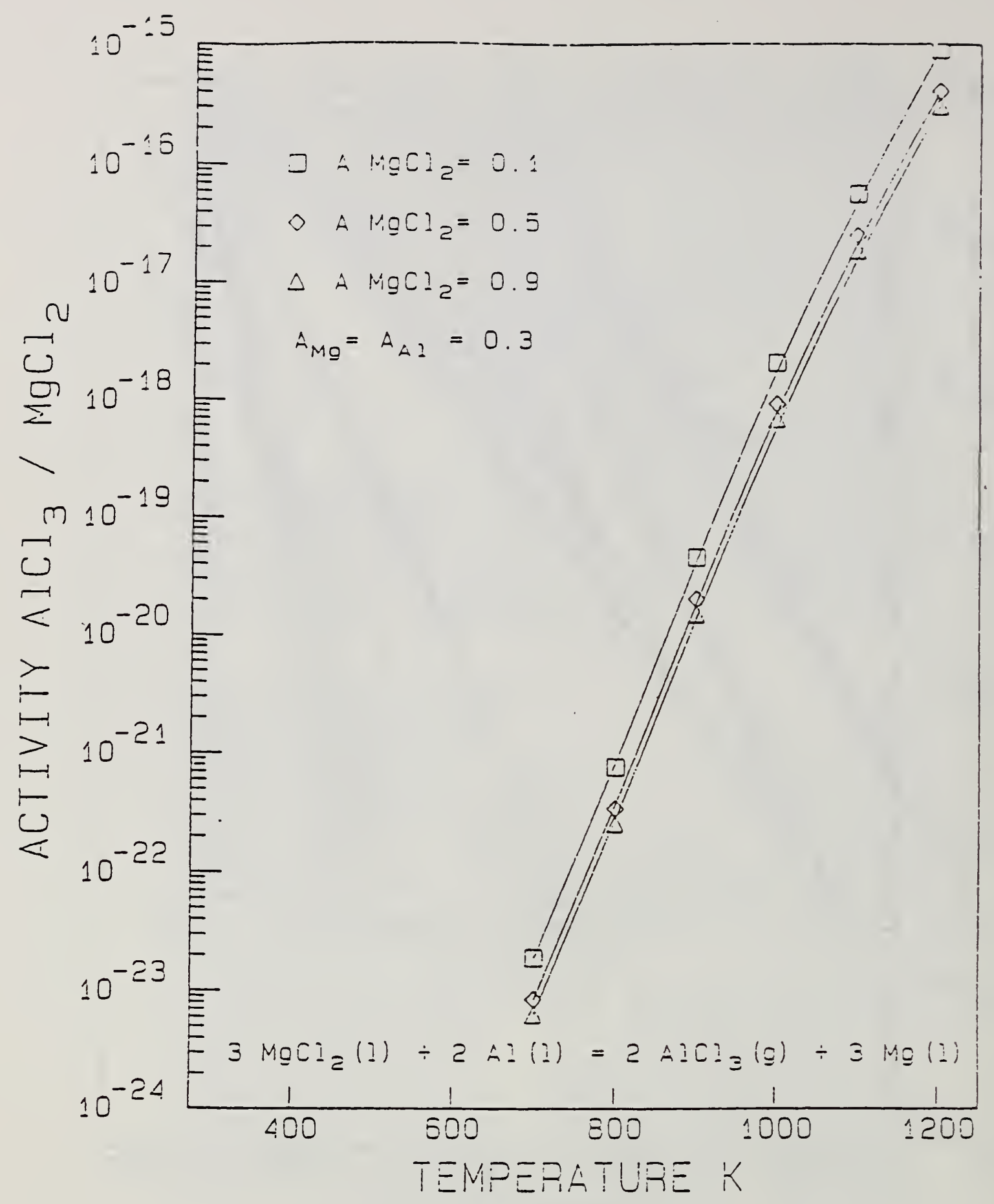

Figure 26. Calculated chemical equilibria of ( $\mathrm{Mg}$, Al) chlorides formed by reaction with LiMgAl alloy. 


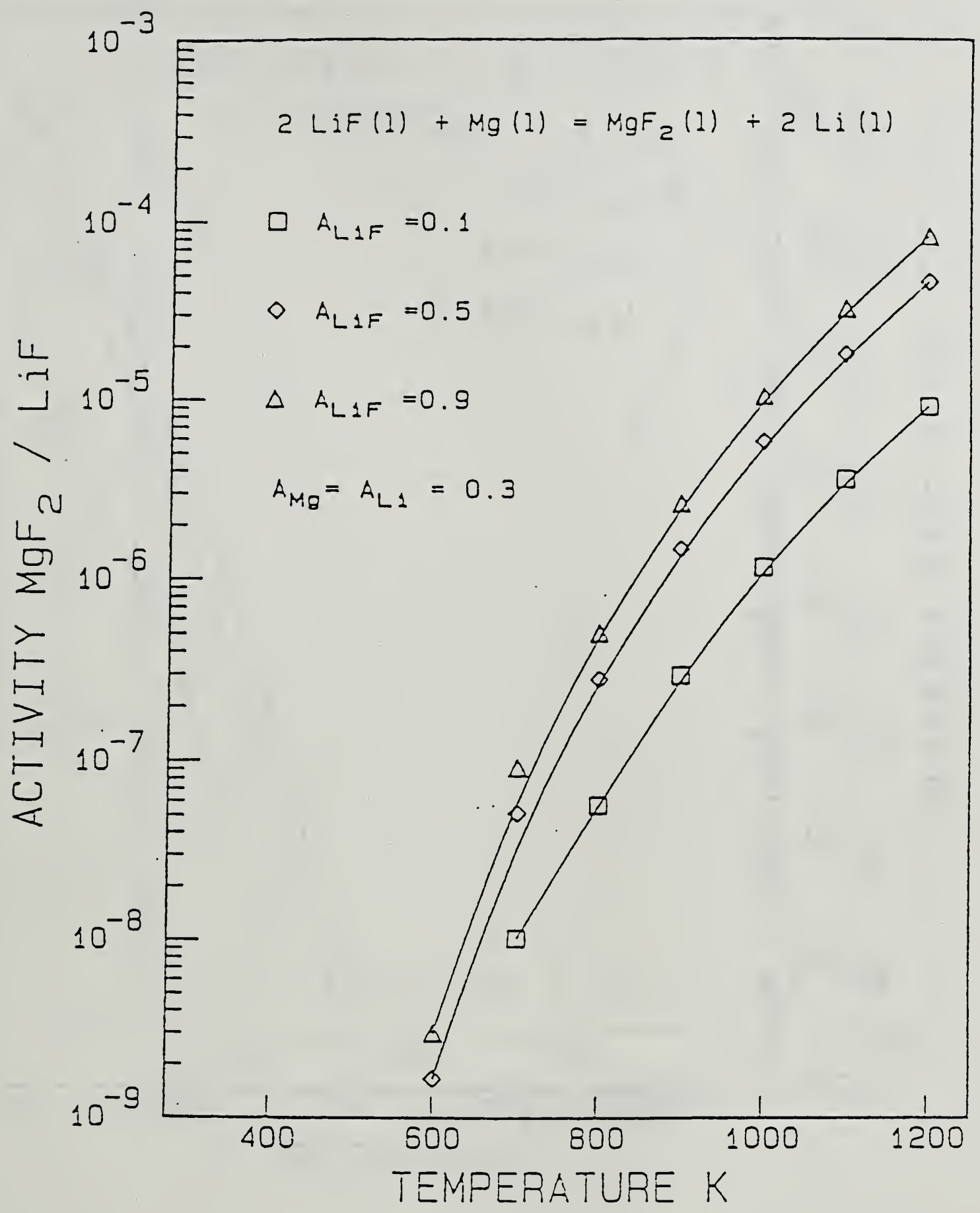

Figure 27. Calculated chemical equilibria of ( $\mathrm{Li}, \mathrm{Mg}$ ) flourides formed by reaction with liMgAl alloy. 


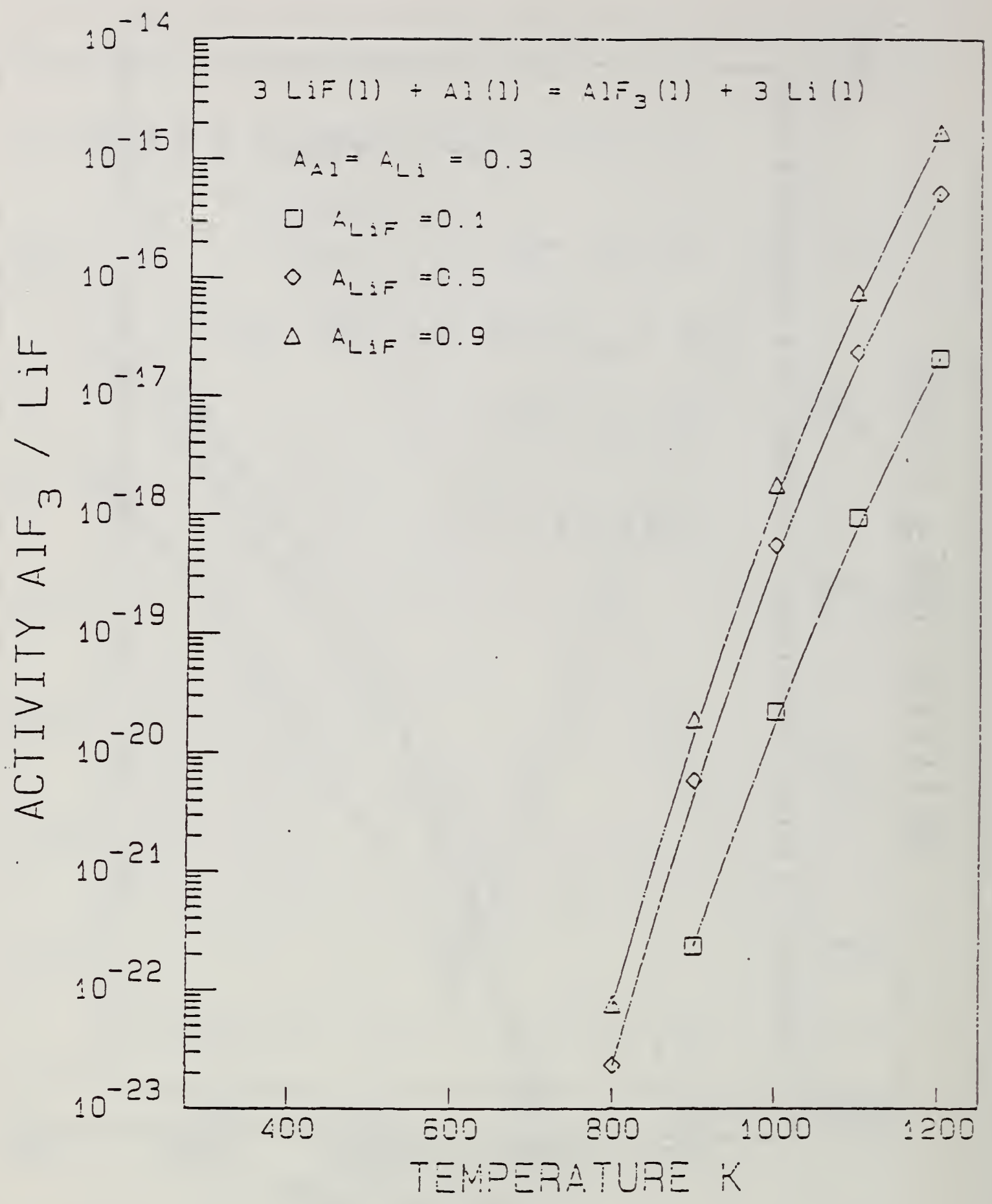

Figure 28. Calculared chemical equilibria of (Ii, Al) flouricies formcd by reaction with IiMgal alloy. 


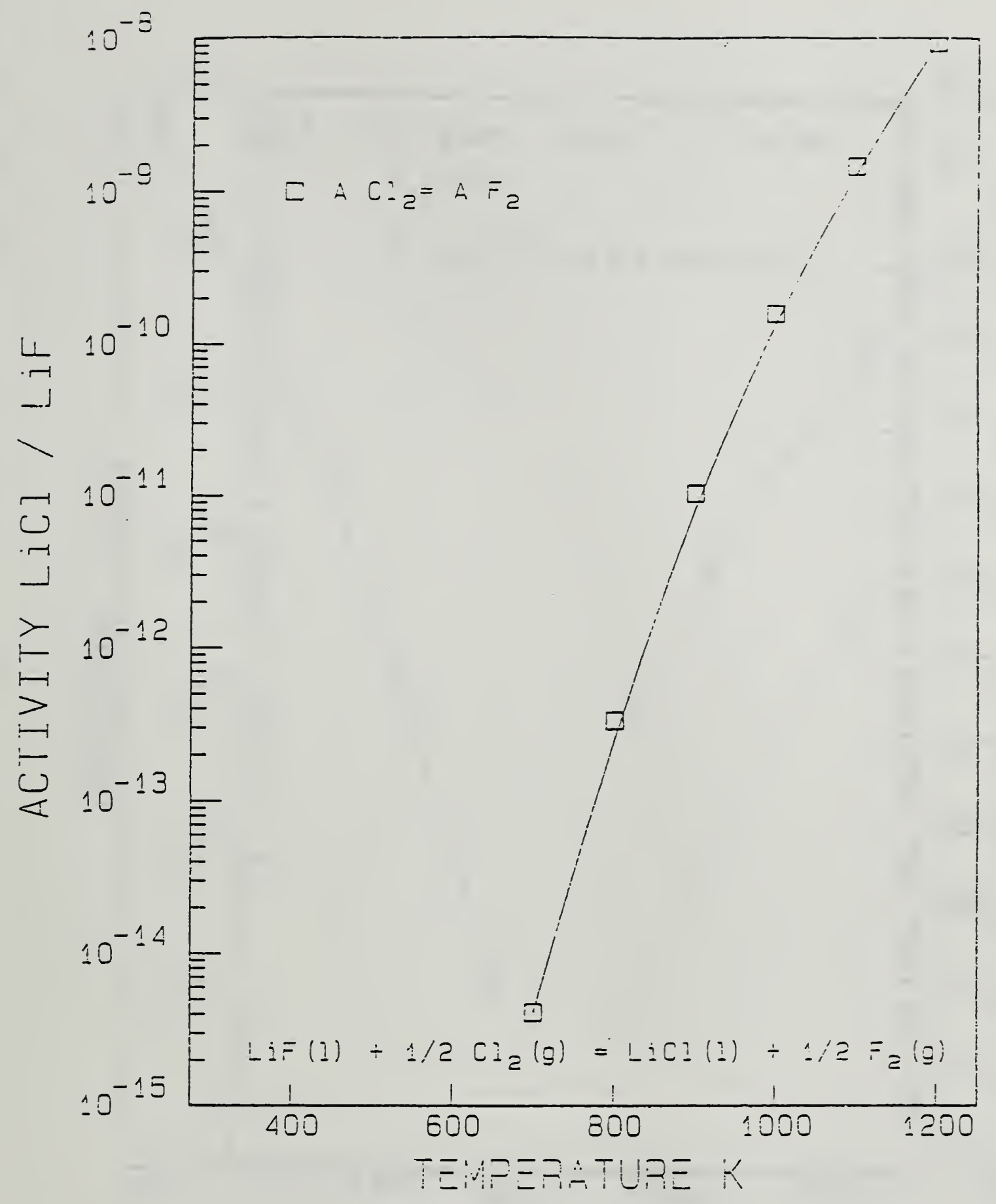

Figure 29. Calculated partitioning of flourine in the lithium molten salt phase. 


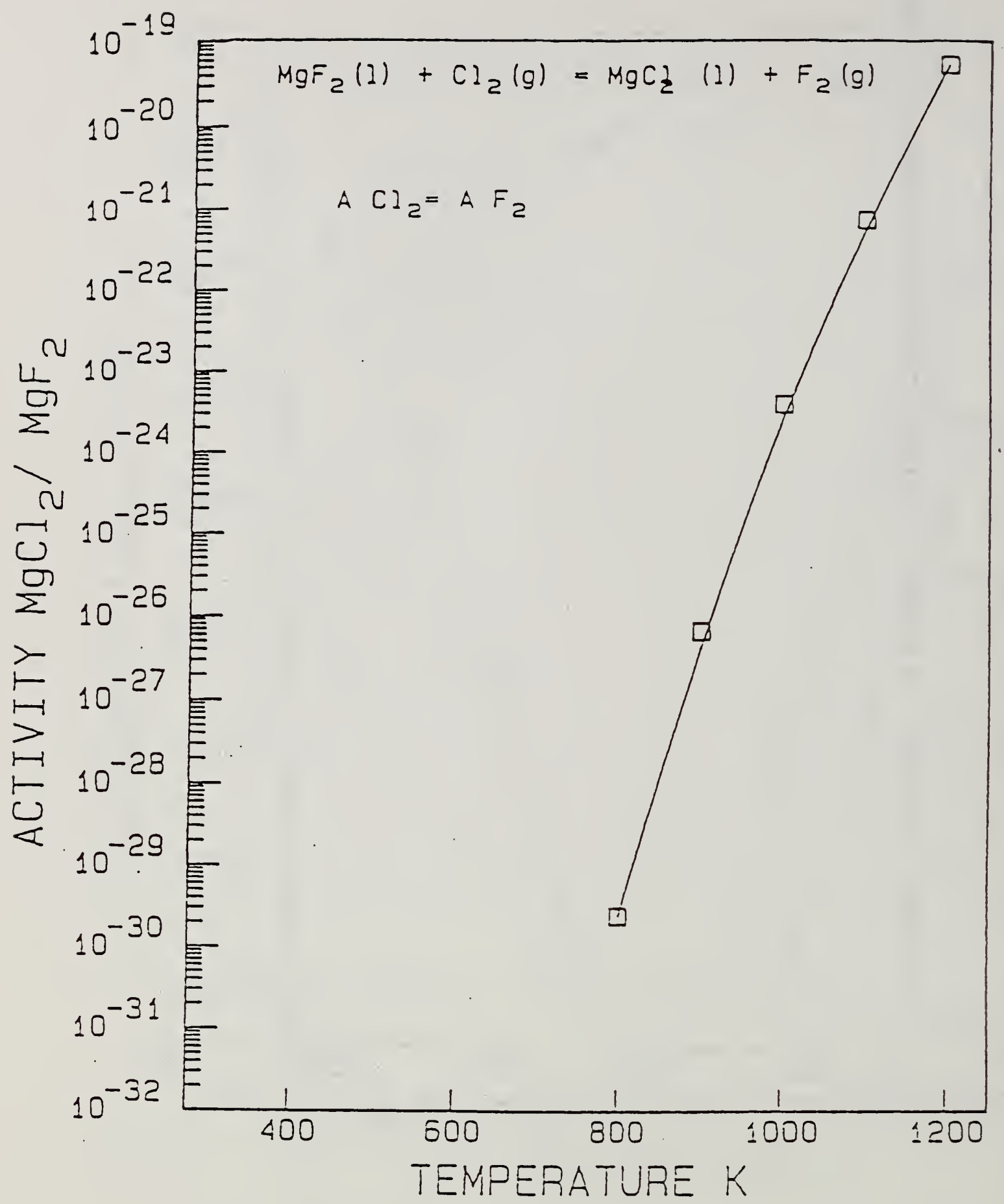

Figure 30. Calculated partitioning of flourine in the magnesium molten salt phase. 


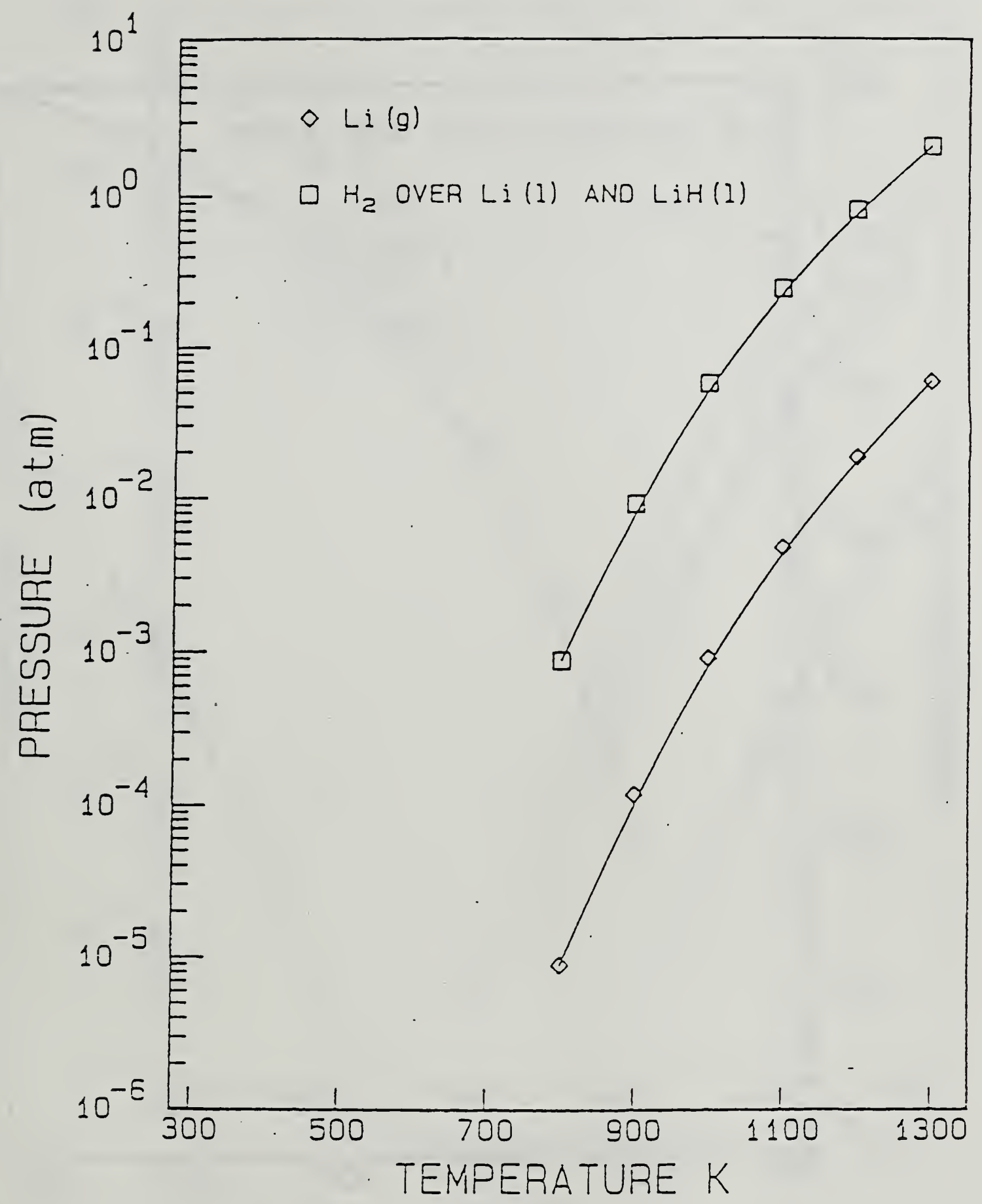

Figure 31. Calculated vapor pressures over molten lithium and over a $\mathrm{Li}+\mathrm{LiH}$ mixture. 


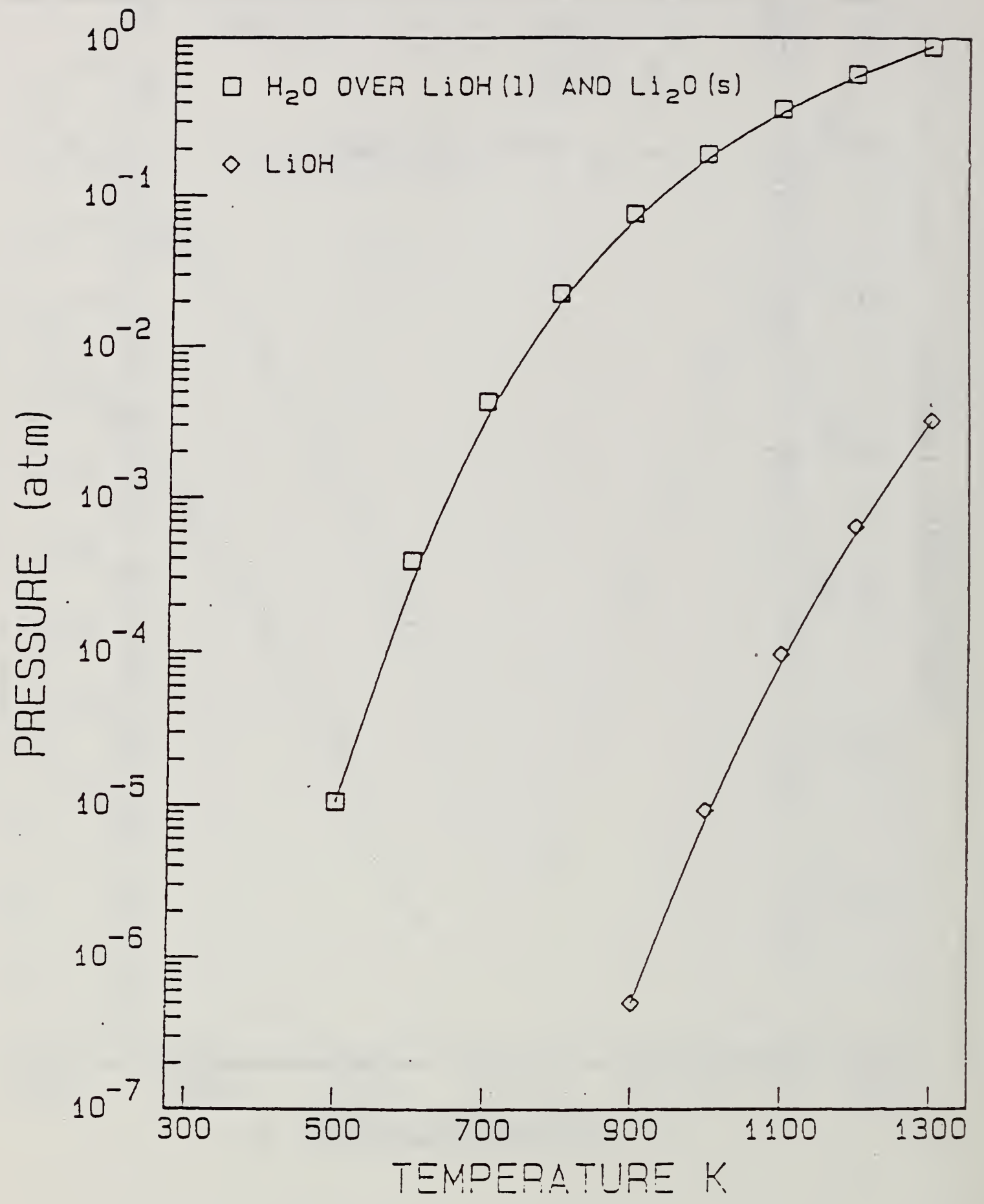

Figure 32. Calculated vapor pressures over $\mathrm{LiOH}$ and over a $\mathrm{LiOH}+\mathrm{Li}_{2} \mathrm{O}$ mixture. 


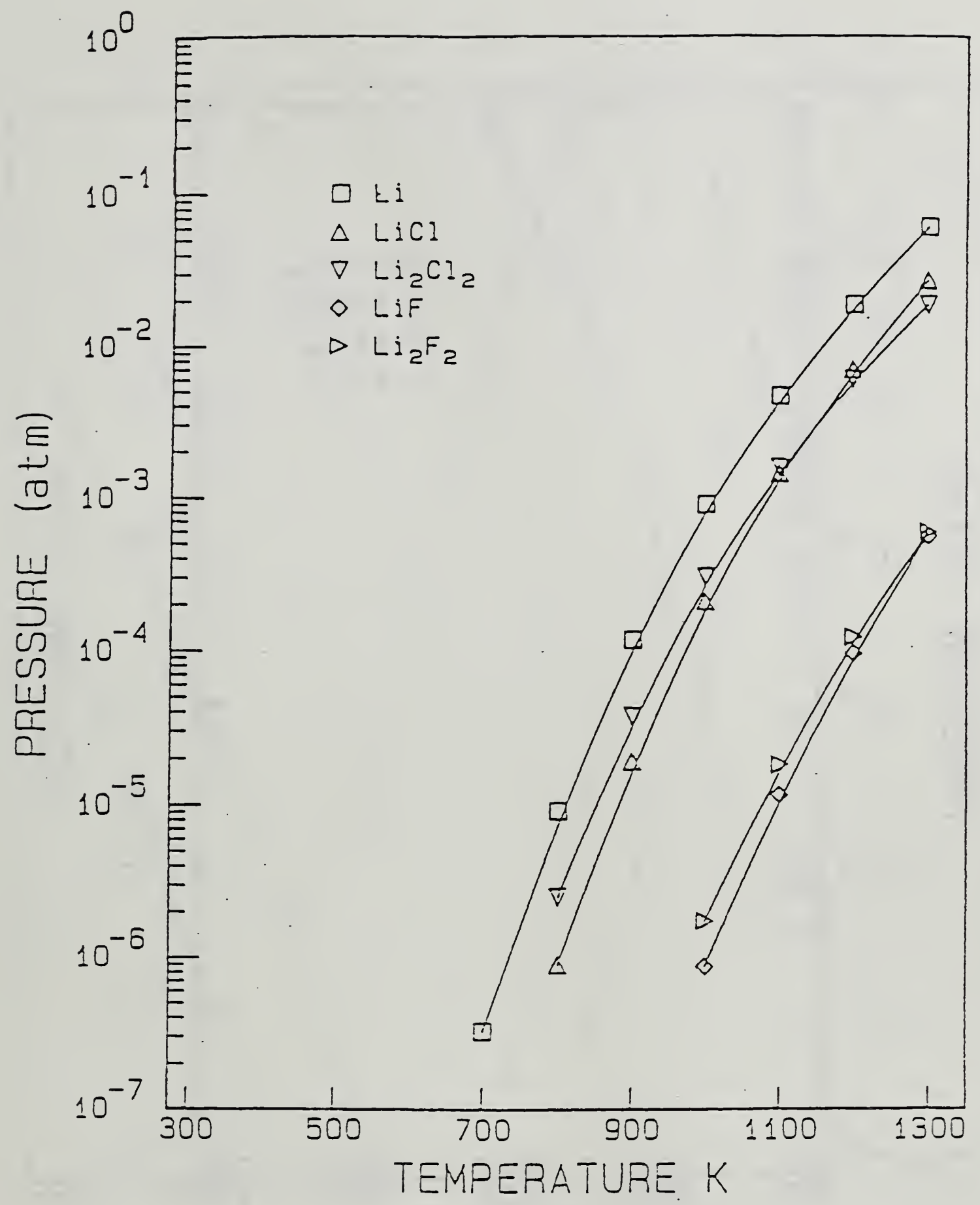

Figure 33. Calculated partial pressures of lithium species over their respective condensed phases. 


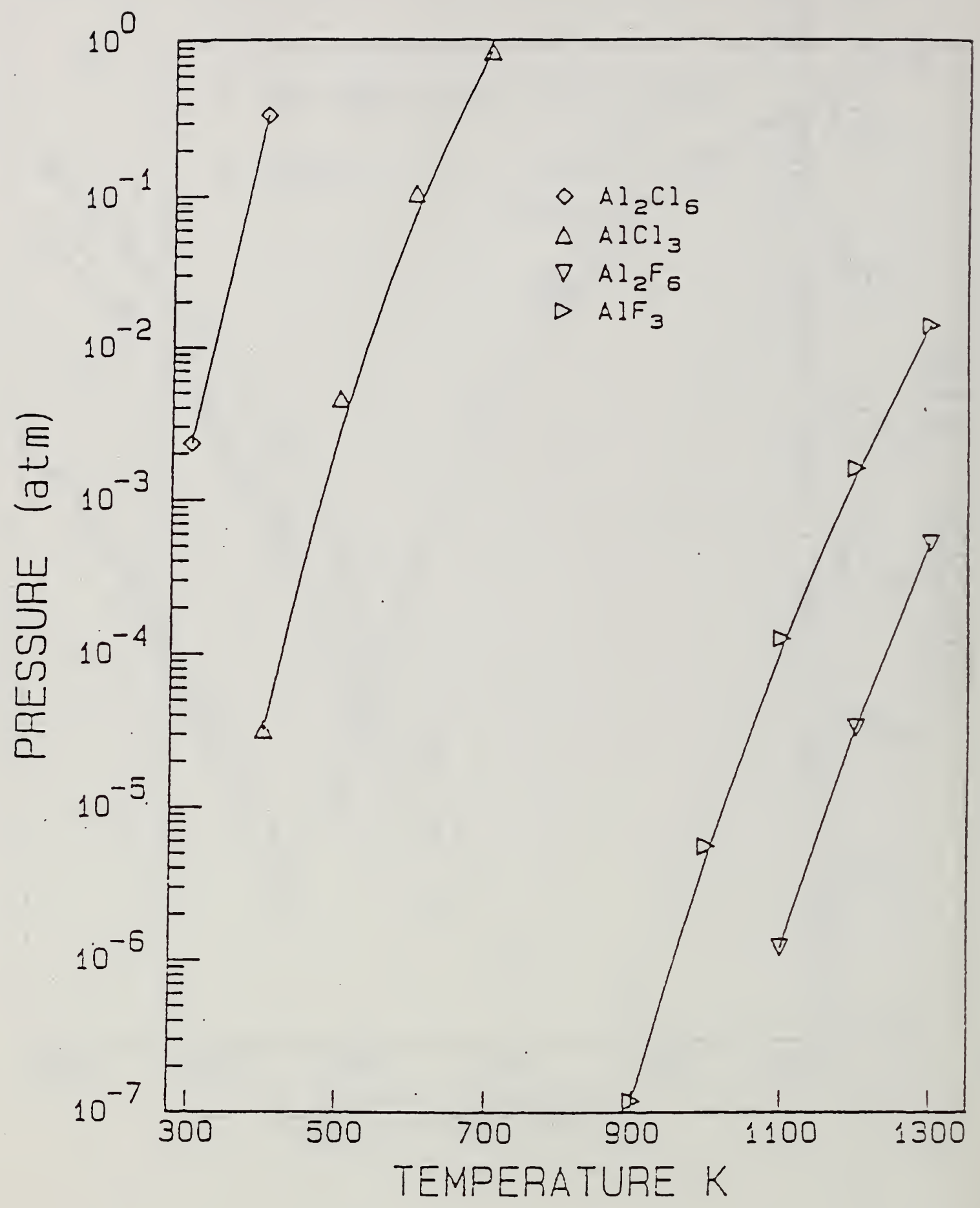

Figure 34. Calculated partial pressures of aluminum species over their respective condensed phases. 


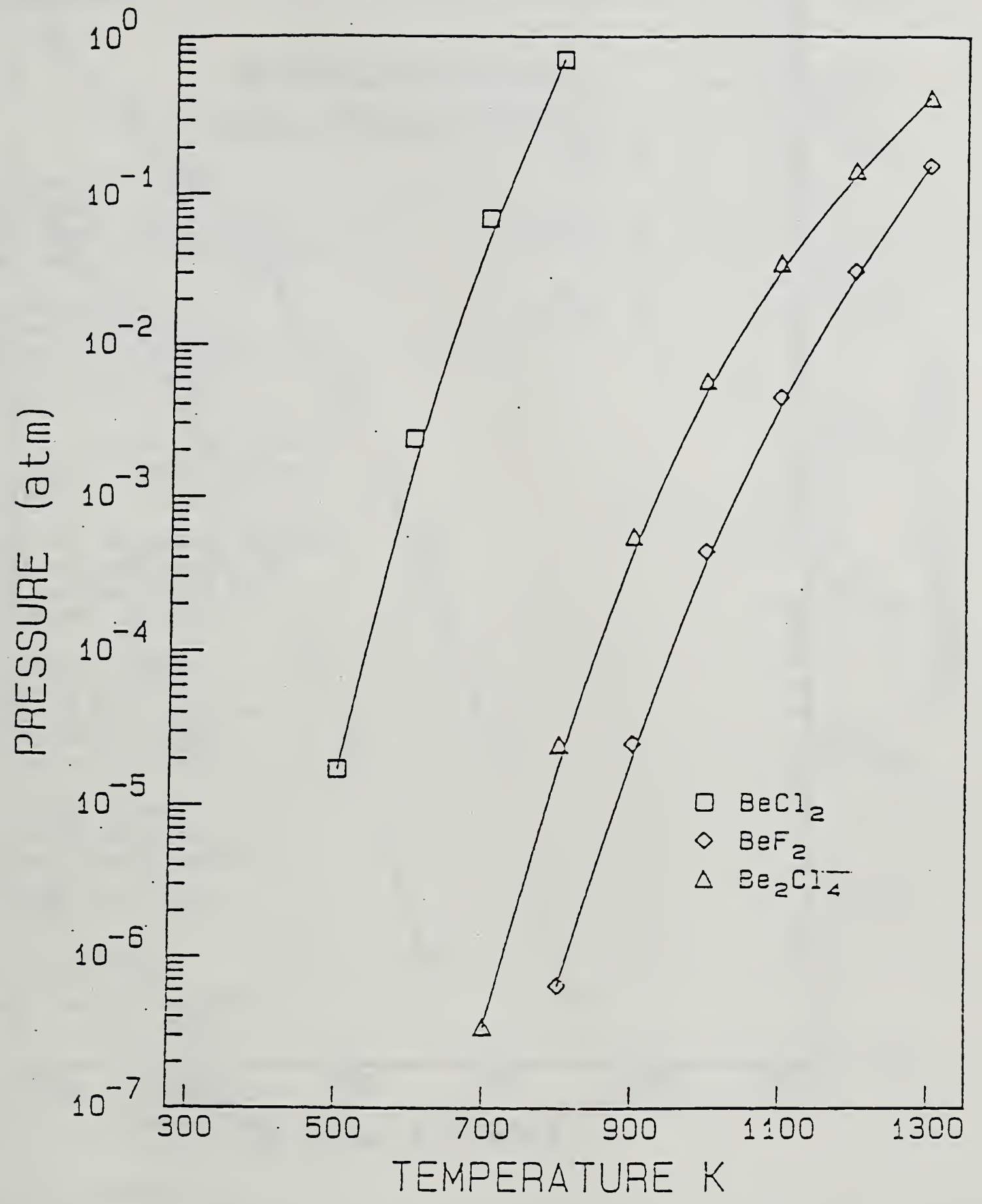

Figure 35. Calculated partial pressures of beryllium species over their respective condensed phases. 


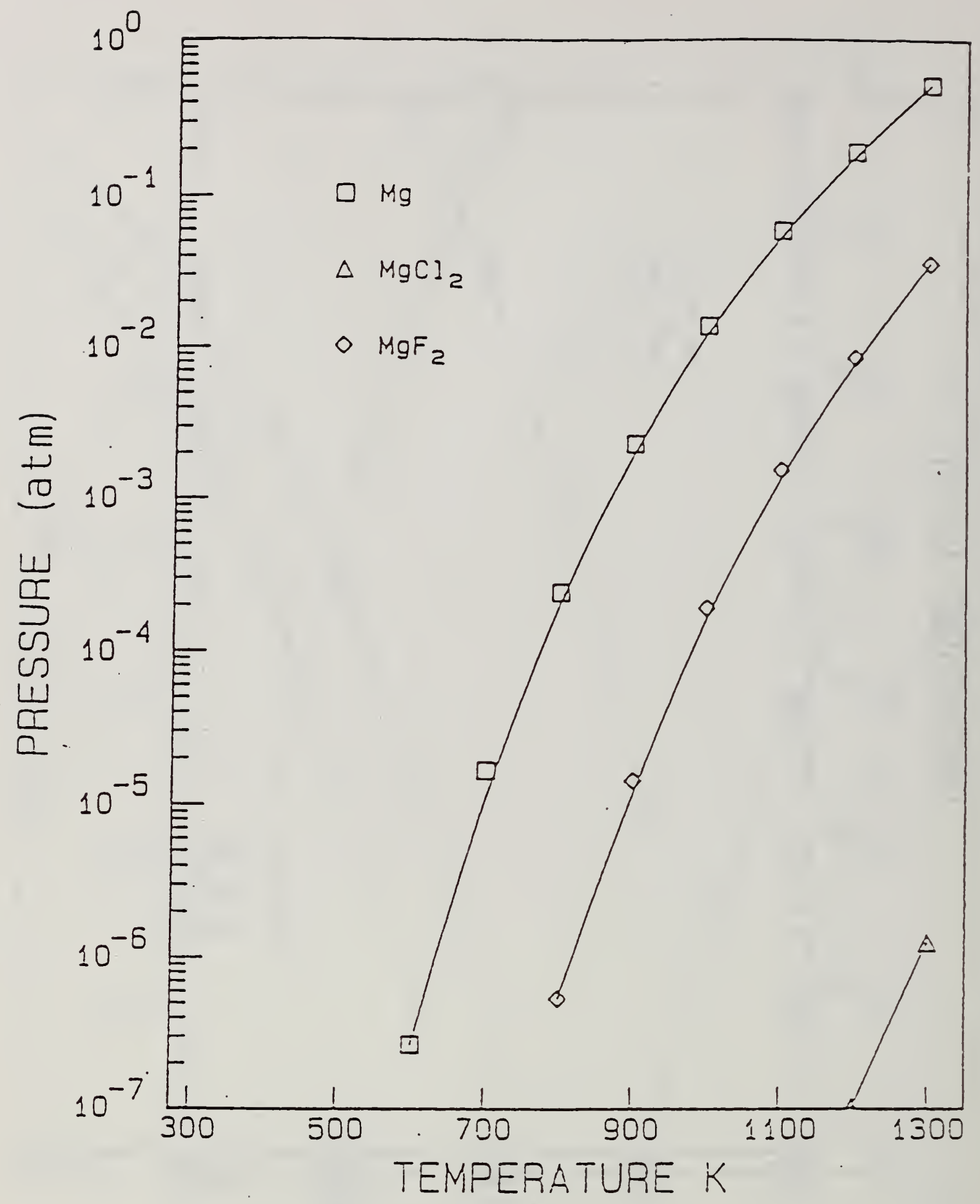

Figure 36. Calculated partial pressures of magnesium species over their respective condensed phases. 
ONR REPOFT DISTRIBUTION LIST

CLOSED, LIOUID METAL COMSUSTIOH
One copy except

as noted

Dr. Lynn A. Parneil

Code 6341

Naval Ocean Systems Center

San Diego, Califorria 92152

Dr. Richard Miller

Mechanics Division

Office of Naval Research

$800 \mathrm{~K}$. Quincy Street

Arlington, VA. 22217

Defense Documentation Center

Quilding 5, Cameron Siztion

fiexandria, l'a. 22314

Technical Information Division

liaval Research Laboratory

4555 Overlook Avenue S'

Washington, DC 20375

Or. Jerry A. Smith

Chemistry Division

Office of Naval Research

$800 \mathrm{~K}$. Quincy Street

Arlington, Ví. 22217

Dr. Albert 0 . Hood

Technology Programs

Ofifice of Nieval Research

800 N. Quincy St.

Arlington, VA. 22217

Dr. H.H. Carhara

Combustion a Fuels

Niaval Research Laboratory

h'ashington, $D C 20375$

Professor Allen Fuhs

Depariment of Aeronzutics

Naval Post Eraduaie School

Monierey, Celifornic $9: 9: 3$

Division Director

Engineering and heapons

US liaval ACademy

Annapolis, Maryiand $2 ! 402$

Mr. Fanncis J. Romano

Code 63R3

Niaval Sea Sysiems Comend

h'rshington, DC 20363 
One copy except as noted

Mr. Norman D. Hubele

Fluidic Systems, MS 1301-RR

Garrett Pneumatic Systems Dirision

2801 East Washington St.

Phoenix, Arizona 85034

Or. Hugh H. Darsie

Advanced Technology Group

Sunstrand Energy Systems

4747 Harrison Avenue

Rockford, Illinois 61101

Professor Gerard M. Faeth

Department of Aerospace Engineering

University of Michigan

Ann Arbor, Michigan 48109

Or. Dan H. Kiely

Power \& Energy Group

The Pennsylvania State University

Applied Research Laboratory

P.0. Box 30

State College, Pennsylvania 16801

Professor Darryl E. Metzoer

Department of Mechanical \&

Aerospace Engineering

Arizona State University

Tempe, Arizona 85281

Dr. Dae H. Cho

Reactor Analysis \& Safety Division

Argonne Nationial Laboratory

Argonne, Illinois 60439

Professor S.H. Chan

Department of Mechanical Engineering

The University of Wisconsin-Milwaukee

P.0. Sox 784

Milticukee, hisconsin $5 \$ 201$

Frofiessor Georce is. Erown

Uepariment of Mechanical Engineering

and Appiied Mechanics

University of Rhode island

Kinçston, Rriode $|s| a n d$ 02ES! 
One copy except

as noted

Professor A. Murty Kanury

Department of Mechanical Engineering

Oregon State University

Corvalitis, Oregon 97331

Professor Irvin Glassman

Department of Mechanical \& Aerospace Engineering

Engineering Quadrangle

Princeton University

Princeton, New York 08544

Professor Noman Chigier

Department of Mechanical Enginetring

Carnegie-Mellion University

pittsburgh, Pernsyivania $1521 ?$

Professor George Janz

Cogswell Laboratory, R306

Department of Chemistry

Rensselaer Polytechnic Institute

Troy, New York 1218!

Or. Leonard Leibowitz

Chemical Technology Division

Aroonne Rational Laboratory

9700 South Case Avenue

Argonne, Illinois 60439

Professor John Tarbell

104 Fenske Laboratory

Pennsylvania State University

University Park, Pennsyivania 1680 !

Professor Thomas E. Daubert

104 Fenske Laboratory

Pennsylvania State University

University State Park. Pennsyivania 16801

Or. J. Braunstein

Research Dirisicn

Oek ficọe Operazions

Dedartmient

Oak Ridge, iennessee 
Mr. Robert Tompkins

Code 36621, Bidg 126T

Naval Undemater Systems Center

Niewport, Rhode Island C284]

Mr. Maurice F. Murphy

Code R33, Room 4-1711

Naval Surface Heapons, White Oar.

Silver Spring. Maryland 20910

Or. Kurt Mueller

Code $8: 10$

Energetic Materials Division

Naval Surface Heapons Cenier. White Oak

Silver Spring. Maryland 20910

Dr. Earl Quendt, Jr.

Code 2704

David Taylor liaval Ship

Research and Development Center

Annapolis, M.D 21402

Mr. Richard Bloomouist

Code 2752

Davio Taylor hiaval Ship R\&D Center

Annapolis, Maryland 21402

Or. Lawrence P. Cook

Kigh Temperature Processes Group

Niational Bureau of Siandards

W'asningtor, DC 20234

Or. K. Lee

Research and Technology Department

Naval Suriace Heapons Center

Silver Spring, MD 20703 
4. TITLE AND SUBTITLE

Higb Temperature Chemistry of Stored Chemical Energy Reactions for Propulsion

5. AUTHOR(S)

L. P. Cook, E. R. Plante, D. W. Bonnel1, J. W. Hastie

6. PERFORMING ORGANIZATION (If joint or other than NBS, see instructions)

7. Contract Grant No.

\section{NATIONAL BUREAU OF STANDARDS \\ U.S. DEPARTMENT OF COMMERCE \\ GATTHERSBURG, MD 20899}

8. Type of Report \& Period Covered

9. SPONSORING ORGANIZATION NAME AND COMPLETE AODRESS (Street, City, Stote, ZIP)

Office of Naval Research

800 N. Quincy Street

Arlington, VA 22217

10. SUPPLEMENTARY NOTES

Document describes a computer program; SF-185, FIPS Software Summary, is attached.

11. ABSTRACT (A 200-word or less foctual summary of most significant information. If document includes a significant bibliogrophy or literoture survey. mention it here)

This report summarizes the results of a continuing study of the high temperature chemistry of stored chemical energy reaction systems. The eight fuel/oxidant reactions of interest (including several which are multistage) are: $\mathrm{Li} / \mathrm{H}_{2} \mathrm{O}, \mathrm{H}_{2} / \mathrm{O}_{2}, \mathrm{NaO}_{2} / \mathrm{H}_{2} \mathrm{O}, \mathrm{LiB} /$ $\mathrm{NF}_{3}$. Thermodynamic prediction of the products of three of these reactions has been corroborated by equilibrating postulated products at high temperature, while results from a fourth reaction require modification of the reaction scheme originally proposed. Mass spectrometric observations on the thermal decomposition of $\mathrm{ClO}_{3} \mathrm{~F}$ at elevated temperatures are presented. Thermogravimetric studies have been completed on the behavior of $\mathrm{Al}_{2} \mathrm{O}_{3}$ and $\mathrm{MgO}$ in the presence of $\mathrm{ClO}_{3} \mathrm{~F}$ and on the oxidation of molten aluminum droplets by $\mathrm{ClO}_{3} \mathrm{~F}$. The solid state phase transition in LiAl $\mathrm{O}_{8}$ has been studied by DTA. In the $\mathrm{ClO}_{3} \mathrm{~F}$-based reaction systems, substantial entry of flaorine into the product $\mathrm{LiAl}_{5} \mathrm{O}_{8}$ spinel phase is postulated.

Thermodynamic calculations have been completed to assess the importance of vaporization of reactant/product solids and liquids.

12. KEY WORDS (Six to twelve entries; alphobetical order: copitalize only proper nomes; ond separate key words by semicolons) $\mathrm{Al}_{2} \mathrm{O}_{3}$; aluminum; kinetics; Li 0 ; 1 ithium; magnesium; mass spectrometry; perchloryl flboride; phase equilibria; stored chemical energy reactions; thermal analysis;

13. AVAILABILITY

XX] Unlimited

For Official Distribution. Do Not Release to NTIS Order From Superintendent of Documents, U.S. Government Printing Office, Washington, D.C.
20402 .

14. NO. OF PRINTED PAGES

XX Order From National Technical Information Service (NTIS), Springfield, VA. 22161 


